\title{
Expedition 324 summary ${ }^{1}$
}

\author{
Expedition 324 Scientists $^{2}$
}

\section{Chapter contents}

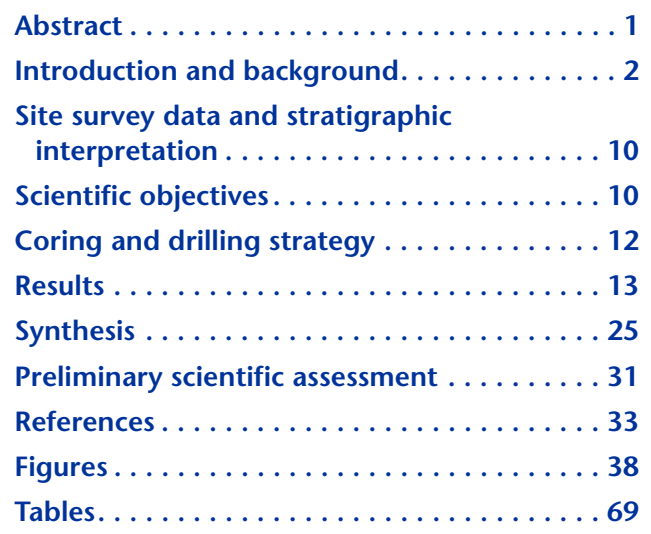

${ }^{1}$ Expedition 324 Scientists, 2010. Expedition 324 summary. In Sager, W.W., Sano, T., Geldmacher, J., and the Expedition 324 Scientists, Proc. IODP, 324: Tokyo (Integrated Ocean Drilling Program Management International, Inc.).

doi:10.2204/iodp.proc.324.101.2010

${ }^{2}$ Expedition 324 Scientists' addresses.

\section{Abstract}

Oceanic plateaus are giant volcanic features whose existence implies an extraordinary flux of magma from mantle to lithosphere. By understanding their formation, these large igneous provinces can be important indicators of fundamental processes of mantle convection and geodynamics. Although it is widely thought that oceanic plateaus arise from massive eruptions resulting from the arrival of a deep mantle plume head at the lithosphere, an alternative explanation is that plateau eruptions are related to decompression melting of unusually fusible mantle beneath fast-spreading ridges. Shatsky Rise was cored during Integrated Ocean Drilling Program Expedition 324 because it is a unique oceanic plateau, formed during the Late Jurassic and Early Cretaceous at a rapidly spreading triple junction, with characteristics that could be attributed to either model of formation. Shatsky Rise is also a monster volcanic construct whose formation style is poorly understood. The goal of Expedition 324 was to core the igneous rocks of Shatsky Rise and the sediments above to examine the age, physical volcanology, geochemistry, and tectonic evolution of the rise as well as the sedimentation history.

Five sites were cored and four were logged, with one site (U1346) on the summit of Shirshov Massif and two sites each on Ori (Sites U1349 and U1350) and Tamu (Sites U1347 and U1348) massifs. Basaltic lava flows were recovered at four of these sites and complement previous Ocean Drilling Program Site 1213 (south flank of Tamu Massif) in providing a record of lava flow emplacement on Shatsky Rise. Instead of lava flows, cores from Site U1348 recovered a thick sequence $(\sim 120 \mathrm{~m})$ of volcaniclastic sediments topped with shallow-water calcareous sandstones. Lavas recovered at Sites U1347 and U1350 are fresh enough to be suitable for high-quality radiometric dating and planned geochemical/isotopic studies. Although lavas from Site U1346 and U1349 were moderately to highly altered, it is expected that they will also provide important age information with suitable treatment and will be useful for most geochemical studies. Even though the volcaniclastic rocks of Site U1348 are highly altered, a single interval containing relatively fresh glass shards will provide valuable information on magma source characteristics.

Shatsky Rise lava flows occur primarily as packages of pillow basalt and massive inflation units, frequently interbedded with volcaniclastic sediment. The thickest massive inflation flows, up to 
23 m thick, occur on Tamu Massif at Sites 1213 and U1347. They are similar to massive flows cored on the Ontong Java Plateau (OJP) and found in continental flood basalt provinces. At Site U1347, the relationship of pillows and massive flows suggests magmatic cycles that began with the emplacement of massive sheet flows and waned with pillow lavas. Moreover, paleomagnetic inclination trends at both Sites 1213 and U1347 imply that little time passed between the emplacement of individual flows. The implication is that Tamu Massif concluded with massive, high effusion-rate eruptions. Massive flows are also found at Sites U1349 and U1350, on Ori Massif's summit and flank, respectively, but only two larger cooling units (1.9 and $3.2 \mathrm{~m}$ thick) were recognized at Site U1346, on the Shirshov Massif summit, otherwise consisting of many smaller pillow units. The massive flow units are thinner at Ori Massif than most flows penetrated on Tamu Massif. Moreover, Site U1350 geochemical and paleomagnetic inclination trends imply greater time and more eruptive variability. The simplest conclusion from the observed trends in lava flow style across the three main edifices of Shatsky Rise is that the average eruptions become smaller and less effusive from Tamu to Ori to Shirshov massifs.

Basement rocks recovered from the two summit sites (U1346 and U1349) on Shirshov and Ori massifs show the most severe alteration, apparently from both low and moderately high temperature fluidrock interaction, the latter especially for Site U1349. In contrast, lavas cored on the deeper flanks of the massifs show evidence of only light to moderate lowtemperature alteration. Although these highly altered sites represent only two individual cases, this dichotomy suggests that alteration and fluid-rock interaction was more intense on plateau summits. Apparently, the summits were a focus of heat and water circulation. Rocks at the flank sites (1213, U1347, and U1350) were apparently affected by lesser fluid flow and temperatures. Lavas at these sites seem to have been rapidly paved over by subsequent flows and thereby sealed from extensive seawater contact/ circulation.

Several sites attest that volcanic debris is more important on Shatsky Rise than anticipated. A significant portion $(\sim 40 \mathrm{~m})$ of the Site U1349 section, located on a summit ridge on Ori Massif, consists of volcaniclastic breccia. Site U1348, which is situated on a buried volcanic high on Tamu Massif, yielded a succession consisting entirely of volcaniclastic material, mainly hyaloclastic sediment. In addition, volcaniclastic sediments were found at Sites U1346 and U1347. These observations indicate that volcaniclastic eruptions made an important contribution to the formation of Shatsky Rise, especially on the higher, shallower parts of the volcanoes.

Shipboard geochemical data show that the lava flows consist of variably evolved tholeiitic basalt. Site U1347 and U1350 lavas, least affected by alteration, have broad similarities with Site 1213 basalts and display compositional ranges overlapping those of OJP basalts and mid-ocean-ridge basalt (MORB), albeit more with the latter. Samples from Site U1347 and many samples from Site U1350 resemble enriched-type MORB (E-MORB). A broad generalization is that Shatsky Rise basalts are slightly enriched in incompatible elements compared to normal MORB (N-MORB). This suggests a mantle source slightly richer in the more incompatible elements than $\mathrm{N}$ MORB source mantle and/or that Shatsky Rise magmas formed by slightly lower degrees of partial melting and possibly in the presence of residual garnet. Alteration-resistant element ratios indicate that basalts from Sites U1346, U1348, and U1349 are also tholeiites. Site U1349 basaltic flows appear to represent significantly less differentiated magmas than those recovered from other sites and have similarities to picritic Ontong Java Plateau basalts (i.e., the high-Mg Kroenke type).

Multiple lines of evidence indicate that Shatsky Rise volcanoes had summits at or above sea level. Benthic foraminifers and/or sediment facies at all sites except Site U1350 (a lower flank site) show evidence of shallow-water deposition. Lavas at Site U1349 have alteration and flow structures consistent with subaerial eruption and weathering, as well as intercalations of shallow-water sediments (e.g., oolites). Most of the volcaniclastic deposition at Site U1348 occurred below sea level, but the succession was topped with shallow-water sediment. Two of the sites showing evidence of shallow-water deposition (Sites U1347 and U1348) are significantly downslope from today's highest points of basement level on Tamu Massif, implying that the summit was a large island. Taken together, evidence from Expedition 324 strongly implies that during Jurassic and Cretaceous times, Shatsky Rise was an archipelago of large volcanic islands.

\section{Introduction and background}

Knowledge about large igneous provinces (LIPs) has played a fundamental role in shaping the prevailing view of mantle geodynamics, that of largely platedriven flow in the upper mantle punctuated by rising, thermally driven plumes from the lower mantle (e.g., Davies, 1992). The largest LIPs, which include the oceanic plateaus, continental flood basalts, and volcanic passive margins, reach volumes of several 
$10^{6}$ to several $10^{7} \mathrm{~km}^{3}$ and are apparently the product of relatively short lived, massive magmatic episodes that represent the largest nonridge volcanic process on Earth (e.g., Coffin and Eldholm, 1994). In terms of magma flux, volume, and extent, such LIPs dwarf even the most prodigious present-day hotspots, such as Iceland and Hawaii. Magma production rates for the largest LIPs rivaled or even surpassed that of the global mid-ocean ridge system for short periods of time (e.g., Tarduno et al., 1991; Duncan and Richards, 1991; Mahoney et al., 1993; Coffin and Eldholm, 1994). Moreover, because many of the largest LIPs formed during the Mesozoic, they may represent a mantle convection regime different from that of the ridge volcanism-dominated Cenozoic (e.g., Stein and Hoffman, 1994; Machetel and Humler, 2003).

A widely accepted explanation for plateaus and continental flood basalts is the plume head hypothesis, which posits large (several hundred to $\sim 2000 \mathrm{~km}$ in diameter), bulbous, primarily thermal diapirs that are created at depth in the mantle, probably within the core/mantle boundary zone, and rise toward the surface, causing cataclysmic volcanism when they impact the lithosphere (e.g., Richards et al., 1989; Griffiths and Campbell, 1990). Similar to the related plume hypothesis for volcanism at hotspots (Morgan, 1972, 1981; Sleep, 2007), the plume head hypothesis has been accepted by many scientists because it provides a simple framework that seems to tie together many observations. Moreover, the plume head phenomenon occurs naturally in numerical and laboratory experiments, given appropriate rheologic conditions (e.g., Whitehead and Luther, 1975; Griffiths and Campbell, 1990, 1991). The trouble is that there is currently no unequivocal geological evidence proving that the plume head mechanism has operated within Earth. Many existing data are only indirect indicators of eruptive rate and magmatic volume and could be explained by alternative hypotheses. Ongoing debate about the number, characteristics, and even existence of mantle plumes (e.g., Smith and Lewis, 1999; Anderson, 2001, 2005; Foulger, 2002, 2007; Courtillot et al., 2003; Sleep, 2003; Foulger and Natland, 2003; DePaolo and Manga, 2003) makes it desirable to consider alternative explanations for plateaus. Because oceanic plateaus are arguably the most direct expression of mantle plume heads (in contrast to continental LIPs, whose magmas have passed through continental lithosphere), understanding oceanic plateau formation is thus critical to understanding mantle geodynamics.

In order to address the plume head versus alternative hypotheses, it is necessary to study a plateau for which the relation of the plateau to contemporaneous mid-ocean ridges is known. Unfortunately, this condition is not met for plateaus formed during the Cretaceous Normal Superchron (aka., Cretaceous Quiet Period)-like the Ontong Java, Manihiki, and Kerguelen plateaus-because of the lack of magnetic reversals and thus linear seafloor magnetic anomalies to mark the locations of spreading ridges. Shatsky Rise, located in the northwest Pacific (Figs. F1, F2), is the only large intraoceanic plateau formed at a time of magnetic reversals. Contemporaneous magnetic lineations exist around and within the plateau, providing a framework that allows the development of a tectonic model (Nakanishi et al., 1999; Sager et al., 1999). This model is currently based on geophysical inferences with little geological evidence from sampling.

Shatsky Rise is also unique because it has characteristics that suggest both plume head and ridge-controlled origins (Sager, 2005). The plateau's size, morphology, apparent eruption rate, and age progression are consistent with a plume head origin (Sager and Han, 1993; Nakanishi et al., 1999; Sager et al., 1999; Sager, 2005). In contrast, the plateau formed at a triple junction during a time of ridge reorganization, which suggests a link to ridge tectonics (Sager et al., 1999; Sager, 2005). Furthermore, Nd-Pb-Sr isotopic data for the few basalts cored and dredged from Shatsky Rise prior to Expedition 324 show a similarity to Pacific mid-ocean-ridge basalt (MORB), not the expected ocean island-type signature of a plume head eruption (Mahoney et al., 2005). Whether or not this MORB affinity is representative of all of Shatsky Rise or whether it characterizes only a few minor, late-stage magmas is a major unanswered question. However, the fact that existing data can be interpreted both ways suggests that this plateau is uniquely suited for testing plume head versus ridge tectonics models. Moreover, because several, perhaps many, oceanic plateaus formed at triple junctions (e.g., Winterer et al., 1976; Larson et al., 2002; Sager, 2005; Ishikawa et al., 2005; Smith, 2007), Shatsky Rise probably represents a significant class of ocean plateau, if indeed it is not representative of all.

\section{Plateau formation hypotheses}

Ocean plateaus are remote and difficult to sample. The resulting geological ignorance has led investigators to propose several plateau-formation mechanisms. One class of explanation calls upon anomalous behavior of tectonic plates, such as leaky transform faults (Hilde et al., 1976) or spreading ridge reorganizations (e.g., Anderson et al., 1992; Foulger, 2007). Another class invokes a mantle plume, usually as a plume head (Richards et al., 
1989; Mahoney and Spencer, 1991; Duncan and Richards, 1991; Coffin and Eldholm, 1994). A third type of mechanism explains plateau formation as a result of a large meteorite impact (Rogers, 1982; Roddy et al., 1987).

The mantle plume hypothesis has been widely accepted, in part because of known shortcomings or lack of development of other hypotheses. The meteorite impact hypothesis was first proposed before discovery of the Chicxulub impact crater (e.g., Hildebrand and Boynton, 1990) and several other large impact sites that were subsequently documented on the continents. Combined with a lack of evidence linking plateaus and impacts, the idea lay fallow for many years. However, this hypothesis has been revisited for the Ontong Java Plateau (Ingle and Coffin, 2004; Tejada et al., 2004) because evidence from the plateau does not neatly fit other hypotheses. Plate boundary mechanisms have gained only limited support, partly because they require the assumption of extensive regions of shallow, near-solidus asthenosphere that differ geochemically from the shallow asthenosphere that forms mid-ocean ridges, and partly because they may not be able to produce the volumes of magma required for the largest plateaus, such as the Ontong Java. Creating LIPs by cracks, even in a thick part of an oceanic plate, requires that a seemingly small perturbation unleash a massive volcanic event. Consequently, large volumes of anomalously warm asthenosphere or unusually chemically "fertile" (fusible) mantle, primed to undergo massive decompression melting, must be assumed (Anderson et al., 1992; Foulger, 2007).

Plume-based explanations for plateaus have been bolstered by a wide acceptance of the mantle plume hypothesis for oceanic islands. The idea that thermal (and perhaps chemical) instabilities from the lower mantle rise to the base of the plate and cause hotspot volcanism initially became popular because it provided a neat explanation for age-progressive volcanic chains (Wilson, 1963; Morgan, 1971, 1972; Glen, 2005; Anderson and Natland, 2005). As more ageprogressive seamount chains have been found, this explanation has been used repeatedly, with one result being an improbably large number of proposed plumes. In part, this problem stems from loose application of the plume definition. Recent reexamination of hotspots led Courtillot et al. (2003) and Anderson (2005) to conclude that only a small number fit the original plume concept, that of a thermal diapir originating at or near the core/mantle boundary. Instead, many hotspots, especially smaller ones, likely have shallower sources that may or may not be related to significant thermal upwelling.
The plume head hypothesis arose as an offshoot of the traditional plume hypothesis. It was observed experimentally that if viscosity conditions are appropriate, then perturbations in a gravitationally unstable fluid layer form large, bulbous heads that rise through the overlying fluid and that the heads are followed by tails of rising, lower-layer material (Whitehead and Luther, 1975; Richards et al., 1989; Griffiths and Campbell, 1990). Such models led to the idea that mantle plumes form near the core/ mantle boundary, begin with massive diapirs (plume heads) that rise through the mantle and are fed and followed by a narrow conduit of the same lowerlayer material (plume tail). Other versions of the plume-head model start plumes from a shallower level, which serves either as the primary source region (e.g., Allègre and Turcotte, 1985; White and McKenzie, 1989; Kellogg et al., 1999) or as a barrier to a lower-mantle plume head, which then creates an upper-mantle plume head by heating from below (Tackley et al., 1993). All of these hypotheses are similar in that they require large thermal (and/or chemical) anomalies that arise at depth and carry deep mantle material to the base of the plate.

Impingement of a plume head on the lithosphere is thought to lead to voluminous production of basaltic magma, forming an oceanic plateau or continental flood basalt, depending on the type of lithosphere (e.g., Richards et al., 1989; Campbell, 1998). Wide acceptance of this hypothesis rests on radiometric ages indicating that several flood basalts and plateaus were formed rapidly, on the ocean islandlike Nd-Pb-Sr-Hf isotopic signatures of many flood basalt sources, and on several long-lived seamount chains that can be traced back to a flood basalt province (e.g., Campbell, 1998). Recently, however, dating results from Ocean Drilling Program (ODP) Leg 183 on the Kerguelen Plateau and from the Caribbean LIP indicate a longer, more complex emplacement history than previously thought (Duncan, 2002; Coffin et al., 2002; Hoernle et al., 2004). Also, although Ontong Java basalts have an ocean islandtype isotopic signature and most of the plateau appears to have formed rapidly (at $\sim 120 \mathrm{Ma}$ ), an associated postplateau seamount chain is lacking; plus, the initial depth of much of the plateau was well below that predicted by the plume head model and the amount of posteruptive subsidence has been less than predicted (e.g., Mahoney et al., 2001; Fitton et al., 2004). The effect of such complications for the plume head model is still being sorted out.

One possible explanation for complex geologic histories for plumes comes from the thermochemical plume hypothesis, in which plume buoyancy arises 
not only from a difference in temperature between the plume and surrounding mantle, but also from density differences resulting from chemical composition (Davaille et al., 2003, 2005; Farnetani and Samuel, 2005; Lin and van Keken, 2006a, 2006b). The primary implications of this type of plume are that it may not behave as a simple thermal plume would, potentially having an extended residence in the lower mantle, perhaps stalling at intermediate mantle depths and produce less uplift than expected from a thermal plume, and having more than one pulse of flood basalt volcanism.

\section{Why study Shatsky Rise?}

During the middle 1990s, scientific ocean drilling studies focused on the Kerguelen and Ontong Java plateaus because they are by far the largest, most outstanding examples of LIPs. A serious limitation to understanding the origin of these two plateaus is that they formed mainly during the Cretaceous Long Normal Superchron, so their relationship to contemporaneous spreading ridges cannot be determined. Shatsky Rise is important because it is the only large oceanic plateau that formed during a time of magnetic reversals, and the magnetic lineations that run through the plateau (Fig. F3) imply that it formed at a triple junction. Knowledge of oceanic plateaus is still so rudimentary that we cannot be certain whether Shatsky Rise and Ontong Java Plateau, for example, formed by the same mechanism. Many other plateaus have formed at triple junctions (Sager, 2005), so Shatsky Rise probably represents a class of ridge-related plateaus, if not all ocean plateaus.

Although there are a dozen or so large oceanic plateaus, Shatsky Rise is unique in its setting and holds critical clues to understanding plateau formation. It is a high priority for study for a number of reasons.

- With an area of $\sim 4.8 \times 10^{5} \mathrm{~km}^{2}$ (about the same as Japan or California) and a total volume of $\sim 4.3 \times$ $10^{6} \mathrm{~km}^{3}$, Shatsky Rise is one of the largest ocean plateaus (Sager et al., 1999). Moreover, bathymetric ridges and lava geochemistry suggest Shatsky Rise and Hess Rise (Fig. F1) may have arisen from the same source (Bercovici and Mahoney, 1994), which would nearly double the magmatic output. Magmatism of this scale requires something significantly unusual about the physical and/or chemical state of the source mantle.

- The fact that Shatsky Rise formed during a time of magnetic reversals makes it easier to understand than any other large ocean plateau. Magnetic anomalies can be used not only to date the plateau and surrounding lithosphere, but also to understand how plateau morphology is related to ridge tectonics (e.g., Sager et al., 1999; Nakanishi et al., 1999).

- Morphology, apparent age progression, and magnetic lineations together indicate that the rise volcanism was spread out laterally, perhaps owing to rapid movement of the Pacific plate over the source mantle (Nakanishi et al., 1999; Sager et al., 1999). In contrast, the volcanic record of larger plateaus formed on a more slowly moving plate (e.g., Ontong Java Plateau) may mainly consist of a vertically stacked pile. Therefore, the tectonic and geochemical evolution of Shatsky Rise is easier to address through drilling (i.e., shallow holes distributed laterally).

- Shatsky Rise formed at a ridge-ridge-ridge triple junction of rapidly spreading ridges; consequently, the lithosphere was young and thin, so lithospheric contamination of magmas should be minimal.

- Because of its location exactly along the track of a migrating triple junction and the fact that it appears to share both ridge and plume characteristics, Shatsky Rise is uniquely suited to testing plume head versus ridge-controlled hypotheses of plateau genesis.

Why was drilling required on Shatsky Rise? Although the main edifices of Shatsky Rise have some basaltic outcrops, dredged samples of igneous basement suitable for geochemical and geochronological work have proven difficult to get and harder to study. Because of the Late Jurassic to Early Cretaceous age of the oldest part of the plateau, outcrops on these edifices have probably been exposed for long periods. All outcrops dredged to date are coated with thick ferromanganese oxide deposits that make basement rock recovery difficult. Likewise, all existing dredge samples are highly altered. Although dredged basalts were recovered during the 1994 site survey cruise, the samples are highly altered and did not produce reliable radiometric dates, even with modern techniques (M. Pringle, unpubl. data). Likewise, all but a very few samples were unsuitable for chemical or isotopic studies (Tejada, 1998; Tatsumi et al., 1998). In addition, the dredge sites were all promontories, ridges, and other high points that may not be representative of the main plateau-building lavas. In sum, the only way to obtain samples that can address the origin of Shatsky Rise is by drilling a series of holes across the plateau and recovering hundreds of meters of basement igneous rock.

\section{Prior research on Shatsky Rise}

By the late 1960s, it was known that Shatsky Rise is ancient because Early Cretaceous sediments were 
cored from its summit (Ewing et al., 1966). Although seismic refraction experiments have not yet imaged the Moho beneath the high parts of the plateau, they have revealed anomalously thick crust with a similar velocity structure to normal oceanic crust but several times thicker (Den et al., 1969; Gettrust et al., 1980). Seismic profiling showed that the tops of the rise edifices hold thick piles of pelagic sediments (up to $1.2 \mathrm{~km}$ ), whereas sediments on the rise flanks are thin or absent in places (Ewing et al., 1966; Ludwig and Houtz, 1979; Neprochnov et al., 1984; Sliter and Brown, 1993).

Several Deep Sea Drilling Project (DSDP) and ODP cruises have cored Shatsky Rise over a span of 32 years. In succession, DSDP Legs 6 (Sites 47-50), 32 (Sites 305 and 306), and 86 (Site 577) as well as ODP Legs 132 (Site 810) and 198 (Sites 1209-1214) cored atop the highest, southern massif of the rise (Tamu Massif) (Fig. F2). Many of the holes had only shallow penetration. Drilling during Leg 32 probed deep into the sedimentary cap, recovering Berriasian (earliest Cretaceous) sediments $\sim 50 \mathrm{~m}$ above the expected level of basement at Site 306 (Fig. F2). This finding was significant because it implied that Tamu Massif formed during latest Jurassic or earliest Cretaceous time. Coring during ODP Leg 198 recovered sediments from all three of the Shatsky Rise massifs (Shipboard Scientific Party, 2002a), including Ori Massif (Site 1208) and Shirshov Massif (Site 1207). At both of these massifs, only the upper part of the sedimentary section was cored, reaching Late Cretaceous sediments. Igneous basement has been reached only twice. During Leg 6, drilling stopped at the top of supposed basement at Site 50, recovering only a few pebbles of basalt, perhaps from a basal conglomerate (Fischer, Heezen, et al., 1971). At Site 1213 on the southwest flank of Tamu Massif (Fig. F2), a $46 \mathrm{~m}$ section of slightly altered basaltic flows or sills intruding earliest Berriasian sediments (Shipboard Scientific Party, 2002b) was cored. These basalts produced the first reliable radiometric date for Shatsky Rise, as well as valuable chemical and Nd-PbSr isotopic data (Mahoney et al., 2005).

Magnetic lineations mapped in the northwest Pacific revealed that Shatsky Rise sits at the confluence of two lineation sets, the northeast-trending Japanese lineations and the northwest-trending Hawaiian lineations (Fig. F3) (Larson and Chase, 1972; Hilde et al., 1976). This circumstance indicates that the plateau formed at a triple junction separating the $\mathrm{Pa}$ cific, Farallon, and Izanagi plates (Larson and Chase, 1972). Subsequent studies revealed that the triple junction jumped repeatedly during the time it occupied the location of the rise and that it must have been kinematically unstable to follow the path of the rise (Sager et al., 1988, 1999; Nakanishi et al., 1999). Furthermore, age constraints (Cretaceous sediments and the Site 1213 radiometric date), seismic stratigraphy, and isostatic compensation all indicate that the age of the rise is near that of the adjacent seafloor (Sager et al., 1999), implying that the triple junction and rise formation are linked. Current thought is that a plume head is the link-a source of heat, uplift, and volcanism that both created the rise and captured the triple junction (Sager et al., 1988, 1999).

Magnetic data were also instrumental in supporting the idea that Shatsky Rise formed from a plume head. Sager and Han (1993) postulated that the rise formed rapidly, based on modeling of the magnetic anomaly over Tamu Massif. They noted that the magnetic anomaly implies a mainly reversed polarity, in turn implying that most of the edifice may have formed during a single interval of reversed polarity. With simple calculations using the massif volume and an estimate of the duration of the single polarity period, the authors inferred that the massif formed with an eruption rate similar to those of several large flood basalts $\left(\sim 1.8 \mathrm{~km}^{3} / \mathrm{y}\right)$.

More recent analyses have refined and expanded these conclusions. Paleomagnetic analysis of Site 1213 basalt samples gives inclination values that are most consistent with a reversed magnetic polarity (Tominaga et al., 2005). Furthermore, the mean ${ }^{40} \mathrm{Ar} /$ ${ }^{39} \mathrm{Ar}$ age of two basalt samples is $144.6 \pm 0.8 \mathrm{Ma}(2 \sigma)$ (Mahoney et al., 2005), a value indistinguishable from the age of the Jurassic/Cretaceous boundary $(145.5 \mathrm{Ma})$ and which correlates with magnetic Anomaly M19 in the Gradstein et al. (2004) timescale. This result limits the formation of much of the Tamu Massif to between Anomalies M21 and M19, a period of 1.5 m.y. If Tamu Massif formed during a single polarity interval, it is likely either M20 or M19, with durations of 0.4 and 0.75 m.y., respectively. Assuming the volume of the massif between Anomalies M21 and M19 formed in 1.5 to 0.4 m.y. (and making the conservative assumption that it formed on existing [very young] $7 \mathrm{~km}$ thick crust) implies volcanic emplacement at rates of 1.2 to 4.6 $\mathrm{km}^{3} / \mathrm{y}$ (Sager, 2005). Again, such values are in the range of estimates for several large continental flood basalts (e.g., Richards et al., 1989; Johnston and Thorkelson, 2000). Although these estimates are intriguing, they were made by very indirect means and require confirmation from radiometric ages of igneous basement samples, particularly from other locations on the rise. 


\section{Formation and tectonic history of Shatsky Rise}

Much of what is known about the tectonics of Shatsky Rise is based on the magnetic lineations that surround the plateau and in some places transect it (Fig. F3) (Sager et al., 1988; Nakanishi et al., 1989, 1999). The lineations range from M21 (148-149 Ma; polarity ages from Gradstein et al., 2004), bordering the southwest edge of the plateau, to M1 (125-128 Ma) at the northern tip of Papanin Ridge (Figs. F2, F3). Magnetic lineations have been mapped on the southeast flank of Tamu Massif, on flanks all around Ori and Shirshov massifs, in the basins between massifs, and all through Papanin Ridge (Fig. F3). Indeed, little of Shatsky Rise is without magnetic lineations. This observation led to the conclusion that the rise consists of three large edifices (Tamu, Ori, and Shirshov massifs) surrounded by lithosphere that is not greatly modified by plateau-building igneous activity (Sager et al., 1999; Nakanishi et al, 1999).

Shatsky Rise volcanism displays a progression in both age and volume along the trace of the triple junction. Rise volume decreases markedly with distance from Tamu Massif. This edifice has an estimated total crustal volume of $2.5 \times 10^{6} \mathrm{~km}^{3}$, whereas Ori and Shirshov massifs each have volumes of $0.7 \times$ $10^{6} \mathrm{~km}^{3}$. Papanin Ridge, at the north end of the plateau, has a volume of $0.4 \times 10^{6} \mathrm{~km}^{3}$, and the low ridge implies a low volcanic flux over a long period (Sager et al., 1999). Age also apparently decreases with distance from Tamu Massif, with the ages of the volcanic edifices close to those of the underlying lithosphere, as suggested by isostasy (Sandwell and MacKenzie, 1989). The 144.6 Ma date for the Site 1213 basalts is close to Anomaly M19, implying the bulk of the massif is Anomaly M19 age or older. Ori and Shirshov massifs must be younger than Tamu Massif because they reside on lithosphere younger than Anomaly M19. The youngest magnetic lineation beneath both Ori and Shirshov massifs is Anomaly M14 (140 Ma) and Papanin Ridge is underlain by Anomalies M10 to M1 (134-125 Ma). These observations are consistent with a northeastward-younging trend and volcanism following the triple junction path.

Magnetic lineations also show that a geometrically stable triple junction was moving northwest (in a Pacific plate reference frame) prior to Anomaly M22 time (Fig. F4). At Anomaly M21 time, the triple junction began to reorganize, with the Pacific-Izanagi isochrons showing a $30^{\circ}$ rotation, leading to microplate formation and an $800 \mathrm{~km}$ eastward jump of the triple junction to the location of Tamu Massif (Sager et al., 1988, 1999; Nakanishi et al., 1999). Afterward, until Anomaly M3 time (126 Ma) Shatsky Rise formed along the trace of the triple junction. During this time the triple junction jumped repeatedly-at least nine times (fig. 4 in Nakanishi et al., 1999). In addition, the main volcanic massifs have sides parallel to spreading ridges and transform faults. Together, these observations imply that rise volcanism was episodic and tied to ridge jumps (Sager et al., 1999).

\section{Prior geochemical data}

Chemical and isotopic data from igneous rocks are important for understanding the formation of ocean plateaus because such data provide key information on mantle sources and the conditions of magma genesis. For Shatsky Rise, such data are few. Only a small number of dredges have recovered basalt and all of the samples are highly altered, making the interpretation of geochemical data difficult. Tatsumi et al. (1998) concluded from Nb-Zr-Y data that a seamount within the rise has an ocean island-like composition similar to volcanoes of the South Pacific Superswell region, a finding that was interpreted as evidence for a plume head, lower mantle source. Whether or not superswell mantle sources come from the lower mantle is a subject of debate (e.g., Janney and Castillo, 1999; Lassiter et al., 2003; Natland and Winterer, 2005), but in any case the seamount is located in a basin between Tamu and Ori massifs (dredge D11; Fig. F2) and may have been formed after the rise itself.

In contrast, the Site 1213 basalts and two of the least altered dredge samples from the Tamu and Ori massifs (dredges D9 and D14; Fig. F2) display distinctly MORB-type isotopic characteristics (Mahoney et al., 2005). Age-corrected $\mathrm{Nd}$ and $\mathrm{Pb}$ isotope ratios of these rocks (e.g., $\varepsilon \mathrm{Nd}_{(\mathrm{t})}=+9.8$ to +8.6 ) are within the range for Pacific MORB and, despite seawater alteration effects, $\mathrm{Sr}$ isotope values (0.70269-0.70302) are also MORB-like (Fig. F5). Furthermore, the Site 1213 basalts have broadly MORB-like incompatible element patterns (Fig. F5). The plume head model predicts ocean island-like, not MORB-like, isotopic compositions (e.g., Campbell, 1998). Thus, at face value the few existing data do not support a plume head origin. However, the Site 1213 basalts are interspersed with sediments and located near the base of the sedimentary position of the site and the D9 and D14 dredge hauls sampled summit ridges; such latestage volcanic products may not be representative of the main plateau-building lava pile beneath.

\section{Sea level indicators}

A plume head should produce both dynamic and constructional uplift, implying that much of the area 
atop a plateau will initially be subaerial, particularly if formed on young lithosphere as with Shatsky Rise (e.g., Griffiths and Campbell,1990, 1991). For most of Shatsky Rise, evidence on basement paleodepth is lacking; however, a dredge from the upper flank (dredge D12; Fig. F2) of Tamu Massif recovered shallow-water fossils (rudist casts and corals) (Sager et al., 1999). Because the summit of Tamu Massif is higher, it must have been at or above sea level. Furthermore, a flat summit on Shirshov Massif (beneath the sediment cap) is seen in seismic profiles (Sager et al., 1999) and may indicate erosion by wave action. Thus, it appears likely that conditions during emplacement were sufficient to raise some areas of the rise above sea level. The anticipated recovery during Expedition 324 of sediments (including benthic fossils) resting immediately above the igneous basement may help to constrain paleodepths of the rise summits.

\section{What formed Shatsky Rise-a plume head or ridge tectonics?}

Shatsky Rise initially was attributed to plume volcanism because it is a very large, somewhat linear igneous construct (Sager et al., 1988; Nakanishi et al., 1989). Indirect evidence of a rapid eruption rate led to the proposal that the plateau formed from a plume head (Sager and Han, 1993; Nakanishi et al., 1989; Sager et al., 1999). At first blush, this explanation seems a good one. It predicts a trail of age-progressive volcanism tracking the motion of the plate over a nearly fixed source (Morgan, 1971, 1972). Shatsky Rise seems to fit this criterion because existing age constraints imply that the rise becomes younger northeastward. Aseismic ridges and seamount chains connect Shatsky Rise with Hess Rise, apparently continuing the eastward-younging trend. Moreover, a similarity of ages and trends between Shatsky and Hess rises and the Mid-Pacific Mountains even suggests that the volcanic tracks record the motion of the Pacific plate over nearly fixed mantle sources (Sager, 2005).

Arrival of a plume head should cause voluminous flood basalt-type magmatism, with peak volcanism occurring over a brief period ( $<2$ m.y. in several continental flood basalts), and significant amounts of initial uplift (e.g., Richards et al., 1989; White and McKenzie, 1989; Campbell and Griffiths, 1990; Duncan and Richards, 1991). As summarized above, existing evidence indeed suggests that at least the highest portions of Tamu Massif were initially shallow. Although emplacement rates are not known for most of Shatsky Rise, the radiometric age of the Site 1213 basalts combined with the nearby seafloor magnetic lineations suggests that Tamu Massif was constructed at a very high average rate between 1.2 and $4.6 \mathrm{~km}^{3} / \mathrm{y}$. The upper value is more than a quarter of the 16.8 $\mathrm{km}^{3} / \mathrm{y}$ of new ocean crust (e.g., Larson, 1991) estimated to be formed worldwide today at ocean ridges. Moreover, the estimated $1.8 \times 10^{6} \mathrm{~km}^{3}$ volume of the initial Tamu Massif eruption implies a source volume equivalent to a sphere $224-408 \mathrm{~km}$ in diameter, assuming a mean melt fraction between 5\% and 30\% (cf. Coffin and Eldholm, 1994), a volume consistent with supply by an actively upwelling plume head.

The geometry of Shatsky Rise also appears to support the plume head hypothesis. Apparently, the emplacement rate of igneous rock waned with time, as shown by the northeastward decrease in size coupled with the ages inferred from magnetic lineations; this decrease is consistent with a transition from plume head to plume tail (Sager et al., 1999). A plume-type hypothesis is likewise an attractive explanation for the odd behavior of the Pacific-Farallon-Izanagi triple junction during the $\sim 20$ m.y. that the plateau was forming. The arrival of a plume head, a major source of heat and tensional stress on the lithosphere, is a potential reason for the initial $800 \mathrm{~km}$ jump of the triple junction. Heat and flux of upwelling mantle from a plume might have "pinned" the triple junction near the plume head (and later, tail), explaining the repeated triple junction jumps and the observation that the triple junction did not migrate away from the rise as it should have given the velocities of surrounding plates (Sager et al., 1988). In short, a plume head is a plausible explanation for many Shatsky Rise characteristics.

However, some important observations are not explained easily by the plume head model. The MORBtype isotopic signature of the existing Shatsky basalts already has been noted. Another nagging point is the ridge reorganization that occurred near the time that Shatsky Rise formed. Just after Anomaly M21 time, synchronous with the beginning of Shatsky Rise eruptions, the Pacific-Izanagi Ridge rotated $\sim 30^{\circ}$ (Sager et al., 1988). It is generally accepted that plate motion is driven primarily by subduction (e.g., Lithgow-Bertelloni and Richards, 1998), so it is unclear how a plume head could cause plate velocity to change by acting on the trailing boundary at the ridge. Although a plume may tend to "capture" nearby ridges because it is a major source of heat and actively upwelling mantle (e.g., Kleinrock and Phipps Morgan, 1988), the ridge reorientation occurred $>800 \mathrm{~km}$ from the alleged plume center. If plume activity and plate motions are independent or only loosely coupled, as is widely believed (e.g., Eldholm and Coffin, 2000), the temporal proximity of these two events would have to be a coincidence. 
Another apparent coincidence is the proximity of plume head and triple junction. Although a ridge or triple junction may jump or reorganize to stay near a plume (e.g., Kleinrock and Phipps Morgan, 1988), this assumes that the ridges are already near the plume. How likely is a plume head to rise within 800 $\mathrm{km}$ of a triple junction? Assuming plumes form randomly, the probability of one striking within $800 \mathrm{~km}$ of a triple junction is only $\sim 0.4 \%$. Having a plume head randomly "find" a triple junction would seem to be a low-probability event.

Curiously, western Pacific bathymetry and magnetic lineations seem to imply that other similar plumeridge coincidences occurred. Some other plateaus formed along or near the paths of the Pacific-Farallon-Izanagi triple junction as well as the Pacific-Farallon-Phoenix triple junction, located on the east end of the Pacific plate. Moreover, many of these plateaus are located near proposed ridge reorganizations. After Shatsky Rise, Hess Rise may have formed near the track of the Pacific-Farallon-Izanagi triple junction as it jumped eastward. Similarly, the Magellan Plateau, the oldest part of the Mid-Pacific Mountains, and probably the Manihiki Plateau were all formed near the track of the Pacific-Farallon-Phoenix triple junction (Sager, 2005). Explaining all of these plateaus by plume heads independent of ridge dynamics requires many recurrences of a low-probability event. To remain plausible, the plume head hypothesis must assume that plumes and triple junctions are somehow attracted to each other.

How could ridge tectonics lead to plateau formation? Triple junctions could be the key. Ridges that meet at a triple junction are a focal point for strong upwelling (e.g., Georgen and Lin, 2002), but present-day triple junctions are clearly not sites of plateau formation. The discrepancy between the excess volcanism associated with Late Jurassic and Early Cretaceous Pacific triple junctions and the paucity of such activity during the Late Cretaceous through Cenozoic may be explained by the "fertile" mantle hypothesis (a.k.a., the "perisphere" hypothesis; e.g., Anderson et al., 1992; Anderson, 1995; Smith and Lewis, 1999; Smith, 2003; Foulger, 2007). This hypothesis states that extensive regions of the shallow asthenosphere have a lower melting point (because of higher volatile content, a more mafic composition, and/or higher potential temperature) than the asthenosphere beneath the present-day ridge system. Although the fertile mantle hypothesis is rejected as a general explanation by some, the Late Jurassic-Early Cretaceous Pacific may be a very special case. During this period, much of the Pacific plate (which was then far smaller than at present) may have been located over an anomalously hot region of asthenosphere that now lies beneath the South Pacific Super- swell and which has long been an area of oceanic island and seamount production (e.g., McNutt and Fischer, 1987; Staudigel et al., 1991). Today, this area is far from a spreading center and is characterized by several short-lived, poorly understood hotspots that may represent shallow-sourced plumes or entirely nonplume processes (e.g., Janney and Castillo, 1999; Lassiter et al., 2003; Courtillot et al., 2003; Koppers et al., 2003). Triple junction formation in such an area may have promoted excess melting of anomalously fusible mantle and thus plateau formation. The MORB-type isotopic ratios of the few existing Shatsky samples, all of which are from the last stages of volcanism at their sites, are explicable in this context because isotopically normal MORB-source mantle is predicted to underlie the shallow asthenosphere and to well up and gradually replace it as it melts out and advects away from the melting region (e.g., Anderson, 1995).

Finally, could the rise have been formed by meteorite impact, as Rogers (1982) suggested? This hypothesis readily accounts for the MORB-type isotopic ratios of the Shatsky Rise basalts, as removal of the lithosphere by the impacting object would cause massive melting of the underlying mantle, which normally should be MORB-type mantle. However, this hypothesis requires the coincidence of a large impact (itself a rare event) within $800 \mathrm{~km}$ of a preexisting triple junction, and it fails to explain the $30^{\circ}$ PacificIzanagi Ridge reorientation at Anomaly M21 time and the lack of any evidence for the predicted massive destruction and disruption of seafloor over a very large area surrounding the impact site (Mahoney et al., 2005).

In summary, Shatsky Rise clearly formed in association with plate-velocity changes and ridge and triple junction reorganizations during a period when several plateaus appear likely to have formed near ridges in general and triple junctions in particular. Although the plume head hypothesis can explain many features of Shatsky Rise, it requires significant ad hoc coincidences or modifications. Alternatively, the rise may be explained by anomalous volcanism induced by changes in plate boundaries and lithospheric stress over a region of anomalously fusible mantle. Such a hypothesis requires no coincidence of triple junction location and site of plume impingement and can explain the MORB-type signature of late-stage basalts from Shatsky Rise. However, it also relies on unusual circumstances. Indeed, no matter what the hypothesis, unusual circumstances of some sort appear to be required. At present, data for and against each hypothesis are incomplete and largely circumstantial, and new data are required to move debate forward. This was a primary reason for drilling Shatsky Rise. 


\section{Site survey data and strati- graphic interpretation}

\section{Data acquisition}

The primary data used for selection of sites are lowfold seismic reflection profiles collected during Cruise TN037 of the R/V Thomas G. Thompson in 1994. This data set was also used for Leg 198 and is described in some detail in the Leg 198 Initial Reports (Klaus and Sager, 2002), including plots of most ship tracks and seismic lines. Cruise TN037 also collected swath bathymetry, gravity, and magnetic data. Bathymetry and magnetic anomaly analyses are described in Sager et al. (1999) and Nakanishi et al. (1999), respectively.

Seismic data were collected with a six-channel Teledyne streamer with $25 \mathrm{~m}$ active sections. On any given seismic line, one of two alternate seismic sources was used: (1) a single generator-injector air gun $\left(45 / 105 \mathrm{in}^{3}\right)$ or (2) a four-air gun array $(80,108$, 150 , and $\left.200 \mathrm{in}^{3}\right)$. The generator-injector air gun was mainly used for seismic lines shot between the main bathymetric edifices. It was towed at $\sim 7 \mathrm{nmi} / \mathrm{h}$ and achieved two-fold coverage. The air gun array was used primarily on the mountain tops to penetrate the thicker sediment cover in those locations. The array was typically towed at $\sim 5 \mathrm{nmi} / \mathrm{h}$ and it provided three-fold coverage. Data were digitized at a 1 ms rate and recorded in Society of Exploration Geophysicists (file format " $Y$ ") format. Final shot spacing was $25-37 \mathrm{~m}$. The data were processed through to migration using Sioseis and ProMax software (Klaus and Sager, 2002). Included in the processing train were band-pass filtering (30-150 Hz to $0.25 \mathrm{~s}$ twoway traveltime [TWT] below seafloor, $20-150 \mathrm{~Hz}$ from $0.25-1.0 \mathrm{~s}$ TWT, and $6-70 \mathrm{~Hz}$ below $1.0 \mathrm{~s}$ TWT), deconvolution, normal moveout correction, stacking, and finite difference migration.

\section{Seismic stratigraphy}

Interpretation of the seismic layering is relatively straightforward because of the drilling previously done on Shatsky Rise. A review of the stratigraphy cored during Leg 198 as well as previous cruises is contained in the Leg 198 Initial Reports (Shipboard Scientific Party, 2002a). In general the summits of the high edifices of Shatsky Rise contain thick sections (up to $\sim 1.2 \mathrm{~km}$ thickness) of pelagic sediments. Over the flanks, this sedimentary section is usually much thinner or absent.

The sediment pile is mainly Cretaceous chalk and limestone covered by Cenozoic ooze. Sliter and Brown (1993) divided the section into five units and this was found to be consistent with Leg 198 drilling results (Shipboard Scientific Party, 2002a). Units I and II consist of foraminifer nannofossil ooze with minor clay. Unit I is Neogene in age (often Miocene to Holocene), whereas Unit II is of Paleogene age. Both have similar seismic character, with parallelcontinuous layers, and are often separated by a seismic horizon of modest strength. Units III-V consist of Cretaceous chalk and occasional limestone layers with minor clay and abundant layers and nodules of chert and porcellanite. Indeed, the soft chalk layers interspersed with hard chert and porcellanite have frustrated efforts to recover cores from the top of Shatsky Rise since the beginning of scientific ocean drilling. The three Cretaceous units are often divided by two prominent seismic horizons, dubbed R1 and R2 by Sliter and Brown (1993). In addition, the Leg 198 scientific party used R0 for the horizon nearest the top of the Cretaceous section. The uppermost and lowermost Cretaceous layers show depositional character that is most uniform; however, the middle unit is more sculpted and often shows evidence of erosion and onlap with instances of slumping. The uppermost Cretaceous layer (Unit III) is Turonian to Maastrichtian in age and lies between R1 and R0. The mid-Cretaceous layer (Unit IV) is Aptian to Cenomanian in age and is bounded by R2 and R1. At the bottom of the pile is Unit V, which is Berriasian to Barremian in age and resides between igneous basement and R2 on seismic profiles.

The Cruise TN037 seismic data occasionally show some character in the portion of the record interpreted as igneous basement. Usually, seismic basement is a strong, irregular reflector below which few coherent reflections are seen. In some places on the Ori Massif, dipping reflectors in were noted in acoustic basement. These are likely to be dipping lava flows. On the southwest flank of Tamu Massif, igneous basement was a surprise. All along the seismic line over that flank of Tamu Massif, seismic basement has an odd, layered appearance for about $0.1 \mathrm{~s}$ TWT below the interpreted top of the igneous section. Drilling at Site 1213 during Leg 198 cored 46 m into acoustic basement with this signature, recovering three flow units interpreted as sills (Shipboard Scientific Party, 2002b). At most sites on Shatsky Rise, acoustic basement is strong, has no consistent internal reflectors, and is interpreted as the top of the lava pile.

\section{Scientific objectives}

\section{Testing plume and plate models}

The primary objective of drilling on Shatsky Rise was to sample relatively fresh igneous basement rocks at 
multiple sites on the plateau. Such samples would allow several important problems to be addressed.

\section{Determine the basement age to constrain the time evolution of the plateau.}

Along with the preexisting radiometric dates from Site 1213, geochronologic data will show whether Tamu Massif erupted in a short period, as is currently postulated. A short time span suggests a plume head-like eruption, whereas a longer time span may indicate lower rates of effusion inconsistent with a plume head. The age distribution will place constraints on the types of mechanisms that can explain the initial Shatsky Rise eruptions. In addition, dates from the other Shatsky Rise edifices, Ori and Shirshov massifs, will show whether these edifices were constructed at or near the time of ocean crustal formation and whether the northern part of Shatsky Rise shows an age progression.

\section{Determine chemical and isotopic compositions of igneous rocks cored from Shatsky Rise.}

Although the signature of a lower mantle source is still debated, it is widely expected that mantle plumes erupt igneous rocks with ocean island basalt (OIB) chemical composition and isotopic characteristics postulated to represent the lower mantle or portions of it, such as high ratios of ${ }^{3} \mathrm{He} /{ }^{4} \mathrm{He}$ (e.g., Courtillot et al., 2003). Patterns of geochemical variation across Shatsky Rise will also help establish the plateau formation mechanism. For example, variability could be consistent with evolution or zoning of the mantle source or, alternatively, geochemical characteristics could be homogeneous, as is the case for sampled portions of the OJP.

\section{Determine the source temperatures and degrees of partial melting that produced Shatsky Rise lavas.}

Estimation of source temperatures and the degree of partial melting could be critical to distinguish between an upper or lower mantle source or to test models of abnormal mantle fertility for Shatsky Rise lavas. In general, high degrees of partial melting would be expected for a plume head eruption that is associated with high mantle temperature, especially in locations where the lithosphere is thin (e.g., near a ridge-ridge-ridge triple junction). For example, partial melting of as much as $30 \%$ is interpreted for OJP basalts from phase petrology and the pattern of incompatible element abundances in igneous rock samples (Fitton et al., 2004). On the other hand, regions of abnormally high mantle fertility tapped by the triple junction could result in similarly large melt fractions and high melt extraction rates (e.g., Foulger and Anderson, 2005). Evidence for source temperatures above the ambient mantle temperature, however, may be an important indicator for the existence of thermal (deep-sourced) mantle plumes. Recently, Putirka (2008) proposed an improved method of olivine thermometry to estimate mantle source temperature. Herzberg et al. (2007) also proposed a method to estimate the mantle temperature by using major element composition and phase equilibria. Such approaches may be particularly powerful if combined with results from other studies, such as combined He and Os isotope studies (e.g., Brandon et al., 2007).

\section{Large igneous province geology}

\section{Determine the physical volcanology of} Shatsky Rise eruptions.

Shatsky Rise is a monster volcanic construct. Although they share many characteristics with the thousands of seamounts scattered across the Pacific plate, the Shatsky Rise volcanic edifices exhibit some important differences. One of the more notable is the slope of the rise volcano flanks, which is much lower $\left(\sim 1^{\circ}\right)$ than those of typical seamounts $\left(\sim 5^{\circ}\right)$ (Sager et al., 1999). Another is the apparent mantling of Tamu Massif's southwest flank by sills or sheet flows, as interpreted from Site 1213 data and the seismic character of acoustic basement. Both observations may be indicative of high effusion-rate eruptions. Thus the volcanic stratigraphy may provide important clues about the eruptions of Shatsky Rise igneous rocks. This stratigraphy will be developed from description of igneous rock cores and comparison with logging data.

\section{Determine the magnetic polarity of Tamu Massif and paleolatitudes of Shatsky Rise.}

From a study of the magnetic anomaly of Tamu Massif, Sager and Han (1993) concluded that the edifice is largely of reversed magnetic polarity and was therefore erupted in a short period of time during a period of reversed magnetic polarity. Although inconclusive owing to the small number of independent samples of the magnetic field and the low paleolatitude, the paleomagnetism of igneous samples from Site 1213 is consistent with reversed polarity (Tominaga et al., 2005). Paleomagnetic studies of Tamu Massif sites will establish whether other sites are also of reversed polarity, which would support the hypothesis that this massif formed in a short period of time. In addition, the Jurassic and Early Cretaceous paleolatitude of the Pacific plate is uncertain, so paleomagnetic samples from Shatsky Rise 
have the potential to help establish the paleolatitude of the rise and the Pacific plate.

\section{Determine paleodepths of Shatsky Rise.}

Evidence of subaerial or shallow water paleodepths for the summits of Shatsky Rise massifs will be useful for constraining models of plateau formation. Plume head models predict significant uplift associated with introduction of a large starting-plume head beneath oceanic lithosphere (e.g., Olson and Nam, 1986). Indeed, there is evidence that the Kerguelen Plateau formed landmasses that later subsided below sea level as they moved away from the plume head source (Wallace, 2002). In contrast, OJP basalts were emplaced well below sea level (Fitton et al., 2004). Seismic profiles of Shatsky Rise also imply that the summits of Tamu Massif and Shirshov Massif were above sea level at eruption and subsided to their present depths, but the prediction has yet to be confirmed by sampling. Samples collected from the rise summits during Expedition 324 will establish whether they were originally shallow or subaerial or were emplaced in a deepwater environment. Paleodepths will be established from a number of different indicators, such as microfossils, the types and structures of sediments, conditions of alteration, and measurement of volatile abundances in basaltic glass (e.g., Roberge et al., 2005).

\section{Determine magma evolution and magma chamber processes at Shatsky Rise.}

Geochemical studies of oceanic plateaus suggest that many compositional variations in lavas are controlled by magma evolution processes (fractional crystallization, magma mixing, assimilation, and reaction with cumulates) in large-scale magma chambers. Understanding magma evolution processes in large magma chambers will also help to understand the formation of the cumulate part of the lower oceanic crust. For example, a primary picritic magma must have lost $20 \%-80 \%$ minerals by fractionation in shallow magma chambers to produce OJP basalts (Fitton et al., 2004). Current geochemical data from Shatsky Rise, although sparse, also suggest basement rocks experienced significant fractionation before their eruption (Mahoney et al., 2005). However, the magma chamber scale and evolution mechanism of oceanic plateaus are not clear compared to well-studied MORB. Systematic basement sampling during this expedition could provide information about the magma evolution process from chemical variations of whole rocks. Examination of chemical zoning profiles of phenocryst phases (olivine, plagioclase, and clinopyroxene), recording physiochemical properties (temperature, pressure, and magma compositions) during their growth, can further contribute to reconstruction of the history of magma evolution.

\section{Coring and drilling strategy}

The goal of Expedition 324 was to core as much igneous rock as possible in the time available. Science objectives dictated that coring be distributed over a large area of Shatsky Rise, sampling all three major edifices (Tamu, Ori, and Shirshov massifs) to study geochemical, geologic, and age trends. Furthermore, because Tamu Massif is postulated as a possible plume head eruption, it was considered important to sample several sites across that edifice to examine trends within. The original proposal contained six drill sites as targets. Because of time limitations imposed by the long transit assigned to Expedition 324, this plan was cut to five sites, with three located on Tamu Massif and one each on Ori and Shirshov massifs. Proposed Site SRSH-8 (not drilled) was planned on the southwest flank of Tamu Massif, Site U1347 at the eastern flank of the summit of that edifice, and Site U1348 was planned to sample the lower north flank. The other two sites, U1349 and U1346, were planned at the summits of Ori and Shirshov massifs, respectively.

Of these five sites, four were moved from the originally proposed locations to places where sediment cover was thinner for more rapid penetration of the sedimentary cover. In addition, the drilling plan, which only included rotary core barrel (RCB) drilling, was modified to drill through the uppermost sedimentary cover without coring until $\sim 50 \mathrm{~m}$ above the presumed igneous basement. Although the primary purpose of this move was to speed up drilling through the sediment cover, it was deemed acceptable because the sediments have been cored on many drilling cruises and recovery is usually very low because of cherts interfingered with soft chalk in the Cretaceous part of the sediment cap.

Because of time limitations, coring deeper than would be possible with a single bit was proposed only in one location, Site U1347, on the summit of Tamu Massif. At three of the other sites, the strategy was to core only to $\sim 100 \mathrm{~m}$. For Site U1349, only a single bit was envisioned, but we would drill to bit destruction or $\sim 200 \mathrm{~m}$, whichever came first. Site U1347 was the only multiple-bit hole planned. At this site, two bits would be used, with a free-fall funnel (FFF) for reentry, allowing penetration of $\sim 200$ $300 \mathrm{~m}$ into igneous basement.

Although three of the holes were to be short, downhole logging was planned at all sites. In each hole, two logging strings would be run, the triple combination (triple combo) and Formation MicroScanner 
(FMS). The triple combo would provide density, resistivity, and radiogenic isotope logs as well as caliper measurements that would assess the diameter and condition of the hole. Following the triple combo, the FMS log would be run to provide a resistivitybased image of the borehole wall. Often this log is run in tandem with the sonic log to acquire acoustic velocity data from the formation; however, because of the short length of planned Expedition 324 holes, the sonic log was not to be regularly paired with the FMS. At the planned deep-penetration site, U1347, an additional $\log$, the Ultrasonic Borehole Imager (UBI), an acoustic imaging device, was planned to provide an additional image of the borehole wall.

The final transit for Expedition 324 was to the south and this dictated that the drilling proceed from the northernmost site (U1346) to the southernmost site (proposed Site SRSH-8) so that transit time would be minimized. This was not the ideal arrangement because Tamu Massif sites were given highest priority, but the lost time incurred by sailing back over Shastsky Rise on the final transit was unacceptable. This merely dictated that the science party keep close track of progress during the expedition so that operations did not get far behind the plan.

Although much of Expedition 324 went as planned, actual operations differed slightly from the plan because of weather and science-related changes (see "Operations" section in the appropriate site chapter). After visiting Site U1346 as planned, passing typhoon Choi-Wan forced the ship to sail southward, away from Ori Massif. As a result, Site U1347 was the second site cored. Sites U1348 and U1349 were subsequently drilled in reverse order because the ship approached them from the south, rather than the north as planned. Finally, proposed Site SRSH-8 was not cored at all. As the expedition waned, the science party decided that cores from this site would likely give samples of sheet flows similar to those at nearby Site 1213 ( $\sim 50 \mathrm{~km}$ away). Instead, the science party decided to drill Site U1350, a proposed alternate site on the lower east flank of Ori Massif, as the last site during Expedition 324.

\section{Results}

\section{Site U1346}

Site U1346 is situated at the north edge of the Shirshov Massif summit where acoustic basement is nearly flat, implying a subaerially eroded summit platform (Sager et al., 1999) (Figs. F6, F7). A single hole was drilled (Hole U1346A), penetrating $191.8 \mathrm{~m}$ below the seafloor, with $139.2 \mathrm{~m}$ of sedimentary cover and $52.6 \mathrm{~m}$ of igneous rock (Table T1).
Because the primary goal of drilling Hole U1346A was to recover the igneous basement, sediment coring began only $\sim 70 \mathrm{~m}$ above the suspected basement/sediment interface. Despite difficult drilling conditions, $\sim 4 \mathrm{~m}$ of sediments were recovered in the first six cores prior to entering into basaltic basement. The recovered sedimentary material represents various lithologies and depositional environments, with an average recovery of $10.2 \%$ between 100.5 and $141.7 \mathrm{~m}$ core depth below seafloor (mbsf). The uppermost sedimentary interval, stratigraphic Unit I (Cores 324-U1346A-1W through 3R) yielded only small, isolated pieces of dark chert fragments (Table T2; Fig. F8). Recovery in Cores 4R through 6R improved because of a reduction in the amount of chert in the formation. This short sequence of lithified sediments included an intriguing sequence of intermingled basalt and limestone in Section 324U1346A-4R-1, interpreted as a debris flow (stratigraphic Unit II). In this unit, soft-sediment deformation occurred around the larger volcanic clasts, indicating that the clasts impacted the sediment, either rolling downslope from the eruption source or as a mass flow deposit generated through posteruptive erosion of the volcanic edifice. Section 4R-2 contained a series of laminated volcaniclastic sequences, grading from very coarse sand to clay, which are interpreted as turbiditic in origin (Unit III). The remaining sediments (stratigraphic Unit IV), from the base of Section 4R-2 to the top of 6R-1, are composed of clay-bearing limestones and calcareous mudstones containing abundant shell fragments and other biogenic components, along with glauconite and altered volcaniclastics. Taken together, these components are suggestive of a relatively shallow marine depositional environment in close proximity to a source of volcanic material.

Calcareous nannofossils in the recovered sediments are rare to abundant and moderately to poorly preserved. The age of four samples from Cores 324$\mathrm{U} 1346 \mathrm{~A}-4 \mathrm{R}$ and $5 \mathrm{R}$ is assignable to the Berriasian to Hauterivian. Within the foraminifer assemblage obtained from Section 324-U1346A-4R-CC, the planktonic group is completely absent. Benthic foraminifers are well-preserved, diverse, and representative of the neritic-upper bathyal assemblage (estimated paleodepth $\leq 500 \mathrm{~m}$ ). Various other biogenic sedimentary components were observed in the samples examined for foraminifer analyses; these were dominantly radiolarians with lesser amounts of ostracodes, inoceramid prisms, echinoid plates, sponge spicules, bryozoans, and calcareous fragments.

Basement coring at Site U1346 on Shirshov Massif documented a $\sim 53 \mathrm{~m}$ thick stack of highly vesicular basaltic pillow lavas or lava "inflation units" (strati- 
graphic Unit V) beneath the succession of pelagic nannofossil-bearing chalks and cherts, volcanogenic silts and sands, and volcaniclastic debris (Table T2; Fig. F9). Within the lava stack, individual pillow or inflation units were readily identified by the presence of chilled glassy margins, upper and lower chill zones (Fig. F10), characteristic pillow vesicle patterns, and crystal grain-size variations. In total, 40 individual "lava cooling units" were recognized in the cores from Unit V, but the entire unit was interpreted to represent a single eruptive event.

The pillow basalts are generally vesicular in nature and have zones that are moderately vesicular (30\%$50 \%$ vesicles). Although they appear macroscopically aphyric, a closer inspection reveals that microphenocrysts of olivine and pyroxene were originally present but are now totally replaced by calcite. All samples contain large proportions of less altered, very fine grained plagioclase laths set in a variolitic matrix.

Extensive low-temperature water-rock alteration has left a marked impression on all igneous rocks recovered at this site, resulting in near complete replacement of pyroxene, olivine, and glassy pillow rinds and complete replacement of glassy mesostasis. In contrast, plagioclase shows only slight to moderate alteration. Based on rock color and mineralogy, three types of alteration were determined in Hole U1346A: (1) a green alteration, recovered only in volcaniclastic debris interspersed with sediment at the top of the hole (Unit II; interval 324-U1346A-4R-1, 0-39 $\mathrm{cm})$; (2) a dark gray alteration; and (3) a brown alteration. In the basement pillow lavas, the dark gray alteration is most abundant and is interspersed with the brown alteration throughout the hole. The most abundant secondary minerals observed in the basaltic rocks are clay minerals, and the nature of clay minerals changes with alteration type, from predominantly green clays, including nontronite, in the green alteration, to green and brown clays, including saponite, in the gray alteration, to mainly brown clays in the brown alteration. Calcite is also abundant in all alteration types, replacing pyroxene and olivine, rarely the groundmass, and filling vesicles and veins. Sulfide minerals are present only in stratigraphic Unit II and the upper portions of basement pillow lavas in Sections 324-U1346A-7R-1 and 8R-1. These mineral assemblages suggest that the basaltic rocks from Hole U1346A have extensively interacted with seawater-derived and $\mathrm{CO}_{2}$-rich fluids at low temperature and more locally with S-rich hydrothermal fluids.

Despite the moderate to complete alteration, shipboard analysis of major and several trace elements by inductively coupled plasma-atomic emission spec- troscopy (ICP-AES) in lava samples recovered from stratigraphic Unit $\mathrm{V}$ reveals that the rocks are tholeiitic basalt (Fig. F11). The concentrations of many elements, including $\mathrm{K}, \mathrm{Si}, \mathrm{Ca}, \mathrm{P}, \mathrm{Sr}, \mathrm{Ba}$, and $\mathrm{Ni}$, were modified significantly by the alteration. However, several elements, including $\mathrm{Ti}, \mathrm{Zr}, \mathrm{Y}, \mathrm{Cr}, \mathrm{V}$, and Sc, appear to have been affected relatively little. Relationships among these elements indicate a strong similarity with the older basalts recovered from Site 1213 , which lies $\sim 870 \mathrm{~km}$ southwest of Site U1346.

Both syn- and postmagmatic structures can be recognized within the Hole U1346A igneous complex. The main synmagmatic structural features are amygdules, pillow structures, irregular vein networks or curved veins, and breccias. Postmagmatic structures include conjugate veins and joints. Dip angles of the veins in the hole from top to bottom become gradually steeper; however, joint dips are generally low. The structures observed throughout Unit V are consistent with the interpretation that the rocks are a pile of stacked pillows whose sizes differ from $\sim 20$ to $200 \mathrm{~cm}$.

Gamma ray attenuation (GRA) measurements of the basement sections reveal that there is low variability in bulk density despite changes in the style and degree of alteration. Magnetic susceptibility appeared to be a more sensitive tracer of alteration, and several regions were identified where magnetic susceptibility covaried with changes in alteration style. Thermal conductivity measurements averaged $1.52 \mathrm{~W} /(\mathrm{m} \cdot \mathrm{K})$, with no significant relationship with depth.

$P$-wave velocity measurements of 24 discrete samples showed no appreciable anisotropy or depth relationship and averaged $4.5 \mathrm{~km} / \mathrm{s}$ throughout the core with a maximum of $\sim 5.6 \mathrm{~km} / \mathrm{s}$ and a minimum of $\sim 3.5 \mathrm{~km} / \mathrm{s}$. Moisture and density measurements of bulk, dry, and grain density of the discrete samples confirmed indications from the GRA density (measured on whole cores) that there was little systematic change in the density of the basaltic sequence with depth. Porosity was high and ranged from $8 \%$ to $33 \%$, with the highest values closer to the top of the hole.

In total, 20 discrete samples obtained from Hole U1346A were measured to investigate paleomagnetic remanence of the upper part of the Shirshov Massif basement. Most of samples show a stable component between $300^{\circ}$ and $475^{\circ} \mathrm{C}$ and have low unblocking temperatures $\left(400^{\circ}-450^{\circ} \mathrm{C}\right)$, which is characteristic of titanomagnetite (or titanomaghemite). Alternating-field demagnetizations show that the magnetization is stable after 10-15 mT demagnetization. The samples from Hole U1346A are characterized by shallow negative inclinations with an arithmetic mean of $-20.3^{\circ} \pm 5.3^{\circ}(1 \sigma)$. 
Downhole logging data obtained from Hole U1346A included natural and spectral gamma ray, density, photoelectric factor (PEF), and electrical resistivity measurements from three depths of investigation. Interpretations of gamma ray and electrical resistivity downhole logs were used to identify 14 logging units in Hole U1346A, with three in the section covered by the bottom-hole assembly (BHA), four in the sedimentary sequences in the open hole interval, and seven in the basaltic basement. The sedimentary sequence shows several prominent gamma ray anomalies associated with $U$ enrichment. The most prominent anomaly is found at the sediment/basement interface and may be indicative of focused hydrothermal fluid flow. Shallower anomalies recorded through the BHA may represent oceanic anoxic events previously interpreted in this area. Electrical resistivity measurements in the basaltic basement show four distinctive massive zones characterized by higher resistivity values, which may represent individual thick lava flows. Relatively high $\mathrm{K}$ content in the basement section also indicates a high degree of hydrothermal alteration.

\section{Site U1347}

Site U1347 is situated on the upper flank, east of the summit of Tamu Massif (Fig. F12). The site location was chosen at a spot where sediments are thin and the "layered basement" signature seen elsewhere on the southern Tamu Massif is also thin (Fig. F13). Drilling in a single hole (U1347A) penetrated 317.5 $\mathrm{m}$ below the seafloor, including a $157.6 \mathrm{~m}$ sedimentary section and a $159.9 \mathrm{~m}$ igneous section (Table T1).

Coring recovered $17.7 \mathrm{~m}$ of sediment (stratigraphic Units I-III) in Cores 324-U1347A-1W through 11R over a stratigraphic interval of $\sim 158 \mathrm{~m}$ before entering basaltic basement (Table T2). The recovered sediments are dominated by radiolarian-rich volcaniclastic siltstones, with varying proportions of glauconite (Fig. F8). There are also minor intervals of chert and claystone. Bioturbation is often pervasive in the silty facies, with rip-up clasts and erosional contacts as common features, suggestive of turbulent and transient depositional events. Sediments are also present as relatively thin interbeds between the massive basaltic flows and pillow basalt units within the igneous complex. These sediments are similar in character and composition (e.g., predominantly radiolarian-bearing siltstones) to the sediments above basement, although some show features consistent with thermal alteration as a result of subsequent basalt emplacement.

Calcareous nannofossils and foraminifers from the sediments of Site U1347 are generally moderate to poor in preservation and low in abundance and diversity. Intercalated sediments in the underlying basement section are almost barren of both microfossil taxa. Fortunately, the age of four samples from Cores 324-U1347A-2R and 10R is assignable to the Berriasian to Valanginian based on calcareous nannofossils. The foraminifer assemblage is marked by the absence of planktonic forms. Benthic foraminifers, although the total number of specimens is limited, are characterized by a neritic assemblage in the lower part of the sediment section (Cores 6R through $8 \mathrm{R}$ ) and a bathyal assemblage upsection (Cores $1 \mathrm{R}$ through $2 \mathrm{R})$. Therefore, an overall deepening trend from $<200 \mathrm{~m}$ to $200-2500 \mathrm{~m}$ is inferred. Samples processed for foraminifer analyses are to a large extent dominated by volcanogenic lithic fragments and minerals; the major biogenic component is radiolarians with peaks in size, abundance, and diversity in Cores $6 \mathrm{R}$ through $8 \mathrm{R}$.

After penetrating the sediment section, a $159.9 \mathrm{~m}$ thick volcanic basement succession (Units IV-XVI) (Table T2; Fig. F9) was encountered, consisting of "packages" of massive basalt flows and pillow inflation units intercalated by five sedimentary successions up to $\sim 5 \mathrm{~m}$ thick. Based on the dominant type of eruptive unit, the volcanic basement can be described in three main packages or groups. From top to bottom, these are: Group 1, an upper "layered" series of four massive lava flows ( 8-19 m thick) (Fig. F14) intercalated with two $\sim 5 \mathrm{~m}$ thick sediment packages and totaling $\sim 60 \mathrm{~m}$ in thickness (Units IV, V, VII, and IX); Group 2, a $~ 75$ m lava stack consisting for the most part of pillow basalts (each $\sim 0.2-1.0$ $\mathrm{m}$ thick) (Fig. F15) and medium-size inflation units (1-2 $\mathrm{m}$ thick), interspersed by relatively thin sedimentary intercalations and three larger $(\sim 3-6 \mathrm{~m}$ thick) basalt flows (Units X, XII, and XIV); and Group 3, a lower set of two particularly massive basaltic lava flows consisting of a very thick upper ( 23 $\mathrm{m})$ homogeneous lava flow that overlies a unit of similar character at the bottom of the hole (Units XV and XVI). In many instances, the high recovery (average $=64.2 \%$ ) for Hole U1347A igneous basement yielded well-preserved lower- and upper-contact zones with chilled margins, baked sediment contacts, and folded pahoehoe-type upper crusts. The frequent recovery of thick (often fresh) glassy rinds within the pillow-unit stack indicates that alteration was essentially buffered in these rocks.

In Group 1 the three uppermost massive flows are aphyric (stratigraphic Units IV, V, and VII) and petrographically different from the sparsely to moderately pyroxene-plagioclase phyric basalt in the fourth flow (Unit IX) and the lavas lower in the succession. Examination of unit thicknesses within Group 2 re- 
veals a pattern of repetition, beginning with massive inflation units, passing upward into predominantly medium-size units, and then into a sequence of closely packed pillow lavas, before the cycle is repeated. These repetitions may represent repeated eruptive pulses during which the lava effusion rate diminished. Group 3 includes the lowest two lava flows recovered (Units XV and XVI); they have welldeveloped chilled margin zones at their tops (glassy to microcrystalline in the topmost $\sim 2 \mathrm{~m}$ ) and thinner ones $(\sim 0.5 \mathrm{~m})$ at their bases. Thick glassy rinds were not recovered in these flows and vesiculation is confined to the upper 2-3 $\mathrm{m}$, below which the flows become very homogeneous and massive and largely nonvesicular. It may be deduced from their large thickness that these flows are likely to be laterally extensive "tabular flow" units, possibly similar in dimension to those described in flood basalt provinces.

The majority of the volcanic units are plagioclase-pyroxene phyric basalts. Toward the cores of the lava flows and pillows, crystallinity increases to $50 \%$ and in some cases to $95 \%$. Most notable are the appearance of plagioclase phenocrysts in the fourth massive flow in the upper volcanic group (stratigraphic Unit IX), the rarity or absence of clinopyroxene phenocrysts in the lower pillow stack (Units XII and XIV), and their absence in the lowermost massive flows (Units XV and XVI). In all cases the basalts were saturated in both clinopyroxene and plagioclase; these minerals always seem to occur together as clusters or glomerocrysts intergrown in the matrix between the larger microcrysts and phenocrysts. The rocks appear, therefore, to have been in a condition of low-pressure plagioclase-clinopyroxene cotectic crystallization during all stages of cooling and differentiation. Olivine phenocrysts occur rarely as earlycoprecipitating liquidus minerals and now are completely replaced by clays and calcite. Remnants of fresh olivine with melt inclusions or spinel were discovered only in a few thin sections. Titanomagnetite is highly variable throughout the lava succession, as also reflected in highly variable magnetic susceptibility. For instance, glass in the chilled margins has no discernible titanomagnetite and consequently low magnetic susceptibilities. However, spherulitic overgrowths on plagioclases and larger (sometimes elongate skeletal) titanomagnetite grains increase significantly toward the cores of the (thicker) lava flows, and are correlatable to increased magnetic susceptibility readings.

Overall, basalts of Hole U1347A appear to have more differentiated compositions compared with basalts from basement at several other sites cored on Shatsky Rise (Sites 1213, U1346, and U1349). This is evident from the predominance of plagioclase and clinopyroxene intergrowths at all stages of crystallization, the scarcity of olivine, and the almost complete absence of $\mathrm{Cr}$ spinel. This phenocryst assemblage and character of intergrowths compare well to those of rather evolved low-temperature gabbros formed in "shallow" crustal magma chambers beneath fast- and superfast-spreading ridges.

Alteration within the volcanic section varies from slight to moderate (estimated to range from $5 \%$ to $50 \%$ ). Generally, both the primary mineralogy (with the exception of extensive olivine replacement) and finer spherulitic textures in the interstices between phenocrysts and microcrysts are well preserved, especially close to pillow margins. Sometimes fresh glass is still present in the groundmass. In contrast, away from the pillow margins, the glassy mesostasis in the groundmass is almost completely replaced. Plagioclase and clinopyroxene are generally well preserved throughout the hole, both in the groundmass and as phenocrysts. Clay minerals, together with calcite, are the most abundant secondary minerals in Hole U1347A, replacing primary phases and glassy mesostasis and filling vesicles and veins. Pyrite is widespread throughout the hole, being present in the groundmass, vesicles, and veins. Three main types of veins were observed: (1) calcite veins, which predominate; (2) green clay veins, and (3) composite veins of calcite + green clays \pm pyrite. There is an average of $\sim 3$ veins $/ \mathrm{m}$ in the basement lavas and average vein thickness is $\sim 1 \mathrm{~mm}$. No significant variation in alteration mineralogy was observed in Hole U1347A. Alteration of the basaltic rocks is interpreted to result from interaction with seawater-derived fluids at relatively low temperature $\left(<100^{\circ} \mathrm{C}\right)$.

Two kinds of structures were distinguished within the igneous complex: pillow structures and sheet flow structures. The typical sheet flow structure is normally characterized by three parts: (1) an upper lava crust, (2) a middle lava core, and (3) a basal zone. Dip angles of both veins and joints in the hole become gradually steeper downhole. The entire structure of the Hole U1347A igneous complex is consistent with stacked layers of pillows and massive basalt sheet flows. Taking the horizontal sedimentary bedding into account, structural observations indicate that the site has undergone no tilting or horizontal-axis block rotation.

Onboard measurements of major and several trace elements by ICP-AES reveal that the Site U1347 lavas are tholeiitic basalts (Fig. F11). The chemical effects of posteruptive alteration are smaller than for samples of other Expedition 324 sites, especially the highly altered rocks cored at Sites U1346 and U1349. In general, both the major and trace element compo- 
sitions are consistent with the Site U1347 basalts being variably more evolved relatives of the basalts at Site 1213 on the southern flank of Tamu Massif. Compared to normal ocean-ridge basalts, the Site U1347 lavas exhibit modest relative enrichment in the more highly incompatible elements, qualitatively similar to that seen in the Site 1213 basalts. This result suggests a mantle source slightly richer in the more incompatible elements than normal oceanridge source mantle and/or that the Site U1347 magmas formed by slightly smaller amounts of partial melting and possibly in the presence of residual garnet.

Magnetic susceptibility in the igneous rocks is typically $\sim 2000 \times 10^{-5}$ SI and GRA density is from 2.4 to $2.6 \mathrm{~g} / \mathrm{cm}^{3}$. The massive flow (stratigraphic Unit XV) below 290 mbsf notably reaches magnetic susceptibilities as high as $3800 \times 10^{-5} \mathrm{SI}$ and also has the highest measured densities. Total counts of natural radiation measured in igneous rocks were between 2 and $4 \mathrm{cps}$ throughout the hole, which is an order of magnitude less than observed at Site U1346. Fiftyeight thermal conductivity measurements of igneous rocks were performed, yielding an average of $1.59 \pm$ $0.200 \mathrm{~W} /(\mathrm{m} \cdot \mathrm{K})(2 \sigma)$. One sedimentary measurement of $1.007 \pm 0.017 \mathrm{~W} /(\mathrm{m} \cdot \mathrm{K})(2 \sigma)$ was also obtained. In general, the massive igneous units have slightly higher thermal conductivity than the pillow units. This is seen particularly well in the lowermost massive flow unit below $\sim 290 \mathrm{mbsf}$, which has a thermal conductivity of $1.733 \pm 0.092 \mathrm{~W} /(\mathrm{m} \cdot \mathrm{K})(2 \sigma ; N=11)$.

$P$-wave velocity measured on discrete samples showed no appreciable anisotropy but appeared to vary with stratigraphic units. The Unit XV massive flow and upper pillow basalts (Unit X) have high compressional wave velocities (up to $7.04 \mathrm{~km} / \mathrm{s}$ ). The high velocities are coincident with low porosity $(<5 \%)$ and high bulk densities $\left(>2.75 \mathrm{~g} / \mathrm{cm}^{3}\right)$ measured by discrete sampling.

A total of 61 discrete samples were measured to investigate paleomagnetic remanence of the upper part of the Site U1347 basement. Only about half of the samples demagnetized by thermal demagnetization show a stable component, whereas most samples demagnetized by alternating-field demagnetization show a fairly stable component between 15 and 80 $\mathrm{mT}$. Most samples have low unblocking temperatures of $\sim 300^{\circ}-400^{\circ} \mathrm{C}$, which is characteristic of titanomagnetite (or titanomaghemite). We suggest four magnetic zones downhole: (1) Section 324-U1347A$12 \mathrm{R}-1$, with shallow negative inclination $\left(-6^{\circ} \pm 7^{\circ}\right.$; $1 \sigma$ ); (2) Sections 12R-2 through 16R-5 (lower part of the massive basalt Flows 1-3; stratigraphic Units IV, $\mathrm{V}$, and VII), with an average inclination of $28^{\circ} \pm 13^{\circ}$; (3) Sections 17R-2 through 26R-1 (basalt Flow 4 and pillow lava section; stratigraphic Units IX-XIV), with an average inclination of $20^{\circ} \pm 14^{\circ}$; and (4) Sections 26R-2 through 29R-4 (basalt Flows 5 and 6; stratigraphic Units XV and XVI), with an average inclination of $54^{\circ} \pm 27^{\circ}$. Whereas results in the upper three zones appear reasonably reliable, detailed rock magnetic analyses are necessary to interpret the erratic magnetic behavior of the lowermost zone.

Downhole logging data obtained from Hole U1347A included natural and spectral gamma ray, density, neutron porosity, PEF, and electrical resistivity measurements from three depths of investigation. Interpretations of gamma ray and electrical resistivity downhole logs were used to identify 15 logging units, with 3 in the sediment sequences and 12 in the basaltic basement. These units correlate well with those defined by core material logging. Electrical resistivity measurements in the basaltic basement show distinctive high-resistivity zones that likely represent massive flows and pillow flow units interspersed with low-resistivity zones that mark sediment interbeds. Natural gamma ray measurements show five intervals of higher readings that indicate interbedded sediments within the basaltic basement. These sedimentary intervals also display higher $\mathrm{K}$ values. FMS images show zones of distinctive pillow lavas, zones with high fracture density, and intervals that seem to represent massive lava flows.

\section{Site U1348}

Site U1348 is located on the north flank of Tamu Massif (Fig. F12). The target for drilling was the upper part of a basement high where sediments are thin (Fig. F16). A single hole (U1348A) was drilled at the site, with $324.1 \mathrm{~m}$ of penetration below the seafloor (Table T1).

A thick sequence $(\sim 120 \mathrm{~m}$ stratigraphically) of volcaniclastic sediments, topped with shallow water calcareous sandstones, greenish clays, nannofossil ooze, and chert, was recovered from Hole U1348A (Fig. F8). The uppermost cores (stratigraphic Unit I) contained red chert interbedded with a remarkably well preserved, section of Cenozoic-Late Cretaceous nannofossil ooze over a meter long (Core 2R). Yellow brecciated cherts were also recovered stratigraphically below the red cherts and above highly silicified, altered sandstones. Below this, a sequence of shallow-water bioclastic sandstones (Unit II) with volcanic clasts was found (Cores 10R through 13R). This sequence includes an interval of bright green zeolitic clays. Although basaltic basement was not reached at this site, Cores $14 \mathrm{R}$ through $26 \mathrm{R}$ recovered a unique sequence of highly altered marine volcaniclastic rocks (Units III-VI). Based on the marine fossil content and bedding 
structures, these have been interpreted to represent a mixture of in situ and re-deposited material that was erupted in a submarine environment.

Micropaleontological investigations revealed that the sediments from the upper cores of stratigraphic Unit I (Cores 324-U1348A-1W through 10R) are pelagic in origin and, although recovery was dominated by chert-rich lithologies, are generally suited for calcareous microfossil studies. A few centimeters of gray ooze in the wash barrel's core catcher (Core $1 \mathrm{~W})$ and in the uppermost centimeters of the undisrupted nannofossil ooze are rich in Cenozoic (Miocene) calcareous and siliceous microfossils (Core 2R). Microfossils of mid- to Late Cretaceous age occur in Cores 324-U1348A-2R through 10R. Calcareous nannofossils are subject to progressive reduction in abundance, diversity, and preservation state with increasing burial depth. Planktonic foraminifers contained in this interval are generally well preserved and abundant. A series of primary/secondary zonal marker species that correlate well to the standard biochronology are recorded by planktonic foraminifers, ranging from the early Aptian to early Campanian (120-80 Ma), and they are used for construction of the age model for this site. Therefore, the underlying units are considered to be $>120 \mathrm{Ma}$ in age. Benthic foraminifers show remarkable changes in abundance and diversity throughout the hole, and the subsidence history of Tamu Massif from upper to lower bathyal depth can be discerned.

The $\sim 120 \mathrm{~m}$ thick volcaniclastic succession of stratigraphic Units III-VI (Cores 324-U1348A-14R and below) consists predominantly of hyaloclastite (Figs. F9, F17). The lithology ranges from matrix-supported clay- or sand-size hyaloclastite to dominantly heavily compacted granule- or pebble-size clast-supported hyaloclastite in the bottom of the hole. Petrography reveals that the volcanic glass shards and larger vitric clasts are thoroughly altered, with minor admixtures of bioclastic materials, fossil debris, and well-preserved calcitic fossils at some horizons. In contrast to other Expedition 324 drill sites, no massive or pillow lava flow successions were encountered.

The hyaloclastite succession proved difficult to interpret because of pervasive, and often complete, alteration of the volcanogenic constituents, which masks both original composition and structure. A minority of sparsely vesicular hyalobasalt fragments occur, especially in the upper horizons (stratigraphic Units III-IV), yet high proportions of altered volcanic glass shards and clasts occur throughout, increasing to almost completely form the hyaloclastitic rocks in the clast-supported packages of Unit VI. Under the microscope these fragments appear to have originally been sparsely vesicular vitric clasts, broken down into abundant glass shards, which were subsequently exposed to intense alteration and compaction. The predominance of altered glass shards throughout Units III-VI is indicative of substantial submarine volcanism. Sedimentary reworking of these primary hyaloclastite constituents is evident in some units.

With only one exception, the original hyaloclastite composition has been entirely transformed to secondary palagonite, zeolite, and calcite. This replacement commences with the alteration of volcanic glass shards to palagonite, which is mainly composed of montmorillonite and nontronite. This process starts along the rims and continues with the development of alteration spheroides within the glass shards. Further progression of this process resulted in complete replacement of the edges of these shards, followed by replacement of the glass cores by a combination of zeolite and calcite. Some rare lithic fragments show similar texture and degree of alteration to basaltic rocks recovered at the top of Hole U1347A. However, even these clasts show almost complete replacement of primary phases and transformation to brown clays. Clay minerals, together with calcite and zeolites, are the predominant secondary minerals in Hole U1348A. Vitric and lithic clasts are cemented by calcite and/or zeolites, with variations in their occurrences and proportions downhole. Fibrous and tabular zeolites (i.e., phillipsite) commonly form a corona of alteration around the palagonite particle rims and cement, with or without calcite, the volcanic clasts.

In one unique horizon, cuspate, sparsely vesicular fragments of volcanic glass, consisting of numerous unaltered contiguous glass shards, were recognized in one continuous $\sim 26 \mathrm{~cm}$ interval (324-U1348A23R-1, $110-126 \mathrm{~cm}$, and 23R-2, 1-8 cm). In the rest of the core hyaloclastite fragments are identifiable only from their pseudomorphed glass shard outlines. However, toward the bottom of the hole (in stratigraphic Unit VI) even these pseudomorphed forms have been mostly obliterated through alteration and by a large amount of compaction of this hyaloclastite material by the overburden. The preservation of the few glass fragments in Sections 324-U1348A-23R1 and 23R-2 seems to result from an early "armoring" of these vitric clasts by impermeable calcite. In these samples, the glass clasts contain no phenocrysts and preserve only a sparsely microcrystic primary mineralogy of fresh olivine and intergrown plagioclase and pyroxene. These clasts are only sparsely vesicular and typically show the incipient and/or partial transformation to palagonite, seen so pervasively throughout this succession. 
Two kinds of structures, primary structure and postdepositional structure, are observed in the volcaniclastic stratigraphic Units III-VI. Bedding as primary structure is often displayed by layered fine and granular hyaloclastite sequences that are interbedded in coarser hyaloclastitic breccia. Sedimentary stratification, including graded bedding and cross bedding, is observed particularly in the fine-grained hyaloclastites. Most strata, however, are parallel and show only shallow dips $\left(<30^{\circ}\right)$. Postdepositional structures cut through the bedding, including microfaults and veins. Veins are typically 0.1 to $1.5 \mathrm{~cm}$ thick. Both microfaults and veins show steep dip angles $>50^{\circ}$.

Two samples from clay-rich layers in sedimentary stratigraphic Unit II have relatively high concentrations of $\mathrm{SiO}_{2}, \mathrm{~K}_{2} \mathrm{O}$, and $\mathrm{Zr}$ and very low concentrations of $\mathrm{CaO}, \mathrm{P}_{2} \mathrm{O}_{5}$, and $\mathrm{TiO}_{2}$, as determined by ICPAES. The clay-rich layers may contain a large proportion of material derived through wind or water transport from continental crust and/or one or more magmatic arcs. However, some of the $\mathrm{SiO}_{2}$ in these two layers may have come from circulating solutions that originated in overlying or underlying beds.

Clasts and bulk samples of volcaniclastic material from stratigraphic Units III, V, and VI show the chemical effects of complete alteration, greater even than that at Site U1346, on average. However, the ZrTi relationship among the samples is similar to that seen for the tholeiitic basalts of Site U1347 (Fig. F11) and suggests that the Site U1348 volcaniclastic rocks were derived from magmas broadly similar in composition to those that fed the Site U1347 lavas.

Physical properties (magnetic susceptibility and bulk density) of clastic stratigraphic Units III-VI correlate well with varying concentrations of volcaniclastic material (versus more calcite rich intervals). Average magnetic susceptibility generally decreases downhole from $\sim 40-45 \times 10^{-5}$ SI near the top of Core 324U1348A-15R to less than $20 \times 10^{-5}$ SI near the bottom of the hole (Core 26R). A few excursions to 100 $\times 10^{-5}$ SI occur in intervals 324-U1348A-17R-1, 0-10 $\mathrm{cm}$, and 58-60 cm; 19R-1, 106-108 cm; 20R-1, 18$118 \mathrm{~cm}$; and 20R-4, 73-92 cm. GRA bulk density and bulk density of discrete samples are between 1.8 and $2.4 \mathrm{~g} / \mathrm{cm}^{3}$. Natural gamma radiation averages between 10 and $30 \mathrm{cps}$, with highest spectral peaks corresponding to ${ }^{40} \mathrm{~K}$. Porosity of discrete samples is high $(27 \%-55 \%)$. $P$-wave velocity of discrete samples, from 2.0 to $3.3 \mathrm{~km} / \mathrm{s}$, varies inversely with porosity and directly with bulk density.

Because no basaltic basement was recovered and hyaloclastites typically have weak magnetism, paleomagnetic measurements were only made on eight discrete samples of volcaniclastic sediment. These samples likely carry a depositional remanent magnetization instead of a thermoremanent magnetization. Therefore, any directional result will be more complicated to interpret. The $2 \mathrm{G}$ cryomagnetometer was used for these measurements because the natural remanent magetization of these samples was too weak to be measured on the Molspin Minispin magnetometer (a few tens of $\mathrm{mA} / \mathrm{m}$ ). Only alternatingfield (AF) demagnetizations were carried out, using the DTech degausser. The low magnetic susceptibilities (between $4 \times 10^{-4} \mathrm{SI}$ and $8 \times 10^{-4} \mathrm{SI}$ ) indicate that magnetic minerals are not abundant in these samples. Compared to the basalt samples from other Expedition 324 holes, the samples have a higher median destructive field (between 10 and $25 \mathrm{mT}$ ), which suggests that the magnetization carriers are single-domain grains. In five cases, once the low-coercivity overprint is removed, it is possible to isolate a stable component pointing toward the origin. Inclinations are mostly shallow and positive, between $4^{\circ}$ and $23^{\circ}$, although one sample gives a negative inclination $\left(-9^{\circ}\right)$.

Downhole logging data obtained from Hole U1348A included natural and spectral gamma ray, density, $\mathrm{PEF}$, and electrical resistivity measurements from three depths. Interpretations of gamma ray and electrical resistivity downhole logs were used to identify 15 logging units with one in the section covered by the BHA, five in the sedimentary sequences in the open hole interval, and nine in the volcaniclastic section. Electrical resistivity measurements show distinctive higher resistivity zones that likely represent less altered intervals interspersed with low-resistivity zones that mark sediment interbeds and more altered sequences. Natural gamma ray measurements show several intervals of higher readings that indicate interbedded sediments and greater amounts alteration. These intervals also display higher $\mathrm{K}, \mathrm{U}$, and Th values. FMS images show zones with distinct horizontal layering, dipping beds, and vesicular or brecciated intervals. Preliminary structural analyses of dipping beds show features striking northeastsouthwest and dipping mostly $20^{\circ}-30^{\circ}$ to the southeast.

\section{Site U1349}

Site U1349 is located at the summit of Ori Massif (Fig. F18) on a flat-topped basement ridge (Fig. F19) that may have been planed flat by wave erosion. Hole U1349A penetrated $250.4 \mathrm{~m}$ beneath the seafloor, through $165.1 \mathrm{~m}$ of sediment and $85.3 \mathrm{~m}$ of igneous basement (Table T1).

In total, $10.1 \mathrm{~m}$ of sediment was obtained from Cores 324-U1347A-1W through 7R over a stratigraphic interval of $49 \mathrm{~m}$ (average recovery $=\sim 20 \%$ ) 
(Fig. F8). Cores $1 \mathrm{~W}$ through $4 \mathrm{R}$ recovered predominately red chert with occasional ooze and porcellanite intervals (stratigraphic Unit I). Below this, a friable sand-silt-claystone sequence was found that also contains granules of highly weathered volcanic material (Units II and III). This interval, however, is so disturbed by drilling that further interpretation of the rock is difficult. Most of Cores 5R and 6R contain greenish gray volcaniclastic sandstones and lapillistones, likely deposited by turbiditic flows. A thin, yellowish red clay-rich horizon in Section 324U1349A-6R-CC is interpreted as a paleosol within the deepest purely sedimentary section recovered. In the underlying basement, several other thin sedimentary beds are found between basaltic lava flows. The most significant of these is a piece of oolitic limestone in Section 9R-1 at 173.7 mbsf, which logging data suggest is $\sim 6 \mathrm{~m}$ thick.

Calcareous microfossils occur in chalk that encrusts reddish cherts and in pinkish nannofossil ooze in Cores 324-U1349A-1W through 4R, whereas the underlying siliciclastic and volcaniclastic sediments of Cores $4 \mathrm{R}$ through $7 \mathrm{R}$ are barren. Nannofossils are rare to common in abundance but poorly preserved throughout. Planktonic foraminifers are represented in exceptionally high abundance and diversity with good preservation in the nannofossil ooze recovered in Core 2R. Zonal marker and other age-diagnostic species strongly indicate a narrowly constrained age at the middle-late Albian transition. Although a foraminifer material is scarce, other examined levels above and below are also marked by the occurrence of some age-diagnostic species, allowing the entire age range of Cores $1 \mathrm{~W}$ through $4 \mathrm{R}$ to be estimated as Albian-Cenomanian. Core $2 \mathrm{R}$ also yielded a diverse benthic foraminifer assemblage; the estimated bathymetric range is middle bathyal.

Volcanic basement was encountered in Core 324U1349-7R at 165.1 mbsf (Table T2; Fig. F9). The cored basaltic succession of stratigraphic Unit IV is $\sim 55 \mathrm{~m}$ thick (Sections 324-U1349A-7R-2 through 13R-4) and consists of 25 lava units characterized by high (40\%-75\%) vesicularity, the presence of magma mixing features (Fig. F20), and, in all but the interiors of the thickest inflation units, a pervasive reddish brown Fe oxyhydroxide hematite alteration. This succession also contains 10 recovered weathered flow tops readily identified by a reddening over $\sim 5-$ $10 \mathrm{~cm}$ intervals, tentatively interpreted as subaerial alteration occurring between the emplacement of successive eruptive units. In the top $\sim 10 \mathrm{~m}$ of this lava succession, the flow inflation units are relatively thin $(\sim 0.3-1.1 \mathrm{~m})$. Whereas many have highly vesicular reddened flow tops, a number of examples preserve interflow carbonate sediment. The most signif- icant of these is an oolitic limestone that is preserved at the top of a highly vesicular flow. Other instances of this interflow carbonate sedimentation are preserved only as carbonate infilling of vesicle voids within flow tops. In addition to the subaerial exposure inferred elsewhere in Unit IV, these filled-vesicle flow tops record contrasting periods of shallow marine inundation of the lava field. The lowermost part of Unit IV contains a series of much thicker (1-6 m) massive flows. Preliminary comparisons to degassing models for basalt in Hawaii, and assuming 0.05-0.5 $\mathrm{wt} \% \mathrm{H}_{2} \mathrm{O}$ concentrations in the source, imply pressures below 15-20 bar in order to produce the high (40-70 vol\%) vesicularity in the lavas of Unit IV, corresponding to $<100 \mathrm{~m}$ water depth.

Beneath the lava succession of stratigraphic Unit IV is a transition to flow breccia at $221.7 \mathrm{mbsf}$ (Table T2; Fig. F9). This section consists of $\sim 29 \mathrm{~m}$ of an alternating assemblage of massive lava pods and fragmental basalt. The lava pods are vesicular, though to a lesser degree than the flow tops in Unit IV, on average $\sim 1 \mathrm{~m}$ thick and range in thickness between 0.5 and $2 \mathrm{~m}$. The assemblage is interpreted as a series of autobrecciated inflation units (Unit V).

Petrographic examination reveals that the basalts of both stratigraphic Units IV and V are all Cr spinelbearing and olivine-phyric. Based on ICP-AES analyses, these basalts have $>8 \%-15 \% \mathrm{MgO}$ and thus may be termed picritic. Olivine phenocrysts are sparsely to moderately abundant (up to 4\%) but are usually entirely altered to iddingsite, clays, and $\mathrm{Fe}$ oxyhydroxides. The groundmass of some rocks contains abundant "ophimottle" crystal aggregates up to $\sim 5 \mathrm{~mm}$ in size and consisting of well-preserved clinopyroxene ophitically intergrown with plagioclase. Iron oxyhydroxides and secondary hematite are present in the groundmass and responsible for the brownish red color of the rocks in the lower part of Units IV.

Extensive water-rock interactions under variable temperature conditions resulted in complete replacement of glassy mesostasis and olivine phenocrysts in both stratigraphic Units IV and V. Both plagioclase and clinopyroxene are generally well preserved in Unit IV, whereas below 218 mbsf (bottom of Unit IV and Unit V, from Section 324-U1349A-13R-5 to 16R-7), alteration is more pronounced, with nearly complete replacement of clinopyroxene and almost complete replacement of plagioclase microliths. The overall alteration of the basaltic rocks ranges from high to complete. Three types of alteration were determined in Hole U1349A (from top to the bottom): (1) a red-brown alteration (upper and middle of Unit IV), (2) a transitional alteration (bottom of Unit IV), and (3) a green alteration (Unit V). In addition, suba- 
erially weathered flow tops have been identified within Unit IV. Clay minerals (saponite, nontronite, and montmorillonite) are the predominant secondary minerals in Hole U1349A samples, replacing glassy mesostasis and primary phases (olivine, plagioclase, and pyroxene) and filling vesicles and veins. Calcite and hematite are also abundant secondary minerals, especially in Unit IV. Secondary mineral assemblages change with depth from clay minerals + hematite + calcite in the red-brown alteration to clay minerals + chlorite + zeolite \pm hematite in the transition zone to saponite \pm serpentine in the green alteration. This suggests variations in alteration conditions starting with subaerial oxidative tropical weathering within Unit IV. Upon submergence of the lavas, relatively low temperature, oxidizing seawater alteration occurred at the top of the hole (producing the red-brown alteration) and transitioned to more reducing and higher temperature alteration toward the bottom of the hole (resulting in the green alteration).

The severe alteration has affected and modified the bulk-rock chemical compositions of the basement rocks significantly. In addition, chemical evidence is present for accumulation of olivine, and possibly clinopyroxene, crystals in the melt. The combined effects of crystal accumulation and alteration hinder interpretation of magmatic liquid compositions. However, shipboard measurements indicate that the Site U1349 samples are the least differentiated of any Shatsky Rise basement rocks analyzed. Both the lava section of Unit IV and the autobreccia of Unit V appear to be low- $-\mathrm{TiO}_{2}$, low-Zr tholeiitic basalts with similarities to primitive ocean-ridge and OJP basalts (Fig. F11).

Aspects of the mineralogy, especially the compositions of clinopyroxenes and intergrown plagioclase in the ophimottled rock, and of Cr spinel throughout, might further help in constraining the primary composition of the Hole U1349A lavas (i.e., prior to alteration). Perhaps the most pressing question concerning the pervasive alteration of stratigraphic Units IV and V has to do with the high alteration temperature inferred for some portions of these units. Oxy-exsolution is observed in all titanomagnetite crystals and may indicate that alteration approached temperatures up to $600^{\circ} \mathrm{C}$. However, no secondary minerals indicative of such high temperatures (epidote, actinolite, etc.) were observed.

Structural data are consistent with the interpretation that Hole U1349A penetrated several stacked sheet flow units, some of which are intercalated with limestone. Evidence for apparently subaerial features (including pahoehoe structures) and submarine structures (including pillow lava and brecciated pillow lava) is clear. The typical sheet flows at this site have three parts: (1) an upper lava crust with horizontal zones of hollow vesicles, (2) a middle lava core with quite regular, well-developed veins in a fine-grained groundmass and low vesicularity, and (3) a basal zone with fewer vesicles and few veins. In this hole, no joints are observed, but veins are well developed. Vein dips become steeper downhole in the upper part of the igneous succession, become shallower again, and then steepen downhole again.

Physical property measurements can be used to distinguish four of the five units (II-V) of Hole U1349A. No discrete samples were taken from the chert fragments of Unit I, nor was the material continuous enough for whole-round track measurements. Volcaniclastic sandstones and claystones of Unit II and volcaniclastic sandstones and lapillistones of Subunit IIIa yielded magnetic susceptibilities $<1000 \times$ $10^{-5} \mathrm{SI}$, GRA densities $<2.0 \mathrm{~g} / \mathrm{cm}^{3}$ and natural gamma radiation (NGR) counts between 10 and 40 cps. Three discrete measurements of Unit II and Subunit IIIa revealed high porosities (20\%-40\%) accompanied by $P$-wave velocities $<4.0 \mathrm{~km} / \mathrm{s}$. Thermal conductivity measurements yielded low values between 1.01 and $1.57 \mathrm{~W} /(\mathrm{m} \cdot \mathrm{K})$, typical of sedimentary material.

Beneath the sandstones of Unit II and Subunit IIIa, a volcaniclastic conglomerate (Subunit IIIb) can be distinguished clearly by excursions to extremely elevated magnetic susceptibility. A distinct spike reaching almost $4000 \times 10^{-5} \mathrm{SI}$, the highest value measured during Expedition 324, is derived from an individual volcanic clast in Section 324-U1349-7R-1 containing abundant groundmass magnetite. The upper oxidized portion of the vesicular basalts of Unit IV, lying below the conglomerate, has low magnetic susceptibility $\left(<1000 \times 10^{-5} \mathrm{SI}\right)$ and low total NGR counts ( $<20$ cps) similar to sedimentary Unit II and Subunit IIIb, but is distinguishable by higher GRA density $\left(>2.0 \mathrm{~g} / \mathrm{cm}^{3}\right)$. Discrete sample measurements confirm higher bulk density $\left(>2.5 \mathrm{~g} / \mathrm{cm}^{3}\right)$, lower porosity $(<10 \%)$, and higher $P$-wave velocities (4.0-6.0 km/s) compared to the sedimentary units. Core 324-U1349-11R in Unit IV marks the end of the oxidized zone and shows an increase in magnetic susceptibility, averaging $1000 \times 10^{-5} \mathrm{SI}$, with excursions to values $>2000 \times 10^{-5} \mathrm{SI}$. The increase in magnetic susceptibility is not accompanied by any significant difference in GRA density, porosity, or $P$-wave velocity compared to the oxidized material above. Thermal conductivity measurements throughout Unit IV, irrespective of relative oxidation, yielded some of the highest values recorded during Expedition 324 and averaged $1.799 \mathrm{~W} /(\mathrm{m} \cdot \mathrm{K}) \pm 0.357(2 \sigma ; N$ $=22$ ). 
The autobrecciated basalt of Unit V is clearly distinguishable from the vesicular basalts above by a decrease in magnetic susceptibility (average $=100 \times 10^{-5}$ SI). Total counts from the NGR show a muted decrease to 5-10 cps, whereas GRA density remains similar to that of the basalts above. Discrete sampling reflects the heterogeneous distribution of clasts within Unit V, showing large variations in porosity, $P$-wave velocity, and, to a lesser extent, bulk density. Thermal conductivity measurements reflect the higher porosities measured in the unit, yielding values lower than the basalts, with an average of $1.364 \mathrm{~W} /(\mathrm{m} \cdot \mathrm{K}) \pm 0.305$ $(2 \sigma ; N=10)$.

A total of 32 basement samples were demagnetized for paleomagnetic studies (18 AF and 14 thermal demagnetizations). As expected, samples from volcaniclastic units show demagnetization results in which a characteristic remanent magnetization is difficult to isolate. These samples likely carry a depositional remanent magnetization, which makes the interpretation more complicated. Samples from olivine-phyric amygdaloidal basalt flows were characterized by a high-coercivity, high unblocking-temperature magnetization carrier. It is still unclear whether this magnetization is carried by titanomagnetite, in which case it is a true thermoremanent magnetization, or by hematite, in which case it is a chemical remanent magnetization. Both minerals have been identified in thin section. In any case, additional rock magnetic measurements and interpretations are necessary in order to interpret these results. The average inclination in Hole U1349A is $-4.3^{\circ} \pm 5.9^{\circ}(1 \sigma)$, suggesting that the lavas in Hole U1349A were formed near the magnetic equator.

Downhole logging data obtained from Hole U1349A included natural and spectral gamma ray, density, and electrical resistivity measurements from three depths of investigation. Interpretations of gamma ray and electrical resistivity downhole logs were used to identify 19 logging units, 1 in the section covered by the BHA, 5 in the sedimentary sequences in the open hole interval, and 13 in the basaltic basement section. Electrical resistivity measurements show distinctive higher resistivity zones that likely represent less altered intervals interspersed with low-resistivity zones that mark more altered sequences. NGR measurements show a large peak just below the sediment/basement interface that may indicate a zone of concentrated hydrothermal alteration. This interval also displays very high $U$ values and a smaller peak in $\mathrm{K}$ values. FMS images show zones with highly fractured intervals, potential veins, and vesicular or brecciated intervals.

\section{Site U1350}

Site U1350 is located on the lower east flank of Ori Massif (Fig. F18) where sediments are thin and the underlying acoustic basement appears to be relatively strong and smooth (Fig. F21). The site was chosen because it has a setting similar to Site U1347, which yielded relatively fresh basalts, and because it would provide a valuable comparison with the summit of Ori Massif (Site U1349). A single hole (U1350A) was drilled at the site, penetrating $143.1 \mathrm{~m}$ of sediment and $172.7 \mathrm{~m}$ of igneous basement to a total depth of $315.8 \mathrm{~m}$ (Table T1).

Because recovery of the soft sediments overlying the igneous basement was poor, only one purely sedimentary unit was defined at Site U1350 (Unit I); this unit spans Cores 324-U1350A-1W through 6R (Fig. F8). Although it is likely Unit I is composed of both chert and soft calcareous ooze or chalk, only chert (predominantly black and less commonly reddish) with minor amounts of occluded porcellanite was recovered. Well-preserved radiolarians, concentrated around relict burrow features, are common in the cherts of Unit I. Igneous basement was reached in Core 6R at 143.1 mbsf (Table T1), but additional sediments were encountered interbedded with the basaltic strata in Units II and IV. These sediments were predominantly fine-grained carbonates with a persistent radiolarian component and volcaniclastics. Varying quantities of assorted bivalve and brachiopod fossils were also present. Sedimentary interbeds were especially abundant in Unit IV (Cores 25R and 26R), where carbonate-rich oozes have been intruded by small pillow basalts prior to lithification (Fig. F22).

Calcareous nannofossils sampled from chert-rich lithologies of Unit I and Subunit IIa (Cores 324U1350A-1W through 9R) are common to high in abundance and moderately to poorly preserved. The assemblage is indicative of Early Cretaceous age. However, these two units are almost barren of both planktonic and benthic foraminifers, with only a few silica-replaced specimens. The intercalated limestones of Unit IV are severely recrystallized and do not yield any calcareous microfossils. A low-diversity, poorly preserved assemblage of radiolarians is present throughout the examined Site U1350 sediments. No contact between the sediment of Unit I and the volcanic basement was recovered.

The upper part of the igneous basement (Unit II) (Fig. F9) contains both massive basalt flows and pillows and larger, pillowlike inflation units, with the percentage of massive flows decreasing with depth. Below this is a $\sim 6 \mathrm{~m}$ thick layer of hyaloclastite and 
brecciated basalt (Unit III), followed by a succession of well-preserved plagioclase-phyric pillow lavas set in a matrix of intercalated micritic limestone (Unit IV), as described above. Unit II may be divided into an upper $\sim 77 \mathrm{~m}$ thick succession (Cores 324U1350A-6R through 16R) predominantly consisting of a series of larger inflation units, yielding recovered thicknesses of 1-2 m, with two larger (3-5 m thick) flows. This succession is sparsely intercalated with thin layers of volcanogenic limestone (Subunit IIa) (Fig. F23). Below is a middle ( $19 \mathrm{~m}$ thick) transitional succession (Sections 324-U1350A-17R-1 through 19R-1) in which larger inflation units of 1-2 $m$ thickness are intercalated with smaller pillow lava units (Subunit IIb). The pillows display chilled margins, glassy contacts, and vesicle distribution patterns similar to those of pillow units observed in Holes U1346A and U1347A. At the base of Unit II is a $\sim 50 \mathrm{~m}$ stack of $0.2-0.9 \mathrm{~m}$ thick pillow lava units (Sections 324-U1350A-19R-1 through 24R-2) with wellpreserved glassy contacts and chilled margins (Subunit IIc) (Fig. F24). Within Subunit IIc, the lowermost $\sim 23 \mathrm{~m}$ consists of a well-preserved stack of units displaying pillow/pillow contacts, relatively thin glass rims, and chilled margins but lacking intercalated sediment layers. In this lowermost part, the pillow units are sparsely plagioclase phyric (up to $2 \%$ ), and magnetic susceptibility abruptly diminishes to lower values characteristic of Units III and IV below.

The pillows of Unit II lie atop $\sim 6 \mathrm{~m}$ of hyaloclastite (Unit III) (Figs. F9, F25) consisting of gravel- to sandsize glassy material, larger hyaloclastite fragments, and/or small pods $(\sim 5-15 \mathrm{~cm})$ of aphyric basalt (Sections 324-U1350A-24R-3 through 24R-4. The aphyric basalt pods appear to be petrographically similar to Unit II above, but on the whole the hyaloclastite is a sufficiently different facies to merit is own division and represents a thin series of autobrecciated inflation units. The lowermost $\sim 1 \mathrm{~m}$ of Unit III in Section 324-U1350A-24R-4 consists of gravel and pebble-size fragments only, preventing identification of the contact between Unit III and the underlying volcanic succession.

The lowermost, 19 $\mathrm{m}$ thick sequence (Unit IV) (Fig. F9) consists of Cores 324-U1350A-25R and 26R with extremely high recovery ( $>90 \%)$. These cores preserve a stack of $\sim 0.1-0.5 \mathrm{~m}$ thick plagioclase-phyric pillow lavas ( $6 \%$ plagioclase), including the sedimentary material that occurs between individual pillow lavas (Fig. F22). Glassy rinds and thick, chilled margins can be examined readily, and pillow/pillow and pillow/sediment contacts are abundant throughout. Thermal alteration effects can be observed at most basalt/sediment contacts, especially in exam- ples where the pillow lava was injected into soft sediment. The encasement of some pillow units within sediment indicates that the substrate onto and into which the pillow lavas were extruded was unconsolidated and/or fluidized by the entry of hot lava.

Thin section examination shows that crystallites in well-preserved glass rims are mainly plagioclase and clinopyroxene; spinel is not present in the basalts of Hole U1350A. Groundmass textures consist of networks of interlocking acicular plagioclase around which both clinopyroxene and titanomagnetite have crystallized to varying proportions, depending on grain size and rate of cooling. Only in the transitional succession of Subunit IIb do some well-developed networks of interlocking clinopyroxene and plagioclase occur as clumps or aggregates at all grain sizes.

The entire basement section (massive lava flows, pillow lavas, and hyaloclastites) has been affected by slight to high amounts of low-temperature waterrock interaction, resulting in complete replacement of glassy mesostasis and olivine phenocrysts and slight to almost complete replacement of groundmass minerals (plagioclase and clinopyroxene). In contrast, plagioclase phenocrysts are generally well preserved throughout the hole, except in Unit IV. Fresh glass is commonly preserved on the margins of flows and pillows in Subunits IIa and IIb, rarely preserved in Subunit IIc, and not preserved in Units III and IV. One type of gray alteration was identified, with significant variation in alteration degree, from slight to moderate in the upper flow succession and hyaloclastites (Units II and III), to moderate to high in the plagioclase-phyric pillow succession (Unit IV). Clay minerals, together with calcite, are the predominant secondary minerals in Hole U1350A, replacing primary phases and glassy mesostasis and filling vesicles and veins. Other alteration minerals observed in the basaltic rocks are pyrite and zeolites, present as filling vesicles and veins, and possible sanidine, replacing plagioclase phenocrysts in Unit IV. Four main vein types were identified in the basaltic rocks of Units II to IV: (1) calcite veins ( \pm pyrite), (2) saponite veins, (3) calcite and saponite veins ( \pm pyrite), and (4) pyrite veins. A total of 461 veins and vein networks were recorded in the recovered $75 \mathrm{~m}$, corresponding to an average of 6.1 veins $/ \mathrm{m}$. Most of the veins in Hole U1350A are calcite veins, consisting of either crystalline blocky calcite or crossfiber calcite. Alteration of Hole U1350A samples is comparable to the alteration mineralogy encountered in Hole U1347A on Tamu Massif.

The chemical effects of the alteration are comparatively modest at Site U1350. The shipboard chemical data reveal that the basement section is composed of 
variably evolved tholeiitic basalts (Fig. F11). Broad similarities with the Site U1347 and Site 1213 basalts are present, but the Site U1350 lavas also differ in important respects: for example, they show systematic downhole variation in several key chemical parameters, exhibit a wider range of $\mathrm{TiO}_{2}, \mathrm{Zr}$, and $\mathrm{Mg}$ numbers, extend to higher $\mathrm{Mg \#}$ values (as high as 68.5), and have higher Sr concentrations. They also show a wider spread of $\mathrm{Zr} / \mathrm{Ti}$ ratios, implying that variations in amount of partial melting and/or source composition were important.

The overall structure of the basement can be divided by the hyaloclastite of Core 324-U1350A-24R (Unit III) into two kinds of extrusive structures: (1) sheet flow lavas with intercalated pillows in the upper part and (2) piled-up pillows in the lower part. Both parts are characterized by synmagmatic structures, including inter- and intrapillow structures. Interpillow structures are structures observed in the rocks surrounding the pillows. In the upper part of the hole, the surrounding rocks are characterized by hyaloclastite breccias or calcite fillings. In the lower part of the hole, interpillow structures are characterized by limestone, which shows only weak bedding. Intrapillow structures are similar in texture throughout the hole, but differ in size from $\sim 5$ to $\sim 30 \mathrm{~cm}$ depending on the size of the pillows. They are characterized by thin glassy margins, radially aligned vesicles, concentric vesicular zones, and spheroidal shapes. In addition, structural features can be divided by syn- and postmagmatic structures. Synmagmatic structural features are represented by amygdaloidal structure, irregular vein networks or curved veins, and breccias. Postmagmatic structures are conjugate veins and joints. Dip angles of both veins and joints vary irregularly with depth. A larger population of veins and/ or joints is found in the lower part of the hole (Unit IV).

The physical property data separate the basement into three distinct units or divisions based on magnetic susceptibility: (1) Cores 324-U1350A-7R through 11R ( 150-190 mbsf), (2) Cores 12R through 21R ( 190-270 mbsf), and (3) Cores 22R through 26R ( 270-316 mbsf), and into three distinct, but different, units based on NGR: (1) Cores 324-U1350A-7R through 10R ( 150-175 mbsf), (2) Cores 11R through $24 \mathrm{R}(\sim 175-295 \mathrm{mbsf})$, and (3) Cores 24R through 26R ( 295-316 mbsf). Interestingly, neither set of divisions corresponds with any of the stratigraphic units, except for the lowermost NGR division. Magnetic susceptibility shows a decreasing downhole trend from $>2000 \times 10^{-5}$ SI in the upper portion of Subunit IIa to $<1000 \times 10^{-5}$ SI in the lowermost Unit IV. A sharp decrease in magnetic susceptibility is found between Cores 324-U1350A-21R and 22R within the pillow basalts of Subunit IIc. This decrease corresponds to the disappearance of sediment interbeds and the onset of a continuous stack of pillows.

Data from the Natural Gamma Ray Logger yields generally low counts ( $<5 \mathrm{cps})$, with two notable exceptions. The exceptions occur in the upper portion of Subunit IIa and in the lower part of Unit IV. Examination of spectra from both of these intervals shows that counts are dominated by products of ${ }^{40} \mathrm{~K}$ decay. This is in agreement with the increased K-rich alteration (clays) seen in the lowermost part of Unit IV. The GRA bulk density is consistently around 2.5 $\mathrm{g} / \mathrm{cm}^{3}$ throughout Units II-IV. Bulk density measurements of discrete samples agree fairly well with the maximum values of the whole-round data, having uniform values with an average of $2.61 \pm 0.17 \mathrm{~g} / \mathrm{cm}^{3}$ $(2 \sigma)$. Porosity measurements on discrete samples are from $3.43 \%$ to $28.45 \%$ and display a good negative correlation with $P$-wave velocity, as expected. $P$-wave velocity shows no appreciable anisotropy and averages $4.793 \pm 1.249 \mathrm{~km} / \mathrm{s}$, which is typical for basaltic material and of a similar range to measured velocities in igneous rocks in all sites. Overall, discrete physical property measurements do not change significantly with different stratigraphic units.

A total of 42 samples were analyzed for paleomagnetism (18 AF and 24 thermal demagnetizations). AF demagnetizations were characteristic of low-coercivity magnetic minerals, except for the samples from Sections 324-U1350A-25R-2 to 26R-1. All the AF-demagnetized samples have a stable direction pointing toward the origin, but the inclinations derived from principal component analysis show a large spread, between $-12^{\circ}$ and $27^{\circ}$. Thermal demagnetizations indicate a large distribution of Ti content in the samples. Principal component analysis carried out on the thermal demagnetization specimens defined stable magnetization components but also led to a scatter of inclination values. Overall, inclinations are shallow, both positive and negative, but with large variations even within the same stratigraphic unit.

Because the logging tools were unable to leave the drill pipe and enter the open hole, only gamma ray measurements could be recorded from inside the BHA. The gamma ray data in the shallow sediments show an anomaly from the seafloor to $\sim 25 \mathrm{~m}$ wireline log matched depth below seafloor. The contributions to this anomaly are mainly an increase in Th and a smaller contribution from $U$. 


\section{Synthesis}

\section{Sediments}

Despite the fact that the recovery of igneous basement was the main objective of Expedition 324, $>100 \mathrm{~m}$ of sedimentary material was recovered from the five sites drilled on Shatsky Rise. The variety of different sediments, ranging in age from Early Cretaceous to middle Cenozoic, represents several different depositional environments. As anticipated, the dominant stratigraphic facies in the uppermost cores at all sites is chert interbedded with chalk and calcareous oozes. At every site, these sediments make up Unit I (Fig. F8). The combination of chert and soft chalks undoubtedly contributed to the consistently poor recovery of this unit, which was often limited to one or two chert fragments per core. The sediments comprising Unit I are indicative of pelagic carbonate and silica-rich deposition at each of the massifs, initiated once that portion of the volcanic platform had subsided out of the photic zone. Age constraints within this facies are somewhat difficult to determine, but generally range from Berriasian through middle Cenozoic, suggesting that open-marine sedimentation was the dominant mode of deposition for the majority of Shatsky Rise's posteruptive history. The persistently high radiolarian component present in many of the stratigraphic units is testimony to high productivity, probably associated with the position of Shatsky Rise near the paleoequator during much of the Early to mid-Cretaceous.

Other (nonpelagic) sedimentary material was also recovered from many of the sites, including bioclastic limestones, radiolarian-rich siliciclastics, and thick volcaniclastic sequences (Fig. F8). This unexpected diversity of basal material may help to illuminate the complex history of sedimentation and subsidence at Shatsky Rise, after the main volcanic-edifice building phase had ceased but before fully pelagic sedimentation was initiated. Interestingly, sediments were found interbedded with igneous material comprising the basaltic basement at several of the sites. These sediments, largely undated thus far, may yet yield invaluable information about the relative duration of eruptive events and the environment into which these igneous units were emplaced.

The discovery of shallow-water sediments at many sites, and even subaerial basal sediments at one site, suggests that Shatsky Rise may have been a semiemergent archipelego rather than a purely submarine edifice during the Early to mid-Cretaceous. Lithologic and biologic indicators for shallow marine depositional environments include carbonate-rich sediments, shallow-water fossil assemblages, and the occurrence of small possible wood fragments, glau- conite, and sedimentary structures suggestive of shallow water deposition.

Tamu Massif, at the southern end of Shatsky Rise, is thought to represent the oldest part of Shatsky Rise. At the southernmost site drilled during Expedition 324, Hole U1347A on the eastern flank of the massif, Early Cretaceous sediments (Berriasian to late Valanginian) were found overlying basement, confirming age estimates from previous studies. These sediments include a $\sim 60 \mathrm{~m}$ sequence of graded and laminated radiolarian-rich sand-silt-claystones (Fig. F8), which contain diverse trace fossils and occasional body fossils, such as the ammonite fragments found in Core 324-U1347A-8R. The sedimentary material is fine grained, probably of volcanic origin, and contains bedding structures indicative of deposition by turbidity currents. Glauconitic radiolarites and silicified limestones overlie these laminated siltstones and contain preserved radiolarian tests, replaced in many cases by green glauconite minerals. Additionally, the material is cross-bedded in a style indicative of very shallow marine conditions, at or above wave base, suggesting a shallowing-upward sequence prior to subsidence and deposition of the pelagic chertrich facies.

Material recovered from the second Tamu Massif site (U1348), on the northern flank, sharply contrasts with that recovered from Site U1347 and represents sedimentation in a large range of depositional environments. Basaltic basement was not reached at this site despite drilling to $>320 \mathrm{mbsf}$, although a large proportion of the material at this site is volcanic in origin and probably represents redeposited hyaloclastic (volcanic glass) material from submarine eruptions (Fig. F8). The sedimentary structures in this succession are suggestive of hydraulic sorting and include laminations and graded bedding (both reverse and normal), as well as erosional contacts, making deposition by the action of turbidites or debris flows probable. Shallow-water fauna such as well-preserved crinoids and gastropods are present within some of these volcaniclastic units, indicating the environment was relatively shallow and marine. Unfortunately, age constraints for these unique volcaniclastic units prove elusive, although a tentative Early Cretaceous age can be assigned based on radiolarian assemblages and the biostratigraphic ages of overlying sediments. Other highlights from Site U1348 include the recovery in Core 324-U1348A$12 \mathrm{R}$ of green zeolitic and celadonite-rich clays thought to represent altered ash beds, and sandstones predominantly formed of tabular coral fragments in Core 11R. A $25 \mathrm{~cm}$ section of early-middle Aptian foraminifer-bearing calcareous ooze was recovered in Core 10R and may provide an invaluable 
record of Pacific paleoceanography during this crucial mid-Cretaceous transition. Another remarkably well preserved section (1 m long) of nannofossil ooze, thought to span the Late Cretaceous Santonian to Campanian transition, was also recovered in Core 324-U1348A-2R. A small piece of gray ooze at the top of this core and the contents of the wash core (324U1348A-1W) above are middle Cenozoic in age, suggesting either contamination from material much higher in the borehole or a genuine hiatus between the Late Cretaceous and middle Cenozoic at this site.

Ori Massif, north of Tamu Massif, is thought to represent either a later phase of volcanism or a rifted segment of the larger edifice. Two sites were drilled on Ori Massif; the first (Site U1349) is centered on the summit and the second (Site U1350), $70 \mathrm{~km}$ away, is on the eastern flank of the massif. The basaltic basement at Site U1349 was heavily altered and covered by a sequence of volcaniclastic conglomerate, breccia, and sandstones (Fig. F8). A weathered, highly oxidized horizon in Core 324-U1349A-6R is interpreted as a paleosol, providing direct evidence for subaerial exposure. Evidence for very shallow water emplacement of the uppermost lava flows at Site U1349 comes from interbedded oolitic bioclastic limestones in Cores 324-U1349A-7R and 9R. Only sparse sedimentary material, in the form of black chert, was recovered above basement at Site U1350 (Fig. F8), but an interesting sequence of limestones intruded small pillow lavas was recovered in the lowest part of the hole within Cores 324-U1350A-25R and 26R.

Northeast of Ori Massif lies Shirshov Massif, presumed to be the youngest of the volcanic edifices at Shatsky Rise on the basis of magnetic lineation data. Site U1346 was drilled on Shirshov Massif on the northern rim of the summit. The basaltic basement at this site was reached at 139.2 mbsf, underlying a largely pelagic sedimentary sequence. Only the lower portion of these sediments was cored, beginning at 100.5 mbsf. Although sedimentary recovery averaged only $\sim 10 \%$, the diversity and sequential changes within this material provide a record of the subsidence of the volcanic platform. Directly overlying the basement, shallow-water biogenic limestones were recovered (Fig. F8), consisting primarily of a fine-grained carbonate matrix with abundant shell fragments, foraminifers, radiolarians, echinoids, and glauconite. Oxidized fragments of scoriaceous material as well as small (millimeter size) possible wood fragments were identified in these limestones, suggesting that there was a landmass nearby. Upward in the sequence the biogenic component of the limestones decreases, develops laminated bedding structures, and contains larger amounts of siliciclastic ma- terial in the silt and clay size range. A large spike in $U$ content was observed in the NGR data toward the top of the limestone succession, within Core 324U1346A-5R. A fine-grained volcaniclastic turbidite deposit was recovered above the limestones (Fig. F8); it is similar to the finer hyaloclastic material recovered at Site U1348 on Tamu Massif. Present within this meter of laminated mud and fine sandstones are at least three major fining-upward sequences bounded by erosive contacts. The sediments are mostly composed of clays and altered volcanic glass with varying amounts of iron oxyhydroxide minerals, glauconite, and radiolarians. Another limestone package rests above the turbidite; it is interbedded with altered vesicular basalt. The carbonates in this unit are fine grained, occasionally sparry (indicating recrystallization of the calcite), and laminated and contain several dark clay-rich bands. These carbonates are interpreted to represent deeper water sedimentation. The basalt/sediment contacts are convolute, indicating that the basalt was likely emplaced while the sediment was still soft. However, there is no evidence of chilled margins, which suggests the basalt had already cooled and solidified before being mixed with the sedimentary material by slumping or debris flow.

\section{Biostratigraphy}

Shipboard studies of calcareous microfossils (calcareous nannofossils, planktonic foraminifers, and benthic foraminifers) allow new constraints to be placed on the evolutionary history of Shatsky Rise. At Sites U1346 and U1347, Early Cretaceous calcareous nannofossils and benthic foraminifers were retrieved from calcareous and/or siliciclastic sediments immediately above the basaltic basement. The youngest estimated basement ages, based on calcareous nannofossils, are Berriasian-Hauterivian for Site U1346 and Berriasian-Valanginian for Site U1347. These estimates compare well with the ages delineated by magnetic lineations (Fig. F3). Benthic foraminifers comprise a unique monofamily assemblage, which has not been reported from any other Cretaceous Pacific deep-sea sections and gives paleowater depths of $<500 \mathrm{~m}$ for Site U1346 and $<200 \mathrm{~m}$ for Site U1347 (Fig. F26). This finding provides an independent line of evidence for shallow-water or subaerial eruption of Shirshov and Tamu massifs, complementing other sedimentological and physical volcanological observations.

At Site U1348, the pelagic sediment cover of Tamu Massif (northern flank) yields diverse, abundant planktonic foraminifers ranging in age from the mid- to Late Cretaceous (Aptian-Campanian). The nearly linear age-depth relationship shows the ab- 
sence of a major sedimentation gap. The recovery of 120 Ma ooze (early Aptian), probably the oldest known fresh pelagic sediment, is not noteworthy, and guarantees stable isotopic study of individual foraminifer species. Future progress in taxonomic, paleoecological, and paleoceanographic studies of foraminifers is anticipated.

\section{Physical volcanology and igneous petrology}

The volcanology of Shatsky Rise is more complex than initially anticipated, with each hole exhibiting different characteristics and combinations of units (Fig. F9). The typical igneous units are, in order of increasing size: (1) pillow lavas ( 0.2-1.0 m diameter) displaying typical glassy rinds, chilled zones, internal vesicle distributions, and joint patterns; (2) pillowlike inflation units ( 0.8-2.0 $\mathrm{m}$ thick) displaying glassy rinds or contacts, chilled zones, vesicular tops, and degassed interiors with pipe vesicles; (3) small massive flow units ( 2-4 m thick) with vesicular tops, homogeneous, coarser grained interiors with pipe vesicles and segregation features, and narrow basal chilled zones; and finally (4) large massive flow units ( 5-23 m thick) with narrow, glassy upper contacts, vesicular tops grading down into vertically extensive, nonvesicular, degassed interiors with sparse, well-developed pipe vesicles and segregation features, a coarser crystal groundmass, and a narrow basal chilled zone. Overall, the vesicularity of the igneous units was high, and most sites are characterized by a high proportion of smaller sized inflation units. However, although the large massive flow units are less common, they can constitute a significant proportion of the core. Often the basalts are intercalated with or directly overlain by relatively to very shallow marine sediments, indicating that most lavas erupted at shallow water depths and low hydrostatic pressures. In one instance, at Site U1349, several reddened flow tops occur, probably indicative of subaerial eruption, or at least a period of emergence.

The five volcanic basement sites may be summarized as follows:

- Site U1346 on Shirshov Massif consists of $~ 53 \mathrm{~m}$ of highly vesicular pillow lavas and larger pillowlike inflation units of aphyric micro- to cryptocrystalline basalt. These are interpreted as part of a single pillow lava stack. The nature of the sedimentary intercalations within the succession indicates that the environment deepened progressively from nearshore to offshore marine conditions throughout the eruptive period.

- Site U1347 is on the southeastern flank of Tamu Massif ( $200 \mathrm{~km}$ northeast of Hole 1213B). The $\sim 160 \mathrm{~m}$ thick basement succession consists of massive basalt flows and pillow inflation units intercalated with volcaniclastic sedimentary layers. The basalts include (1) an upper series of four massive lava flows ( 8-19 m thick); (2) a $\sim 75 \mathrm{~m}$ lava stack with more massive ( 3-6 $\mathrm{m}$ thick) basaltic flows passing upward to pillowlike inflation units (1-2 $\mathrm{m}$ thick) and pillow basalts $(<1 \mathrm{~m}$ thick), which likely represent successive eruptive pulses during which lava effusion rates diminished; and (3) two massive, internally homogeneous lava flows consisting of a very thick $(\sim 23 \mathrm{~m})$ upper massive (tabular) flow overlying a second (partially penetrated) flow. The frequent recovery of thick, often fresh, glassy rinds within the pillow stack indicates that alteration was essentially buffered in these rocks.

- Site U1348, on a basement high on the north flank of Tamu Massif, is unusual in that it provided $\sim 120 \mathrm{~m}$ of volcaniclastic sediments, including $\sim 90 \mathrm{~m}$ of hyaloclastite. This material initially proved difficult to interpret because of pervasive alteration, which masks both the original texture and structure of this lithology. However, chemical composition, measured from a few large basaltic clasts, is consistent with that of the lavas found at the other sites. The predominance of altered glass shards is indicative of substantial submarine volcanism nearby.

- Site U1349 was drilled near the top of Ori Massif. The upper sedimentary section is the usual chertchalk sequence, which changes downhole to volcaniclastic materials containing fragments of basalt. Beneath the volcaniclastics is a weathered volcanogenic conglomerate that lies unconformably upon red-brown basaltic flows. These thin altered lavas have extremely vesicular flow tops, many of which are deeply reddened, probably as a result of subaerial weathering, and are intercalated with multiple limestone (oolitic) horizons indicative of periodic marine incursions. Increasingly thicker lava inflation units occur toward the bottom of the lava section before passing into an underlying submarine succession of lava flow breccias, hyaloclastite fragments, and more massive, irregularly shaped lava pods. Accordingly, this volcanic sequence appears to have developed in progressively shallower to emergent conditions, followed by submergence after volcanism ceased.

- Site U1350 is $70 \mathrm{~km}$ east of Site U1349 on the eastern flank of Ori Massif, where the seafloor is $\sim 800$ $\mathrm{m}$ deeper. Drilling penetrated $\sim 173 \mathrm{~m}$ into volcanic basement and yielded (1) a series of massive basalt flows passing downhole into (2) a transitional zone, (3) aphyric to sparsely plagioclasephyric pillow lavas, (4) a thin layer of hyaloclas- 
tite, and (5) a succession of well-preserved plagioclase-phyric pillow lavas set in a matrix of originally unconsolidated or fluidized micritic limestone. The inflation units above the hyaloclastite are complex, containing a mixture of massive flow and pillowlike units sparsely interspersed with thin sedimentary horizons. Beneath the hyaloclastite, the high core recovery preserved in great detail an intricate stack of small pillow lavas $\left(\begin{array}{ll}0.1-0.5 \mathrm{~m}) \\ )\end{array}\right.$ baked contacts. Alteration was minimal toward the top of this hole, comparable with that observed in Hole U1347A.

From a petrological point of view, Shatsky Rise presents a basaltic province in which plagioclase-clinopyroxene intergrowths are well developed, from the early crystallization of mottles with ophitic textures (Hole U1349A) to the formation of sparse phenocrysts and glomerocrysts (Holes 1213B, U1347A, and U1350A) to the quench stage and the stage of coarser grained crystallization in the interiors of flows and pillows (all holes). This petrographic attribute is evident even among the rare and tiny quench crystals in the one glassy sample recovered among the hyaloclastites of Hole U1348A. The basalts of Holes U1346A and especially U1349A are more primitive than at other sites, carrying fairly abundant olivine and $\mathrm{Cr}$ spinel, and yet the plagioclase-clinopyroxene intergrowths occur even in the altered glass margins of these rocks. The above observations indicate that, at all stages of crystallization, the temperature interval between the onset of plagioclase crystallization and that of clinopyroxene crystallization was negligible. Experimentally, this is not a usual feature of MORB at low pressure, with the exception of melts containing significant dissolved water. A range of temperatures may have existed, and that will be determined by onshore mineral studies, but in all cases plagioclase and clinopyroxene crystallized cotectically.

Some of the basalt in Hole U1349A can be termed picritic; however, these rocks differ from the only well-documented picrite found on modern spreading ridges. More evolved olivine tholeiite from drill sites on the Mid-Atlantic Ridge still has an obvious gap in crystallization temperature at all cooling rates between plagioclase and later clinopyroxene. As MORB-like as Shatsky Rise basalt may be in its geochemistry, in this one respect it is different.

\section{Alteration}

Basaltic rocks forming the Shatsky Rise have all undergone pervasive fluid-rock interaction, with lateral and vertical variations in degree and conditions of alteration (i.e., temperature, redox, and fluid compo- sition). Overall, alteration at Shatsky Rise occurred under relatively low temperature and relatively oxidizing conditions, resulting in a slight to complete replacement of primary phases (glassy mesostasis, olivine, plagioclase, and pyroxene) by clay minerals (i.e., smectites). Calcite and pyrite are also common secondary minerals, replacing primary phases and filling vesicles, veins, and voids. Other alteration minerals at Shatsky Rise commonly include zeolites, rare hematite, and very rare chlorite.

Predominant alteration of Shatsky Rise basalts is a gray alteration, resulting from interaction of basalts with seawater-derived fluids under anoxic-suboxic conditions at low-temperature and low water-rock ratios. This alteration type was encountered at Sites U1346, U1347, and U1350 and affected the basalts to various degrees (from slight to high). Primary phases (olivine and glassy mesostasis) are commonly replaced by clay minerals (i.e., montmorillonite, nontronite, and saponite), whereas pyroxene and plagioclase are generally well preserved. Fresh titanomagnetite is also present in lava flow interiors at these sites when alteration degree is $<50 \%$. Significant fresh glass was commonly observed on flow and pillow margins of Holes U1347A and U1350A and more rarely in Hole U1346A. A predominance of calcite and pyrite at these sites also suggests interaction of the basalts with $\mathrm{CO}_{2}$ - and S-rich fluids.

Basalts recovered at Sites U1348 and U1349 differ in degrees and types of alteration. Hole U1348A recovered hyaloclastites in which glassy clasts were altered to palagonite and cemented by calcite and/or zeolite (i.e., phillipsite). Basalts recovered in Hole U1349A have been affected by extensive water-rock interaction, with variations in temperature and redox conditions with depth. Secondary low-temperature and oxidizing mineral assemblages, dominated by iddingsite, hematite, and calcite in the upper $205 \mathrm{mbsf}$ (Unit IV), change to relatively higher temperature secondary mineral assemblages composed of clay minerals, zeolite, minor chlorite, and rare serpentine below 205 mbsf. Unit IV in Hole U1349A shows evidence of subaerial weathering and of lavas being in very shallow water (e.g., hematite, nine horizons of intense red alteration interpreted as subaerially exposed flow tops, and thin interbedded oolitic limestone). This suggests that prior to typical low-temperature oxidizing seawater-rock interaction, basalts in Hole U1349A were first altered under subaerial oxidative tropical conditions.

\section{Geochemistry}

Alteration has modified the major and trace element compositions of virtually all igneous rocks analyzed during Expedition 324. Compositions of samples 
from Sites U1347 and U1350 have been affected the least overall (e.g., Fig. F11A). Interelement relationships indicate that the Site U1347 and U1350 rocks are variably evolved tholeiitic basalts. Similar to basalts from Site 1213 on the southern Tamu Massif, the compositions of the Site U1347 and U1350 lavas show some overlap with data for the OJP but are more similar in many elements to ocean-ridge basalts. More specifically, the Site U1347 lavas and many of the Site U1350 basalts resemble E-MORB. Some Site U1350 samples, particularly from the deeper part of the basement section, have relatively low $\mathrm{Zr} / \mathrm{Ti}$ ratios similar to those of normal oceanridge basalts. A broad generalization is that results for these sites on the whole suggest a source slightly richer in the more incompatible elements than normal ocean-ridge mantle and/or that the majority of magmas formed by slightly smaller amounts of partial melting than normal ridge basalts and possibly in the presence of residual garnet. Compared to the Site 1213 basalts, some of the Site U1347 and U1350 lavas show slightly greater enrichment in the more incompatible elements.

Seeing through the effects of alteration is a much greater challenge with samples from Sites U1346, U1348, and U1349. However, alteration-resistant elements, particularly $\mathrm{Zr}$ and $\mathrm{Ti}$, provide the following insights. All of these rocks are (or were originally) tholeiitic basalts. Those from Shirshov Massif Site U1346 are similar to the Site 1213 basalts, whereas the Site U1348 volcaniclastic rocks from the northern Tamu Massif are broadly similar to the lavas of Site U1347 (Fig. F11B). In addition to severe alteration, the compositions of basalts from Site U1349 atop the Ori Massif have been modified by variable accumulation of olivine and possibly clinopyroxene. Allowing for these effects, the Site U1349 samples appear to represent significantly less differentiated magmas than rocks from the other sites; they show compositional similarities with primitive oceanridge and Ontong Java basalts.

\section{Structure}

Primary structural elements observed in Expedition 324 cores include sediment bedding, conjugate joints, veins, breccias, and microfaults. In addition, synmagmatic structures, such as amygdules, vesicles, pipe vesicles, sheet flow structures, and interpillow and intrapillow structures, are also examined. Most veins are postmagmatic and were filled after lavas cooled. Most horizontal veins show syntaxial growth, cutting veins with other orientations, suggesting that horizontal contraction produced the syntaxial veins at a late stage of formation. Syntaxial veins in Holes U1349A and U1350A are more com- mon than those in other holes, possibly implying that Ori Massif experienced more contractional stress than Tamu and Shirshov massifs. The spatial distribution of joints and veins is complex in Shatsky Rise lavas. In general, dip angles of both veins and joints become gradually steeper downhole, except for Hole U1350A. The population of joints and/or veins possibly depends on the physical properties of the rocks. In all the holes, regular veins are commonly well developed in basalts with fine-grained groundmass and low vesicularity. Two primary synmagmatic structures, pillow and sheet flow structures, are common in all holes except for U1348A. At the other four sites, sequences of stacked pillow lavas whose sizes range from $\sim 20-200 \mathrm{~cm}$ or stacked sheet flows with sizes of up to $23 \mathrm{~m}$ were observed. Only the upper part of Hole U1349A implies subaerial eruption; rocks in all other cored sections are products of submarine eruptions.

\section{Paleomagnetism}

The goal of paleomagnetic studies during Expedition 324 was to characterize magnetic remanence of recovered igneous rocks. The majority of basalt samples showed low coercivity and blocking temperatures characteristic of titanomagnetite (-maghemite) with a range of Ti content. Overall, it was found that stable characteristic magnetization inclinations are shallow and mostly negative. However, several atypical behaviors were encountered and need to be addressed during postcruise research before interpreting the results. For example, in some stratigraphic units, many samples displayed irregular behavior during demagnetization experiments. Additionally, samples from Hole U1349A may show evidence of a chemical remanent magnetization (carried by hematite) instead of a thermoremanent magnetization (carried by titanomagnetite). In some samples, partial self-reversal of the magnetization may have occurred during the thermal demagnetization procedure. However, the overall results show shallow average inclinations at all sites, supporting the hypothesis that Shatsky Rise was formed near the paleomagnetic equator. Furthermore, the low scatter in stratigraphic-average inclination groups implies that at most sites, especially Sites U1347 (Tamu Massif) and U1346 (Shirshov Massif), little time passed during the eruption of igneous units (Fig. F27).

The only sedimentary measurements made during Expedition 324 were on the volcaniclastic sediments at Site U1348. Samples from this site show higher coercivity, consistent with single-domain titanomagnetite. The average stable magnetization inclinations from these samples are also low, implying low paleolatitude. Because these rocks are volcaniclastic sedi- 
ments, the inclinations are from a depositional remanent magnetization, rather than a thermal remanent magnetization as at other sites, that requires further measurements and interpretation.

\section{Physical properties}

Expedition 324 recovered igneous material that had experienced minimal to near-complete alteration, which naturally affected physical properties. Site U1346, atop the Shirshov Massif, and Site U1349, at the summit of the Ori Massif, exhibit the most extreme and variable alteration, which is reflected in their physical properties. Natural gamma radiation counts from ${ }^{40} \mathrm{~K}$ decay are three to four times higher in the altered material recovered at these sites versus the comparatively fresher material at Sites U1347 and U1350 (Fig. F28). Magnetic susceptibility displays distinct drops associated with oxidative alteration at both Sites U1346 and U1349. Cores from Hole U1349A are remarkable for the extent of oxidative alteration, suggested by the presence of hematite in Sections 324-U1349-7R-1 through 10R-5. In this interval, the magnetic susceptibility drops to levels ubiquitously $<1000 \times 10^{-5}$ SI (Fig. F29). Below the oxidative front, where hematite is no longer present, magnetic susceptibility is higher. An analogous relationship is seen in Hole U1346A, where the gray alteration has a higher magnetic susceptibility than the oxidative brown alteration. Another notable physical property in Hole U1346A is a distinct excursion in NGR from ${ }^{238} \mathrm{U}$ decay to values of almost 200 cps at 129.6-129.9 mbsf (Section 324-U1346-5R-1) in sedimentary material (Fig. F28).

In stark contrast to the altered material of Holes U1346A and U1349A, the comparatively fresh igneous rocks recovered in Holes U1347A and U1350A have low NGR counts ( $<5 \mathrm{cps})$ (Fig. F28). Coring in both Holes U1347A and U1350A recovered alternating pillow lavas and massive inflation flows with broadly similar physical properties. Discrete measurements yield densities of $2.32-3.23 \mathrm{~g} / \mathrm{cm}^{3}$, porosities of $0.17 \%-29.47 \%$, and $P$-wave velocities (with negligible anisotropy) of $3.04-7.08 \mathrm{~km} / \mathrm{s}$. Notable intervals include a massive flow unit (Cores 324U1347A-26R to 29R) at the bottom of Hole U1347A. This unit displayed the highest consistent readings of magnetic susceptibility, as well as cyclic magnetic susceptibility variations that might be used to decipher the chemical stratigraphy of the flow. Site U1350 was the most consistent with respect to downhole physical properties. Very little variation in density and only a slight downhole decrease in magnetic susceptibility was observed. Sedimentary interbeds were commonly observed in both Hole U1347A and U1350A cores and readily distinguished by their lower GRA bulk densities and magnetic susceptibility. The variations in density, porosity, and $P$-wave velocity measured on discrete samples were dominantly related to sampling bias (e.g., vesicularity) rather than lithologic differences.

Hole U1348A was quite different from the other sites in terms of its physical properties. Magnetic susceptibility values were $<110 \times 10^{-5}$ SI and GRA densities were lower compared to igneous material from other sites (Figs. F29, F30). GRA density was also notable for its smooth, gradual increase in individual stratigraphic units, plausibly related to compaction. The $P$-wave velocities were the lowest seen at any of the sites, with values ranging from 2.09 to $3.32 \mathrm{~km} / \mathrm{s}$ with an average of $2.78 \pm 0.79 \mathrm{~km} / \mathrm{s}(2 \sigma ; N=13)$. The volcanic rocks are also notable for their high porosity (all between 20\% and 40\%).

\section{Downhole logging}

Downhole logging data obtained during Expedition 324 included natural and spectral gamma ray, density, neutron porosity, PEF, electrical resistivity, and sonic measurements, as well as borehole formationoriented images from the FMS. Interpretation of gamma ray and electrical resistivity downhole logs was used to identify logging units at four sites. Data were recorded in sections covered by the BHA, in the sedimentary sequences in the open hole interval, and in the basaltic basement. The sedimentary sequences throughout the Shatsky Rise sites show prominent gamma ray anomalies associated with $\mathrm{U}$ and $\mathrm{K}$ enrichments. Some of the most prominent anomalies are found at the sediment/basement interface and in the most altered sites. The anomalies may be indicative of focused hydrothermal fluid flow, whereas shallower anomalies recorded through the BHA may correlate to oceanic anoxic events previously interpreted in this area. In several of the holes, high $\mathrm{K}$ content in the basement section also indicates a high degree of alteration compared to upper crustal sections previously drilled in other oceanic localities (Fig. F31). Electrical resistivity measurements in the basaltic basement show distinctive high-resistivity zones that likely represent massive flows and pillow flow units, interspersed with lowresistivity zones that mark sediment interbeds and highly altered zones. FMS images show zones of distinctive pillow lavas; zones with high fracture and vein densities; vesicular, brecciated, and volcaniclastic intervals; and intervals that represent massive lava flows, flow contacts, and variably dipping beds throughout the Shatsky Rise sites. 


\section{Preliminary scientific assessment}

\section{Plume versus plate}

Many of the Expedition 324 objectives relate to the ongoing debate about the source of volcanism and whether the plume head hypothesis explains oceanic plateau formation. To inform this debate, it is critical to know how quickly Shatsky Rise formed and what the source of the magmas was. Three primary objectives addressing these issues are: (1) to determine the basement age to constrain the temporal evolution of Shatsky Rise, (2) to determine chemical and isotopic compositions of igneous rocks, and (3) to determine the source temperature and degree of partial melting that produced the plateau lavas. Achieving these three primary objectives would directly address the aim of the cruise: "testing plume versus plate tectonic models of ocean plateau formation." In order to address the primary objectives, we planned to core as many basement lava flows as possible in the allocated time at five sites on the Shatsky Rise (Figs. F2, F3). Basement was penetrated at four of the five sites: U1346 (52.6 m basement penetration), U1347 (159.9 m basement penetration), U1349 (85.3 m basement penetration), and U1350 (172.7 m basement penetration). Although basement lavas were not encountered at Site U1348, a thick volcaniclastic sequence was penetrated $(\sim 120 \mathrm{~m})$ that can yield important data about submarine emplacement processes and weathering styles on Shatsky Rise.

To obtain reliable ${ }^{40} \mathrm{Ar} /{ }^{39} \mathrm{Ar}$ radiometric age data, the recovery of lavas of suitable freshness was crucial because submarine alteration can strongly modify the composition of rocks and seriously impact the K-Ar decay system. Shipboard petrographic studies and geochemical data from core samples from Sites U1347 and U1350 show that, in general, alteration has only slightly affected rocks from these sites, making them especially suitable for high-quality postcruise ${ }^{40} \mathrm{Ar} /{ }^{39} \mathrm{Ar}$ age determinations. The effects of alteration are more significant for most basement lavas from Sites U1346 and U1349, but some individual samples might be fresh enough to produce reliable age data given special treatment. Because basement lavas have been sampled from all three main massifs (Tamu, Ori, and Shirshov massifs), the age data will constrain the timing and duration of volcanism of the whole of Shatsky Rise and reveal whether the volcanism shows the expected age progression. Furthermore, with two sites each on Tamu and Ori massifs, it should be possible to determine whether each edifice was formed quickly, as expected for a plume head eruption, or over a longer time span, which would support less effusive, plate tectonics-related models.
Freshness of rock samples is also important for most chemical and isotopic studies, whose goals are to establish the original elemental compositions and isotopic characteristics of the rocks. Such data are crucial for determining the mantle source composition. Although the geochemical signature of any lowermantle source is debated, in general it is expected that mantle plumes give rise to igneous rocks with OIB-type isotopic characteristics and incompatible element ratios that indicate enrichment of highly incompatible elements in the magma source relative to the source of most MORB. The well-preserved lavas from Site U1347 and U1350 are particularly suitable for the determination of isotopic ratios and chemical compositions in postcruise studies. Such data will be important for inferring mantle source compositions. Although the effects of alteration are more severe for lavas from Sites U1346 and U1349, many individual samples from these sites appear suitable for most geochemical studies, particularly for investigations involving ratios of immobile incompatible elements and alteration-resistant isotope systems (e.g., Sm-Nd and Lu-Hf) and several other isotope systems provided special treatment of the samples (e.g., analyses of mineral separates or microanalyses by laser ablation techniques). Most important, large amounts of fresh volcanic glass were recovered in several intervals at Sites U1347, and U1350, and a small amount was found at Site U1346. Fresh glass was also found in a continuous interval within the volcaniclastic succession of Site U1348 (intervals 324-U1348A-23R$1,110-126 \mathrm{~cm}$, to $23 \mathrm{R}-2,1-8 \mathrm{~cm})$. The recovery of fresh glass gives us the opportunity to determine volatile and noble gas contents and to conduct a number of high-quality isotopic and chemical studies. If OIB chemistry is found in the glass and/or high ratios of ${ }^{3} \mathrm{He} /{ }^{4} \mathrm{He}$ (generally assumed to indicate lower mantle origin) in mineral separates, the plume model will be supported; conversely, if no evidence of lower-mantle involvement is found, the plate model will be strengthened.

In order to estimate source temperatures and the degree of partial melting, it was important to core relatively primitive rocks with olivine phenocrysts. Such rocks, called picritic basalts, were recovered at Site U1349, providing an opportunity to estimate source temperatures in detailed postcruise studies. Although the picritic basalts have suffered from severe alteration, as well as accumulation of olivine and clinopyroxene, they show compositional similarities with picritic basalts from the OJP (i.e., Kroenke-type basalts). If the estimated potential temperature and degree of melting indicate an abnormally hot mantle, plume models will be strengthened. On the other hand, if the estimated values are consistent with 
those of ambient mantle (i.e., MORB-source mantle), plate models will be supported. Another important result of this drilling expedition is the recovery of spinel crystals in Site U1346 and U1349 basalts. Because spinel is crystallized from relatively primitive magmas, onshore studies of its composition may provide important information on the degree of melting of the mantle source.

\section{Oceanic plateau evolution}

Whereas the primary objectives are directly related to each other, secondary objectives have a wider variety. Preliminary scientific assessments for the secondary objectives are described as follows.

\section{Determine the physical volcanology of Shatsky Rise eruptions.}

Expedition 324 recovered basement lavas from two summit sites (Sites U1346 and U1349) and two flank sites (Sites U1347 and U1350). Lava flows at both summit sites are characterized by high ( $>40 \mathrm{vol} \%$ ) vesicularity, implying that the eruptive environment was shallow marine or even subaerial. A subaerial eruption is likely for Site U1349 lavas because of the style of weathering and the recovery of a highly oxidized horizon, which is interpreted as a possible paleosol, directly above the highly vesiculated lavas. In contrast, lava flows encountered at the two flank sites are mainly pillow basalts and massive inflation units, frequently interbedded with volcaniclastic or marine sediment. One massive basalt unit at Site $\mathrm{U} 1347$ is a very thick $(\sim 23 \mathrm{~m})$ homogeneous lava flow, which shows similar characteristics to continental flood basalt flows. Both pillow and massive basalts were also found during OJP drilling (Mahoney et al., 2001). The exceptionally high basement recovery (for RCB drilling) at many sites (averaging 39\%-67\%, with many individual cores reaching $>90 \%$ ) will allow a detailed examination of flow unit distribution and emplacement. Together with planned postcruise structural geological investigations and age determinations from calcite veins, an integrated model for the volcanological evolution of the rise can be constructed.

\section{Determine the magnetic polarity of Tamu Massif and paleolatitude of Shatsky Rise.}

Sager and Han (1993) suggested that the magnetic anomaly of Tamu Massif was produced in a short period of time during a period of reversed magnetic polarity. Shipboard paleomagnetic study of a thick (159.9 $\mathrm{m}$ ) lava pile at Site U1347 implies that the entire succession has the same magnetic polarity, which supports the model of Sager and Han (1993).
Paleolatitude measurements of oriented samples from all sites lead us to conclude that Shatsky Rise was located on or near the paleoequator during eruption. Although these preliminary results need to be refined by further, more detailed postcruise studies, the general model of a very short term formation of the entire Shatsky Rise in a near-Equator position seem to hold.

\section{Determine paleodepths of Shatsky Rise.}

Seismic profiles of two massifs (Ori and Shirshov) show flat basement summits beneath the sediment cover, indicating wave erosion; although these massifs are all in $>2000 \mathrm{~m}$ water depth today. This fact may be explained by significant lithospheric uplift before/during Shatsky Rise formation and later subsidence below sea level as the massifs moved away from the magma source, consistent with the plume model (e.g., Ito and Clift, 1998). If we assume that all four basement sites (Sites U1346, U1347, U1349, and U1350) subsided at rates similar to normal oceanic lithosphere, their calculated original eruption depths would have been shallow marine or above sea level (Fig. F26). Furthermore, Expedition 324 provided a number of other observations that imply shallow submarine and/or subaerial eruption of Shatsky Rise. Benthic foraminifers in sediments immediately overlying the igneous basements imply shallow paleowater depths of $<500 \mathrm{~m}$ for Site U1346 and $<200 \mathrm{~m}$ for Site U1347. At Sites U1346, U1347, and U1349, sediments just above the basement are interpreted as shallow-water bioclastic sandstones with volcanic clasts. The high vesicularity ( $>40 \mathrm{vol} \%$ ) of basalts at two summit sites (U1346 and U1349) also indicate shallow submarine or subaerial eruption because erupted magma must have been oversaturated with water. Assuming that the primary water content of the magma was similar to that of MORB and OJP magmas $(<0.5 \mathrm{wt} \%)$, we estimate that the volatilization depth must have been $<300 \mathrm{~m}$ (Newman and Lowenstern, 2002). Assuming original eruption in shallow water (or in air) and taking into account the contribution of the sediment load (Crough, 1983), the estimated subsidence for the basement sites, except for Site U1350, is 3200-3400 m (Fig. F26). This value is in excellent agreement with the prediction (3000-3600 m subsidence) for 140-150 Ma normal oceanic lithosphere (Parsons and Sclater, 1997; Stein and Stein, 1992). Figure F26 also shows that Sites U1346, U1347, and U1349 were significantly shallower (2000-2500 m) during eruption time compared to normal mid-ocean ridges. Although an eruption depth for Site U1350 is undetermined so far, postcruise studies will determine dissolved $\mathrm{CO}_{2}$ content in the preserved fresh glass rims. Because of 
the strong pressure dependence of $\mathrm{CO}_{2}$ solubility in basaltic melts and because fresh glasses were recovered at almost all sites (U1346-U1348 and U1350), we can expect further constraints on the uplift and subsidence history of Shatsky Rise.

\section{Determine magma evolution and magma chamber processes at Shatsky Rise.}

In order to determine crustal magma chamber and magma evolution processes, lava samples from several evolutionary stages are desired (from less evolved, Mg-rich compositions to more differentiated, Mg-poor compositions). Expedition 324 recovered samples ranging from picritic basalts with high $\mathrm{MgO}$ contents (as much as $15.6 \mathrm{wt} \%$ ) to more differentiated tholeiitic basalts with low $\mathrm{MgO}$ contents (as little as $4.9 \mathrm{wt} \%)$. The picritic basalts were cored at Site U1349, and lower MgO tholeiitic basalts were sampled from the other three basement sites (U1346, U1347, and U1350). Phenocryst assemblages of the basement rocks correlate well with rock compositions; picritic basalts have only olivine phenocrysts with spinel inclusions and the tholeiitic basalts are olivine-bearing plagioclase-clinopyroxene-phyric basalts. This correlation will be further examined by more detailed postcruise studies, but it is expected that the recovered material is suitable to address magmatic evolutionary processes. For example, plagioclase phenocrysts with reverse zoning and oscillatory zoning are observed in several rocks from Sites U1347 and U1350. The zoning profiles will be investigated by postcruise studies and will help to constrain magma evolution processes.

\section{References}

Allègre, C.J., and Turcotte, D.L., 1985. Geodynamic mixing in the mesosphere boundary layer and the origin of oceanic islands. Geophys. Res. Lett., 12(4):207-210. doi:10.1029/GL012i004p00207

Anderson, D.L., 1995. Lithosphere, asthenosphere, and perisphere. Rev. Geophys., 33(1):125-149. doi:10.1029/ 94RG02785

Anderson, D.L., 2001. Top-down tectonics? Science, 293(5537):2016-2018. doi:10.1126/science.1065448

Anderson, D.L., 2005. Scoring hotspots; the plume and plate paradigms. In Foulger, G.R., Natland, J.H., Presnall, D.C., and Anderson, D.L. (Eds.), Plates, Plumes, and Paradigms. Spec. Pap.-Geol. Soc. Am., 388:31-54.

Anderson, D.L., and Natland, J.H., 2005. A brief history of the plume hypothesis and its competitors: concept and controversy. In Foulger, G.R., Natland, J.H., Presnall, D.C., and Anderson, D.L. (Eds.), Plates, Plumes, and Paradigms. Spec. Pap.—Geol. Soc. Am., 388:119-146.

Anderson, D.L., Tanimoto, T., and Zhang, Y.-S., 1992. Plate tectonics and hotspots: the third dimension. Science,
256(5064):1645-1651. doi:10.1126/sci-

ence.256.5064.1645

Bach, W., Hegner, E., Erzinger, J., and Satir, M., 1994. Chemical and isotopic variations along the superfast spreading East Pacific Rise from $6^{\circ} \mathrm{S}$ to $30^{\circ} \mathrm{S}$. Contrib. Mineral. Petrol., 116:365-380.

Bercovici, D., and Mahoney, J., 1994. Double flood basalts and plume head separation at the 660-kilometer discontinuity. Science, 266(5189):1367-1369. doi:10.1126/science.266.5189.1367

Brandon, A.D., Graham, D.W., Waight, T., and Gautason, B., 2007. ${ }^{186} \mathrm{Os}$ and ${ }^{187} \mathrm{Os}$ enrichments and high- ${ }^{3} \mathrm{He} /{ }^{4} \mathrm{He}$ sources in the Earth's mantle: evidence from Icelandic picrites. Geochim. Cosmochim. Acta, 71(18):4570-4591. doi:10.1016/j.gca.2007.07.015

Campbell, I.H., 1998. The mantle's chemical structure: insights from the melting products of mantle plumes. In Jackson, I. (Ed.), The Earth's Mantle: Composition, Structure, and Evolution: Cambridge (Cambridge Univ. Press), 259-310.

Coffin, M.F., and Eldholm, O., 1994. Large igneous provinces: crustal structure, dimensions, and external consequences. Rev. Geophys., 32(1):1-36. doi:10.1029/ 93RG02508

Coffin, M.F., Pringle, M.S., Duncan, R.A., Gladczenko, T.P., Storey, M., Müller, R.D., and Gahagan, L.A., 2002. Kerguelen hotspot magma output since $130 \mathrm{Ma}$. J. Petrol., 4(7)3:1121-1140. doi:10.1093/petrology/43.7.1121

Courtillot, V., Davaille, A., Besse, J., and Stock, J., 2003. Three distinct types of hotspots in Earth's mantle. Earth Planet. Sci. Lett., 205(3-4):295-308. doi:10.1016/S0012821X(02)01048-8

Crough, S.T., 1983. The correction for sediment loading on the seafloor. J. Geophys. Res., [Solid Earth], 88:6449-6454. doi:10.1029/JB088iB08p06449

Davaille, A., Le Bars, M. and Carbonne, C., 2003. Thermal convection in a heterogeneous mantle. C. R. Geosci., 335(1):141-156. doi:10.1016/S1631-0713(03)00003-8

Davaille, A., Stutzmann, E., Silveira, G., Besse, J., and Courtillot, V., 2005. Convective patterns under the IndoAtlantic "box." Earth Planet. Sci. Lett., 239(3-4):233-252. doi:10.1016/j.epsl.2005.07.024

Davies, G.F., 1992. Plates and plumes: dynamics of the earth's mantle. Science, 256(5069):493-494. doi:10.1126/science.257.5069.493

Den, N., Ludwig, W.J., Murauchi, S., Ewing, J.I., Hotta, H., Edgar, N.T., Yoshii, T., Asanuma, T., Hagiwara, K., Sato, T., and Ando, S., 1969. Seismic-refraction measurements in the northwest Pacific Basin. J. Geophys. Res., 74(6):1421-1434. doi:10.1029/JB074i006p01421

DePaolo, D.J., and Manga, M., 2003. Deep origin of hotspots-the mantle plume model. Science, 300(5621):920-921. doi:10.1126/science.1083623

Duncan, R.A., 2002. A time frame for construction of the Kerguelen Plateau and Broken Ridge. J. Petrol., 43(7):1109-1119. doi:10.1093/petrology/43.7.1109

Duncan, R.A., and Richards, M.A., 1991. Hotspots, mantle plumes, flood basalts, and true polar wander. Rev. Geophys., 29(1):31-50. doi:10.1029/90RG02372 
Eldholm, O., and Coffin, M.F., 2000. Large igneous provinces and plate tectonics. In Richards, M.A., Gordon, R.G., and van der Hilst, R.D. (Eds.), The History and Dynamics of Global Plate Motions. Geophys. Monogr., 121:309-326.

Ewing, M., Saito, T., Ewing, J.I., and Burckle, L.H., 1966. Lower Cretaceous sediments from the Northwest Pacific. Science, 152(3723):751-755. doi:10.1126/science.152.3723.751

Farnetani, C.G., and Samuel, H., 2005. Beyond the thermal plume paradigm. Geophys. Res. Lett., 32(7):L07311. doi:10.1029/2005GL022360

Fischer, A.G., Heezen, B.C., et al., 1971. Init. Repts. DSDP, 6: Washington, DC (U.S. Govt. Printing Office). doi:10.2973/dsdp.proc.6.1971

Fitton, J.G., and Godard, M., 2004. Origin and evolution of magmas on the Ontong Java Plateau. In Fitton, J.G., Mahoney, J.J., Wallace, P.J., and Saunders, A.D. (Eds.), Origin and Evolution of the Ontong Java Plateau. Geol. Soc. Spec. Publ., 229:151-178.

Fitton, J.G., Mahoney, J.J., Wallace, P.J., and Saunders, A.D., 2004. Leg 192 synthesis: origin and evolution of the Ontong Java Plateau. In Fitton, J.G., Mahoney, J.J., Wallace, P.J., and Saunders, A.D. (Eds.), Proc. ODP, Sci. Results, 192: College Station, TX (Ocean Drilling Program), 1-8. doi:10.2973/odp.proc.sr.192.101.2004

Foulger, G.R., 2002. Plumes, or plate tectonic processes? Astron. Geophys., 43(6):19-23.

Foulger, G.R., 2007. The "plate" model for the genesis of melting anomalies. In Foulger, G.R., and Jurdy, D.M. (Eds.), Plates, Plumes, and Planetary Processes. Spec. Pap.-Geol. Soc. Am., 430:1-28.

Foulger, G.R., and Anderson, D.L., 2005. A cool model for the Iceland hotspot. J. Volcanol. Geotherm. Res., 141(12):1-22. doi:10.1016/j.jvolgeores.2004.10.007

Foulger, G.R., and Natland, J.H., 2003. Is "hotspot" volcanism a consequence of plate tectonics? Science, 300(5621):921-922. doi:10.1126/science.1083376

Georgen, J.E., and Lin, J., 2002. Three-dimensional passive flow and temperature structure beneath oceanic ridgeridge-ridge triple junctions. Earth Planet. Sci. Lett., 204(1-2):115-132. doi:10.1016/S0012821X(02)00953-6

Gettrust, J.F., Furukawa, K., and Kroenke, L.W., 1980. Crustal structure of the Shatsky Rise from seismic refraction measurements. J. Geophys. Res., [Solid Earth], 85:5411-5415. doi:10.1029/JB085iB10p05411

Glen, W., 2005. The origins and early trajectory of the mantle plume quasi-paradigm. In Foulger, G.R., Natland, J.H., Presnall, D.C., and Anderson, D.L. (Eds.), Plates, Plumes, and Paradigms. Spec. Pap.-Geol. Soc. Am., 388:91-117.

Gradstein, F.M., Ogg, J.G., and Smith, A. (Eds.), 2004. A Geologic Time Scale 2004: Cambridge (Cambridge Univ. Press). http://www.stratigraphy.org/

Griffiths, R.W., and Campbell, I.H., 1990. Stirring and structure in mantle starting plumes. Earth Planet. Sci. Lett., 99(1-2):66-78. doi:10.1016/ 0012-821X(90)90071-5
Griffiths, R.W., and Campbell, I.H., 1991. Interaction of mantle plume heads with the earth's surface and onset of small-scale convection. J. Geophys. Res., [Solid Earth], 96(B11):18295-18310. doi:10.1029/91JB01897

Herzberg, C., Asimov, P.D., Arndt, N., Niu, Y., Lesher, C.M., Fitton, J.G., Cheadle, M.J., and Saunders, A.D., 2007. Temperatures in ambient mantle and plumes: constraints from basalts, picrites, and komatiites. Geochem., Geophys., Geosyst., 8(2):Q02006. doi:10.1029/ 2006GC001390

Hilde, T.W.C., Isezaki, N., and Wageman, J.M., 1976. Mesozoic sea-floor spreading in the North Pacific. In Woolard, G.P., Sutton, G.H., Manghnani, M.H., and Moberly, R. (Eds.), The Geophysics of the Pacific Ocean Basin and its Margins. Geophys. Monogr., 19:205-226.

Hildebrand, A.R., and Boynton, W.V., 1990. Proximal Cretaceous-Tertiary boundary impact deposits in the Caribbean. Science, 248(4957):843-847. doi:10.1126/ science.248.4957.843

Hoernle, K., Hauff, F., and van den Bogaard, P., 2004. 70 m.y. history (139-69 Ma) for the Caribbean large igneous province. Geology, 32(8):697-700. doi:10.1130/ G20574.1

Ingle, S., and Coffin, M., 2004. Impact origin of the greater Ontong Java Plateau? Earth Planet. Sci. Lett., 218(12):123-134. doi:10.1016/S0012-821X(03)00629-0

Ito, G., and Clift, P.D., 1998. Subsidence and growth of Pacific Cretaceous plateaus. Earth Planet. Sci. Lett., 161(1-4):85-100. doi:10.1016/S0012-821X(98)001393

Ishikawa, A., Nakamura, E., and Mahoney, J.J., 2005. Jurassic oceanic lithosphere beneath the southern Ontong Java Plateau: evidence from xenoliths in alnöite, Malaita, Solomon Islands. Geology, 33(5):393-396. doi:10.1130/G21205.1

Janney, P.E., and Castillo, P.R., 1999. Isotope geochemistry of the Darwin Rise seamounts and the nature of longterm mantle dynamics beneath the south central Pacific. J. Geophys. Res., [Solid Earth], 104(B5):10,57110,589. doi:10.1029/1998JB900061

Johnson, S.T., and Thorkelson, D.J., 2000. Continental flood basalts: episodic magmatism above long-lived hotspots. Earth Planet. Sci. Lett., 175(3-4):247-256. doi:10.1016/S0012-821X(99)00293-9

Kellogg, L.H., Hager, B.H., and van der Hilst, R.D., 1999. Compositional stratification in the deep mantle. Science, 283(5409):1881-1884. doi:10.1126/science.283.5409.1881

Klaus, A., and Sager, W.W., 2002. Data report: high-resolution site survey seismic reflection data for ODP Leg 198 drilling on Shatsky Rise, northwest Pacific. In Bralower, T.J., Premoli Silva, I., Malone, M.J., et al., Proc. ODP, Init. Repts., 198: College Station, TX (Ocean Drilling Program), 1-21. doi:10.2973/odp.proc.ir.198.111.2002

Kleinrock, M.C., and Phipps Morgan, J., 1988. Triple junction reorganization. J. Geophys. Res., 93(B4):2981-2996. doi:10.1029/JB093iB04p02981

Koppers, A.A.P., Staudigel, H., Pringle, M.S., and Wijbrans, J.R., 2003. Short-lived and discontinuous intraplate volcanism in the South Pacific: hot spots or extensional 
volcanism? Geochem., Geophys., Geosyst., 4(10):1089. doi:10.1029/2003GC000533

Larson, R.L., 1991. Latest pulse of Earth: evidence for a mid-Cretaceous super plume. Geology, 19(6):547-550. doi:10.1130/0091-

7613(1991)019<0547:LPOEEF>2.3.CO;2

Larson, R.L., and Chase, C.G., 1972. Late Mesozoic evolution of the western Pacific Ocean. Geol. Soc. Am. Bull., 83(12):3627-3644. doi:10.1130/

0016-7606(1972)83[3627:LMEOTW]2.0.CO;2

Larson, R.L., Pockalny, R.A., Viso, R.F., Erba, E., Abrams, L.J., Luyendyk, B.P., Stock, J.M., and Clayton, R.W., 2002. Mid-Cretaceous tectonic evolution of the Tongareva triple junction in the southwestern Pacific Basin. Geology, 30(1):67-70. doi:10.1130/0091-

7613(2002)030<0067:MCTEOT>2.0.CO;2

Lassiter, J.C., Blichert-Toft, J., Hauri, E.H., and Barsczus, H.G., 2003. Isotope and trace element variations in lavas from Raivavae and Rapa, Cook-Austral islands: constraints on the nature of HIMU- and EM-mantle and the origin of mid-plate volcanism in French Polynesia. Chem. Geol., 202(1-2):115-138. doi:10.1016/j.chemgeo.2003.08.002

Le Maitre, R.W., Bateman, P., Dudek, A., Keller, J., Lameyre, J., Le Bas, M.J., Sabine, P.A., Schmid, R., Sorensen, H., Streckeisen, A., Woolley, A.R., and Zanettin, B., 1989. A Classification of Igneous Rocks and Glossary of Terms: Oxford (Blackwell).

Lin, S.-C., and van Keken, P.E., 2006a. Dynamics of thermochemical plumes: 1 . Plume formation and entrainment of a dense layer. Geochem., Geophys., Geosyst., 7(2):Q02006. doi:10.1029/2005GC001071

Lin S.-C., and van Keken, P.E., 2006b. Dynamics of thermochemical plumes: 2. Complexity of plume structures and its implications for mapping mantle plumes. Geochem., Geophys., Geosyst.,7(3):Q03003. doi:10.1029/ 2005GC001072

Ludwig, W.J., and Houtz, R.E., 1979. Isopach Map of Sediments in the Pacific Ocean Basin and Marginal Sea Basins. AAPG Map Ser., 647.

Lithgow-Bertelloni, C., and Richards, M.A., 1998. The dynamics of Cenozoic and Mesozoic plate motions. Rev. Geophys., 36(1):27-78. doi:10.1029/97RG02282

Macdonald, G.A., 1968. Composition and origin of Hawaiian lavas. In Coats, R.R., Hay, R.L., and Anderson, C.A. (Eds.), Studies in Volcanology: A Memoir in Honor of Howel Williams. Mem.-Geol. Soc. Am., 116:477-522.

Macdonald, G.A., and Katsura, T., 1964. Chemical composition of Hawaiian lavas. J. Petrol., 5:82-133.

Machetel, P., and Humler, E., 2003. High mantle temperature during Cretaceous avalanche. Earth Planet. Sci. Lett., 208(3-4):125-133. doi:10.1016/S0012-821X(03)000414

Mahoney, J.J., Duncan, R.A., Tejada, M.L.G., Sager, W.W., and Bralower, T.J., 2005. Jurassic-Cretaceous boundary age and mid-ocean-ridge-type mantle source for Shatsky Rise. Geology, 33(3):185-188. doi:10.1130/ G21378.1
Mahoney, J.J., Fitton, J.G., Wallace, P.J., et al., 2001. Proc. ODP, Init. Repts., 192: College Station, TX (Ocean Drilling Program). doi:10.2973/odp.proc.ir.192.2001

Mahoney, J.J., Sinton, J.M., Kurz, M.D., Macdougall, J.D., Spencer, K.J., and Lugmair, G.W., 1994. Isotope and trace element characteristics of a super-fast spreading ridge: East Pacific Rise $13-23^{\circ}$ S. Earth Planet. Sci. Lett., 121(1-2):173-193. doi:10.1016/ 0012-821X(94)90039-6

Mahoney, J.J., and Spencer, K.J., 1991. Isotopic evidence for the origin of the Manihiki and Ontong Java oceanic plateaus. Earth Planet. Sci. Lett., 104(2-4):196-210. doi:10.1016/0012-821X(91)90204-U

Mahoney, J.J., Storey, M., Duncan, R.A., Spencer, K.J., and Pringle, M.S., 1993. Geochemistry and age of the Ontong Java Plateau. In Pringle, M.S., Sager, W.W., Sliter, W.V., and Stein, S. (Eds.), The Mesozoic Pacific: Geology, Tectonics, and Volcanism. Geophys. Monogr., 77:233-262.

McNutt, M.K., and Fischer, K.M., 1987. The South Pacific superswell. In Keating, B.H., Fryer, P., Batiza, R., and Boehlert, G.W. (Eds.), Seamounts, Islands, and Atolls. Geophys. Monogr., 43:25-34.

Morgan, W.J., 1971. Convection plumes in the lower mantle. Nature (London, U. K.), 230(5288):42-43. doi:10.1038/230042a0

Morgan, W.J., 1972. Deep mantle convection plumes and plate motions. AAPG Bull., 56:203-213.

Morgan, W.J., 1981. Hotspot tracks and the opening of the Atlantic and Indian Oceans. In Emiliani, C. (Ed.), The Sea (Vol. 7): New York (Wiley), 443-487.

Nakanishi, M., Sager, W.W., and Klaus, A., 1999. Magnetic lineations within Shatsky Rise, northwest Pacific Ocean: implications for hot spot-triple junction interaction and oceanic plateau formation. J. Geophys. Res., 104(B4):7539-7556. doi:10.1029/1999JB900002

Nakanishi, M., Tamaki, K., and Kobayashi, K., 1989. Mesozoic magnetic anomaly lineations and seafloor spreading history of the northwestern Pacific. J. Geophys. Res., 94(B11):15437-15462. doi:10.1029/JB094iB11p15437

Natland, J.H., and Winterer, E.L., 2005. Lithospheric stresses, great fissures, and volcanism at seamounts and plateaus in the Pacific since the Jurassic. In Foulger, G.R., Natland, J.H., Presnall, D.C., and Anderson, D.L. (Eds.), Plates, Plumes, and Paradigms. Spec. Pap.-Geol. Soc. Am., 388:687-710.

Neprochnov, Y.P., Merklin, L.R., and Khankishiyeva, L.M., 1984. Distribution map of the sedimentary cover on the Shatsky Rise. Dokl. Akad. Nauk SSSR, 277(5):1204-1207.

Newman, S., and Lowenstern, J.B., 2002. VolatileCalc: a silicate melt $-\mathrm{H}_{2} \mathrm{O}-\mathrm{CO}_{2}$ solution model written in Visual Basic for Excel. Comput. Geosci., 28(5):597-604. doi:10.1016/S0098-3004(01)00081-4

Olson, P., and Nam, I.S., 1986. Formation of seafloor swells by mantle plumes. J. Geophys. Res., [Solid Earth], 91:7181-7191. doi:10.1029/JB091iB07p07181

Parsons, B., and Sclater, J.G., 1977. An analysis of the variation of ocean floor bathymetry and heat flow with age. J. Geophys. Res., [Solid Earth], 82:803-827. doi:10.1029/ JB082i005p00803 
Putirka, K, 2008. Excess temperatures at ocean islands: implications for mantle layering and convection. Geology, 36(4):283-286. doi:10.1130/G24615A.1

Ray, J.R., Mahoney, J.J., Duncan, R.A., Ray, J.S., Wessel, P., and Naar, D., submitted. Chronology and geochemistry of the Nazca Ridge and Easter Seamount Chain: a 30 Myr hotspot record. J. Petrol.

Ray, J.S., Mahoney, J.J., Johnson, K.T.M., Pyle, D.G., Naar, D., and Wessel, P., 2003. Geochemistry of volcanism along the Nazca Ridge and Easter Seamount Chain [EGS-AGU-EUG Joint Assembly, Nice, 06-11 April 2003].

Richards, M.A., Duncan, R.A., and Courtillot, V.E., 1989. Flood basalts and hot-spot tracks: plume heads and tails. Science, 246(4926):103-107. doi:10.1126/science.246.4926.103

Roddy, D.J., Schuster, S.H., Rosenblatt, M., Grant, L.B., Hassig, P.J., and Kreyenhagen, K.N., 1987. Computer simulations of large asteroid impacts into oceanic and continental sites-preliminary results on atmospheric, cratering and ejecta dynamics. Int. J. Impact Eng., 5(14):525-541. doi:10.1016/0734-743X(87)90068-6

Rogers, G.C., 1982. Oceanic plateaus as meteorite impact signatures. Nature (London, U. K.), 299(5881):341-342. doi:10.1038/299341a0

Roberge, J., Wallace, P.J., White, R.V., and Coffin, M.F., 2005. Anomalous uplift and subsidence of the Ontong Java Plateau inferred from $\mathrm{CO}_{2}$ contents of submarine basaltic glasses. Geology, 33(6):501-504. doi:10.1130/ G21142.1

Sager, W.W., 2005. What built Shatsky Rise, a mantle plume or ridge processes? In Foulger, G.R., Natland, J.H., Presnall, D.C., and Anderson, D.L. (Eds.), Plates, Plumes, and Paradigms. Spec. Pap.-Geol. Soc. Am., 388:721733.

Sager, W.W., and Han, H.-C., 1993. Rapid formation of the Shatsky Rise oceanic plateau inferred from its magnetic anomaly. Nature (London, U. K.), 364(6438):610-613. doi:10.1038/364610a0

Sager, W.W., Handschumacher, D.W., Hilde, T.W.C., and Bracey, D.R., 1988. Tectonic evolution of the northern Pacific plate and Pacific-Farallon Izanagi triple junction in the Late Jurassic and Early Cretaceous (M21-M10). Tectonophysics, 155(1-4):345-364. doi:10.1016/00401951(88)90274-0

Sager, W.W., Kim, J., Klaus, A., Nakanishi, M., and Khankishieva, L.M., 1999. Bathymetry of Shatsky Rise, northwest Pacific Ocean: implications for ocean plateau development at a triple junction. J. Geophys. Res., [Solid Earth], 104(4):7557-7576. doi:10.1029/1998JB900009

Sandwell, D.T., and MacKenzie, K.R., 1989. Geoid height versus topography for oceanic plateaus and swells. $J$. Geophys. Res., [Solid Earth], 94:7403-7418. doi:10.1029/ JB094iB06p07403

Shipboard Scientific Party, 2002a. Leg 198 summary. In Bralower, T.J., Premoli Silva, I., Malone, M.J., et al., Proc. ODP, Init. Repts., 198: College Station, TX (Ocean Drilling Program), 1-148. doi:10.2973/ odp.proc.ir.198.101.2002
Shipboard Scientific Party, 2002b. Site 1213. In Bralower, T.J., Premoli Silva, I., Malone, M.J., et al., Proc. ODP, Init. Repts., 198: College Station, TX (Ocean Drilling Program), 1-110. doi:10.2973/odp.proc.ir.198.109.2002

Sinton, J.M., Smaglik, S.M., Mahoney, J.J., and Macdonald, K.C., 1991. Magmatic processes at superfast spreading mid-ocean ridges: glass compositional variations along the East Pacific Rise $13^{\circ}-23^{\circ}$ S. J. Geophys. Res., [Solid Earth], 96:6133-6155. doi:10.1029/90JB02454

Sleep, N.H., 2003. Mantle plumes? Astron. Geophys., 44(1):1.11-1.13. doi:10.1046/j.14684004.2003.44111.x

Sleep, N.H., 2007. Plate tectonics through time. Treatise Geophys., 9:145-169. doi:10.1016/B978-044452748-6/ 00143-7

Sliter, W.V., and Brown, G.R., 1993. Shatsky Rise: seismic stratigraphy and sedimentary record of Pacific paleoceanography since the Early Cretaceous. In Natland, J.H., Storms, M.A., et al., Proc. ODP, Sci. Results, 132: College Station, TX (Ocean Drilling Program), 3-13. doi:10.2973/odp.proc.sr.132.302.1993

Smith, A.D., 2003. The regular distribution of intraplate volcanism in the Pacific Basin [Penrose Conference, Plume IV: Beyond the Plume Hypothesis, Hveragerdi, Iceland, 25-29 August 2003].

Smith, A.D., 2007. A plate model for Jurassic to recent intraplate volcanism in the Pacific Ocean Basin. In Foulger, G.R., and Jurdy, D.M. (Eds.), Plates, Plumes and Planetary Processes. Spec. Pap.-Geol. Soc. Am., 430:471495.

Smith, A.D., and Lewis, C., 1999. The planet beyond the plume hypothesis. Earth Sci. Rev., 48(3):135-182. doi:10.1016/S0012-8252(99)00049-5

Smith, W.H.F., and Sandwell, D.T., 1997. Global seafloor topography from satellite altimetry and ship depth soundings. Science, 277:1956-1962. doi:10.1126/science.277.5334.1956

Staudigel, H., Park, K.-H., Pringle, M., Rubenstone, J.L., Smith, W.H.F., and Zindler, A., 1991. The longevity of the South Pacific isotopic and thermal anomaly. Earth Planet. Sci. Lett., 102(1):24-44. doi:10.1016/ 0012-821X(91)90015-A

Stein, M., and Hofmann, A.W., 1994. Mantle plumes and episodic crustal growth. Nature (London, U. K.), 372(6501):63-68. doi:10.1038/372063a0

Stein, C.A., and Stein, S., 1992. A model for the global variation in oceanic depth and heat flow with lithospheric age. Nature (London, U. K.), 359(6391):123-129. doi:10.1038/359123a0

Sun, S.-S., and McDonough, W.F., 1989. Chemical and isotopic systematics of oceanic basalts: implications for mantle composition and processes. In Saunders, A.D., and Norry, M.J. (Eds.), Magmatism in the Ocean Basins. Geol. Soc. Spec. Publ., 42(1):313-345. doi:10.1144/ GSL.SP.1989.042.01.19

Tackley, P.J., Stevenson, D.J., Glatzmaier, G.A., and Schubert, G., 1993. Effects of an endothermic phase transition at $670 \mathrm{~km}$ depth in a spherical model of convection in the earth's mantle. Nature (London, U. K.), 361(6414):699-704. doi:10.1038/361699a0 
Tarduno, J.A., Sliter, W.V., Kroenke, L., Leckie, M., Mayer, H., Mahoney, J.J., Musgrave, R., Storey, M., and Winterer, E.L., 1991. Rapid formation of Ontong Java Plateau by Aptian mantle plume volcanism. Science, 254(5030):399-403. doi:10.1126/science.254.5030.399

Tatsumi, Y., Shinjoe, H., Ishizuka, H., Sager, W.W., and Klaus, A., 1998. Geochemical evidence for a mid-Cretaceous superplume. Geology, 26(2):151-154. doi:10.1130/ 0091-7613(1998)026<0151:GEFAMC >2.3.CO;2

Tejada, M.L.G., 1998. Geochemical studies of Pacific oceanic plateaus: the Ontong Java Plateau and Shatsky Rise [Ph.D. dissert.]. Univ. Hawaii, Honolulu.

Tejada, M.L.G., Mahoney, J.J., Castillo, P.R., Ingle, S.P., Sheth, H.C., and Weis, D., 2004. Pin-pricking the elephant: evidence on the origin of the Ontong Java Plateau from Pb-Sr-Hf-Nd isotopic characteristics of ODP Leg 192 basalts. In Fitton, J.G., Mahoney, J.J., Wallace, P.J., and Saunders, A.D. (Eds.), Origin and Evolution of the Ontong Java Plateau. Geol. Soc. Spec. Publ., 229:133-150.

Tejada, M.L.G., Mahoney, J.J., Duncan, R.A., and Hawkins, M.P., 1996. Age and geochemistry of basement and alkalic rocks of Malaita and Santa Isabel, Solomon Islands, southern margin of Ontong Java Plateau. J. Petrol. 37(2):361-394. doi:10.1093/petrology/37.2.361

Tejada, M.L.G., Mahoney, J.J., Neal, C.R., Duncan, R.A., and Petterson, M.G., 2002. Basement geochemistry and geochronology of Central Malaita, Solomon Islands, with implications for the origin and evolution of the
Ontong Java Plateau. J. Petrol., 43(3):449-484. doi:10.1093/petrology/43.3.449

Tominaga, M., Sager, W.W., and Channell, J.E.T., 2005. Paleomagnetism of the igneous section, Hole 1213B, Shatsky Rise. In Bralower, T.J., Premoli Silva, I., and Malone, M.J. (Eds.), Proc. ODP., Sci. Results, 198: College Station, TX (Ocean Drilling Program),1-15. doi:10.2973/odp.proc.sr.198.113.2005

Wallace, P.J., 2002. Volatiles in submarine basaltic glasses from the Northern Kerguelen Plateau (ODP Site 1140): implications for source region compositions, magmatic processes, and plateau subsidence. J. Petrol., 43(7):13111326. doi:10.1093/petrology/43.7.1311

White, R., and McKenzie, D., 1989. Magmatism at rift zones: the generation of volcanic continental margins and flood basalts. J. Geophys. Res., [Solid Earth], 94(B6):7685-7729. doi:10.1029/JB094iB06p07685

Whitehead, J.A., and Luther, D.S., 1975. Dynamics of laboratory diapir and plume models. J. Geophys. Res., [Solid Earth], 80(5):705-717. doi:10.1029/JB080i005p00705

Wilson, J.T., 1963. A possible origin of the Hawaiian Islands. Can. J. Phys., 41:863-870.

Winterer, E.L., 1976. Anomalies in the tectonic evolution of the Pacific. In Sutton, G.H., Manghnani, M.H., and Moberly, R. (Eds.), The Geophysics of the Pacific Ocean Basin and its Margin. Geophys. Monogr., 19:269-278.

Publication: 3 November 2010 MS 324-101 
Figure F1. Location of Shatsky Rise and other features in the northwest Pacific Ocean. Red circles = Expedition 324 drill sites, yellow line $=$ track of the JOIDES Resolution .




Figure F2. Location chart of major feature names (blue), the Cruise TN037 site survey seismic tracks, Cruise TN037 dredges, DSDP and ODP drill sites, and sites drilled during Expedition 324. Light blue shading = elevations shallower $5 \mathrm{~km}$ on Shatsky Rise. Site 1213 is the location where igneous rocks were drilled during ODP Leg 198 (Shipboard Scientific Party, 2002a). Inset illustrates the location of Shatsky Rise in relation to western Pacific magnetic lineations (thin lines), trenches (toothed line), and Japan.




Figure F3. Magnetic lineations within and around Shatsky Rise and Expedition 324 sites (red circles). Heavy red lines $=$ magnetic lineations and fracture zones, open circles $=$ prior drill sites, blue circle $=$ location of Site 1213. Satellite-predicted bathymetry (Smith and Sandwell, 1997) contours shown at $500 \mathrm{~m}$ intervals. Modified from Nakanishi et al. (1999).

\section{Shatsky Rise}

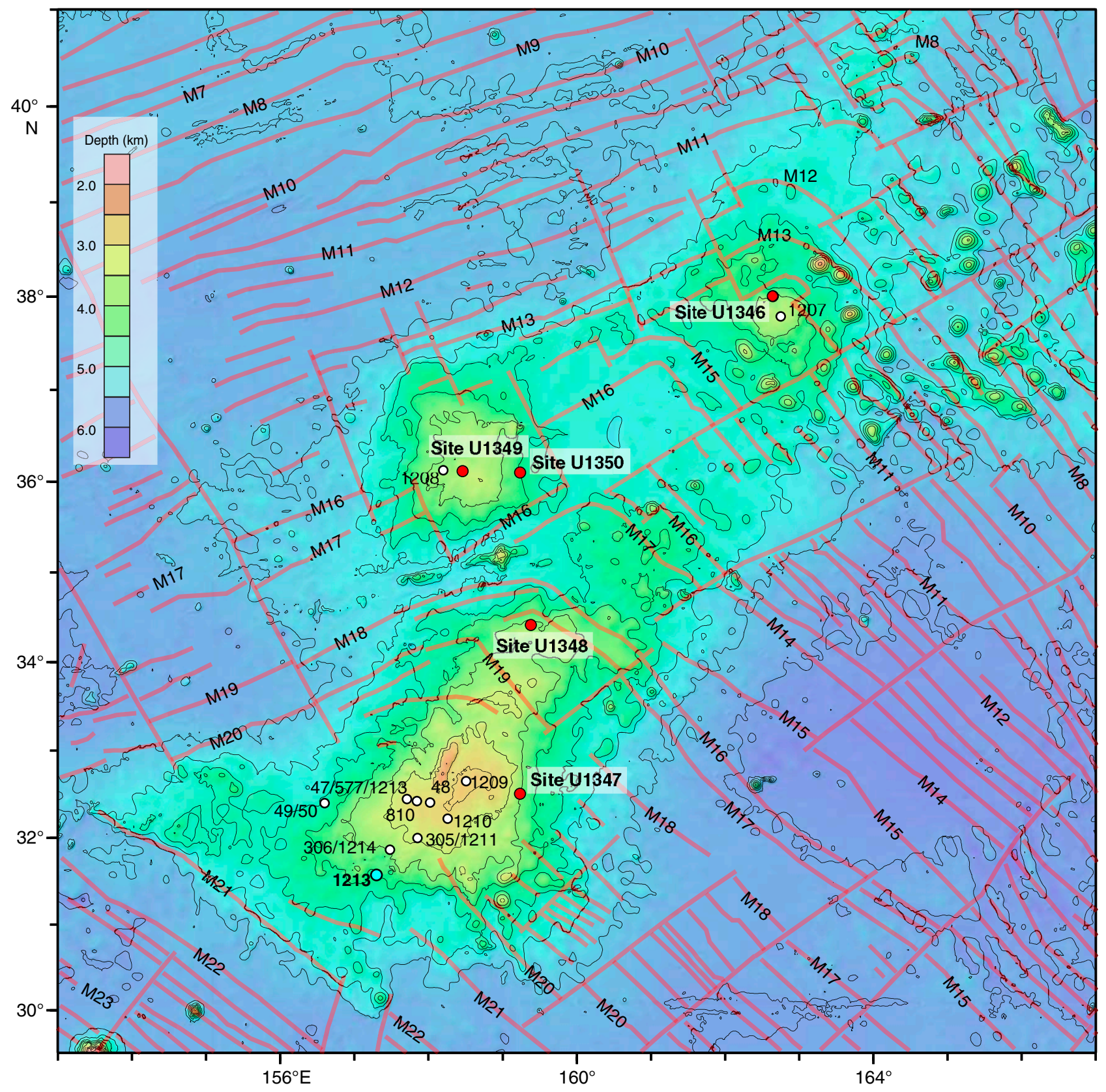


Figure F4. Tectonic history of Shatsky Rise, illustrating the migration of ridges and triple junctions (TJ) during formation of the rise. Dark magnetic lineations existed on the Pacific plate at the time given for each panel. Red lines $=$ ridges, light purple lines $=$ future isochrons, blue arrows $=$ path of triple junction, yellow arrows $=$ jumps and changes in direction (modified from Nakanishi et al., 1999).

M22 time (151 Ma) Tithonian

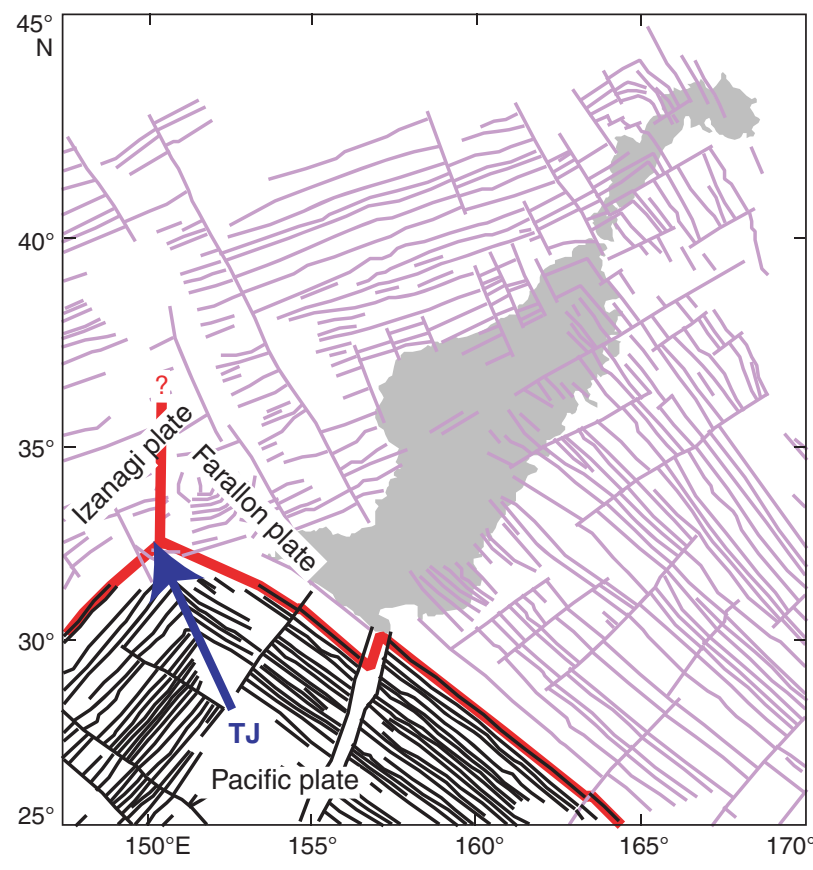

M13 time (139 Ma) Valanginian



M17 time (144 Ma) Jurassic/Cretaceous boundary

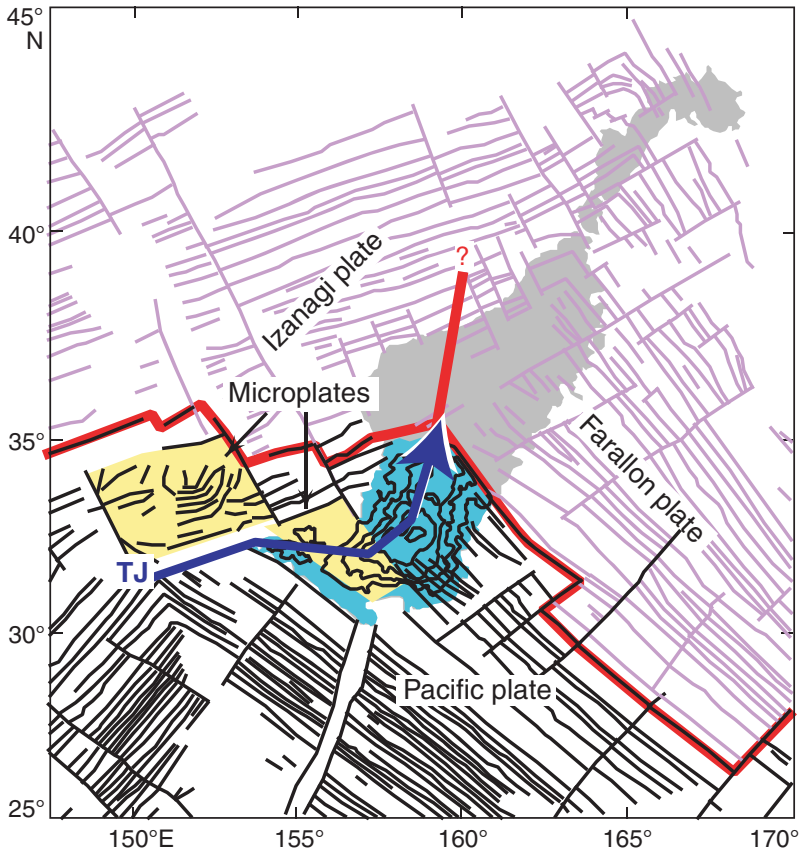

M5 time (131 Ma) Barremian

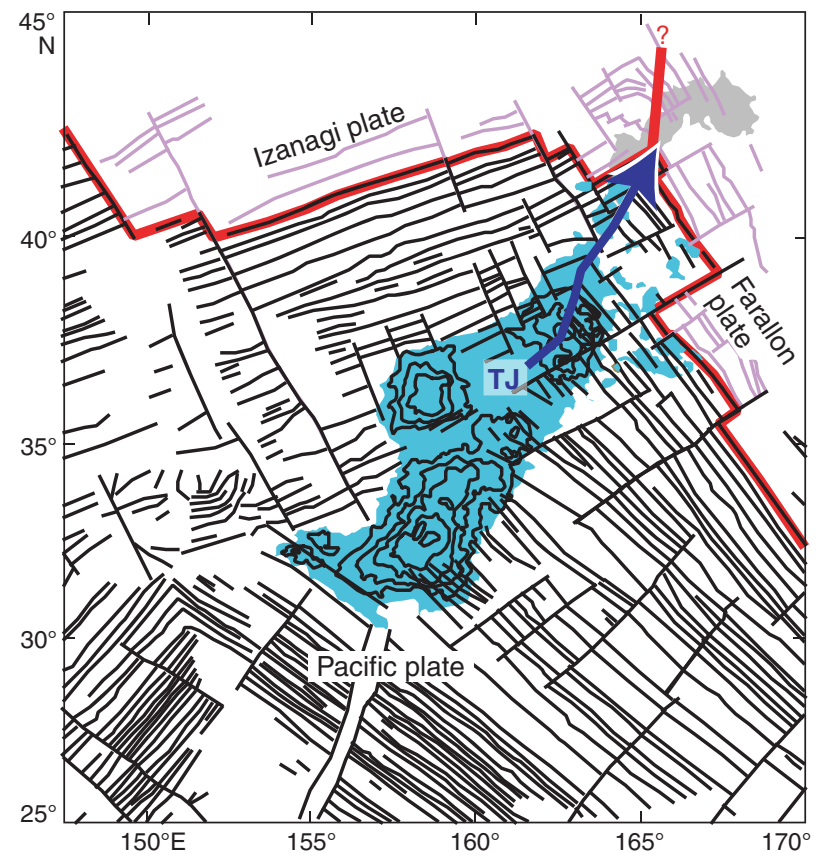


Figure F5. A. Age-corrected isotope data. Fields for Pacific mid-ocean-ridge basalt (MORB) and the Easter-Nazca Ridge hotspot chain are adjusted for radiogenic ingrowth to the estimated 144 Ma positions of the mantle sources (see Tejada et al., 2004). Pb isotope data for Holes 1213B and 1179D (and Easter-Nazca Ridge) were acquired using a double spike. Fields are from Mahoney and Spencer (1991), Tejada et al. (2004), Ray et al. (2003), and references therein (after Mahoney et al., 2005). SOTW = Southtow Expedition. B. Incompatible element diagram for Site 1213 samples compared with Ontong Java and mid-ocean-ridge basalt (MORB). Ontong Java pattern is from Fitton and Godard (2004); average normalized-MORB (N-MORB) pattern and normalizing values are from Sun and McDonough (1989) (after Mahoney et al., 2005).

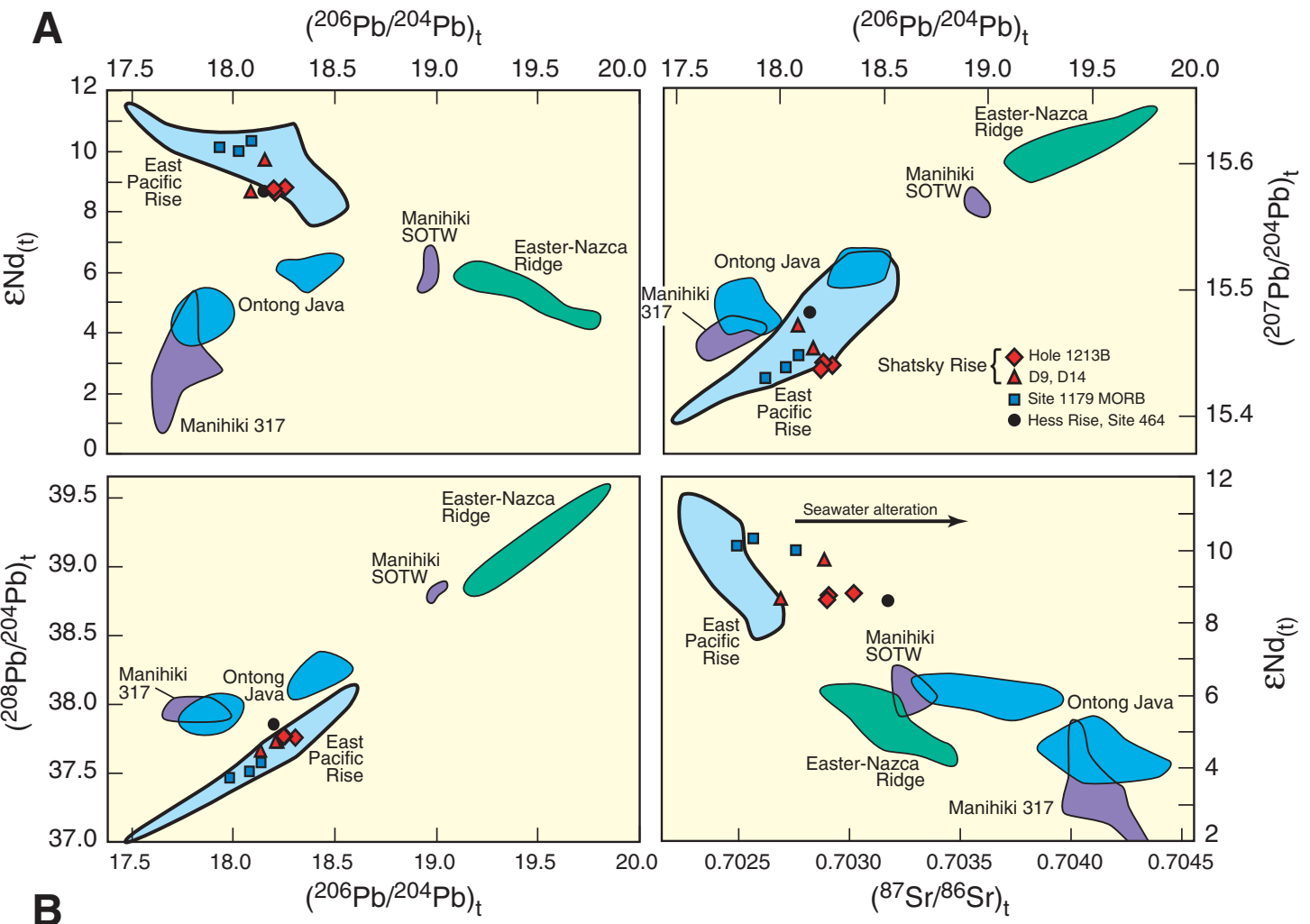

B




Figure F6. Bathymetry of Shirshov Massif and location of Site U1346. Contours and colors indicate bathymetric depths predicted by satellite altimetry (Smith and Sandwell, 1997). Site 1207 was cored during ODP Leg 198 (Shipboard Scientific Party, 2002a). Contours shown at $200 \mathrm{~m}$ intervals; dark contours shown for kilometer multiples. Red line $=$ track of Cruise TN037 site survey (Klaus and Sager, 2002).

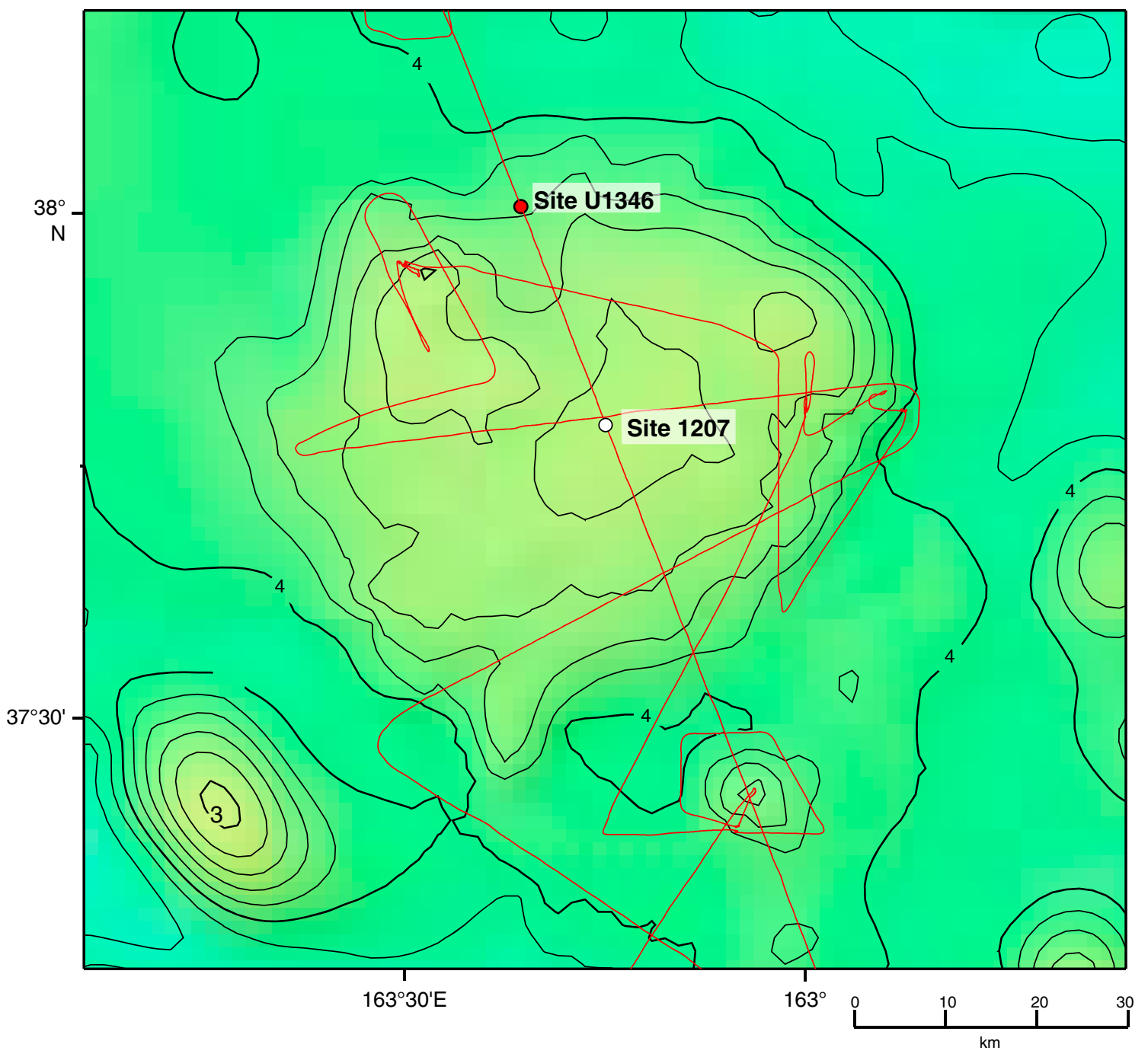


Figure F7. Seismic section and interpretation, Site U1346. See Klaus and Sager (2002). UTC = Universal Time Coordinated.




Figure F8. Overview of lithostratigraphy above igneous basement, Expedition 324. Sites arranged from left to right in geographical order. Age deduced from biostratigraphy indicated to the right of each column. Sites are arranged vertically to suggest general relative distribution of ages at all sites (see "Paleontology" in the "Methods" chapter). Early Cretaceous = Berriasian to Albian, Late Cretaceous = Cenomanian to Campanian, Cen $=$ middle Cenozoic. Note hiatus or lack of recovery between Campanian and middle Cenozoic at Site U1348. Gray shaded area = gap between last datable sediment and top of igneous basement (or top of the volcaniclastic sequence, Unit III, at Site U1348).

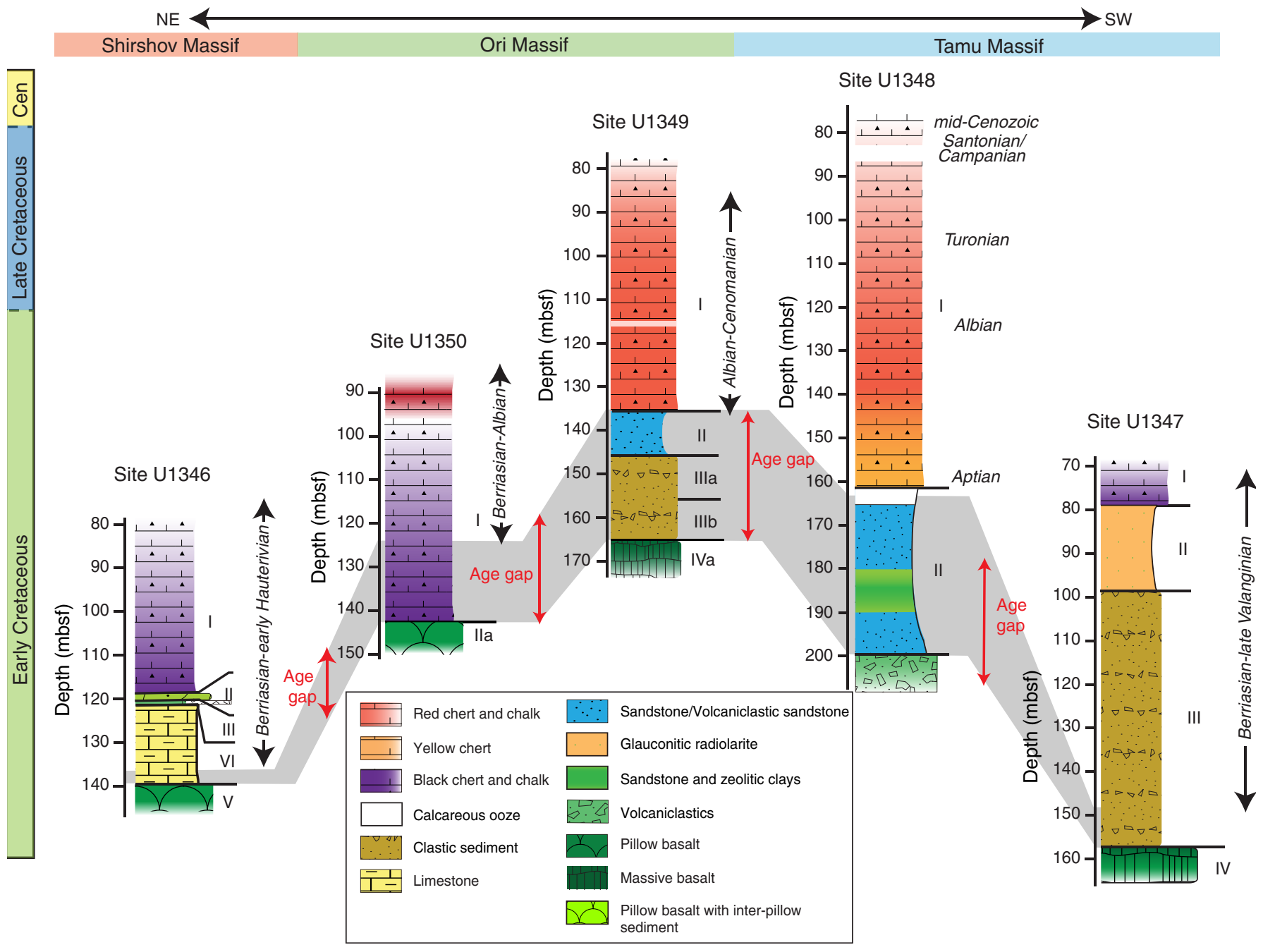


Figure F9. Lithologic summary, Expedition 324.

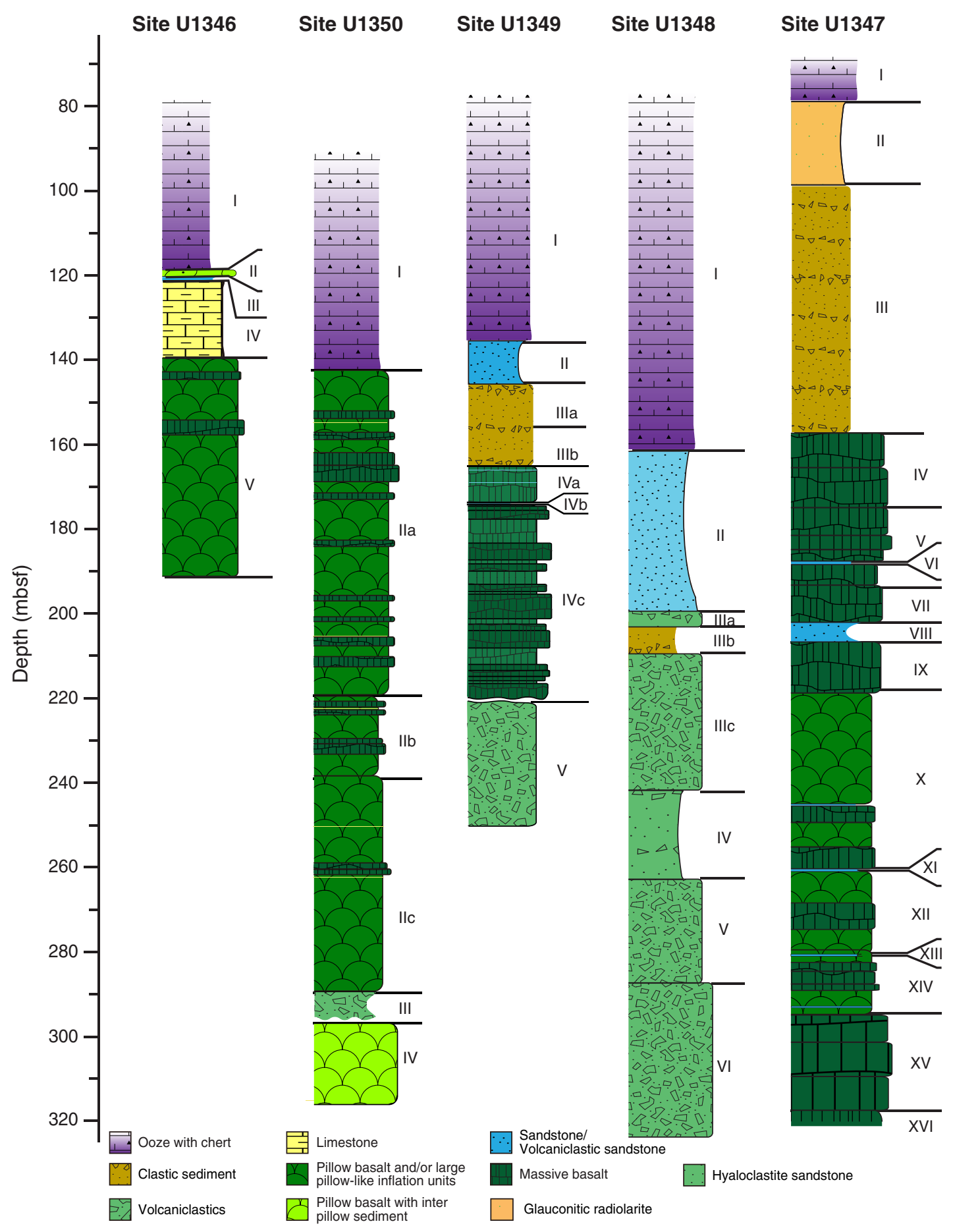


Figure F10. Cross-section of pillow flow unit of amygdaloidal basalt observed at Site U1346 (left; interval 324U1346A-14R-1 [Piece 7, 66-94 cm]) and an idealized sketch of pillow features (right).

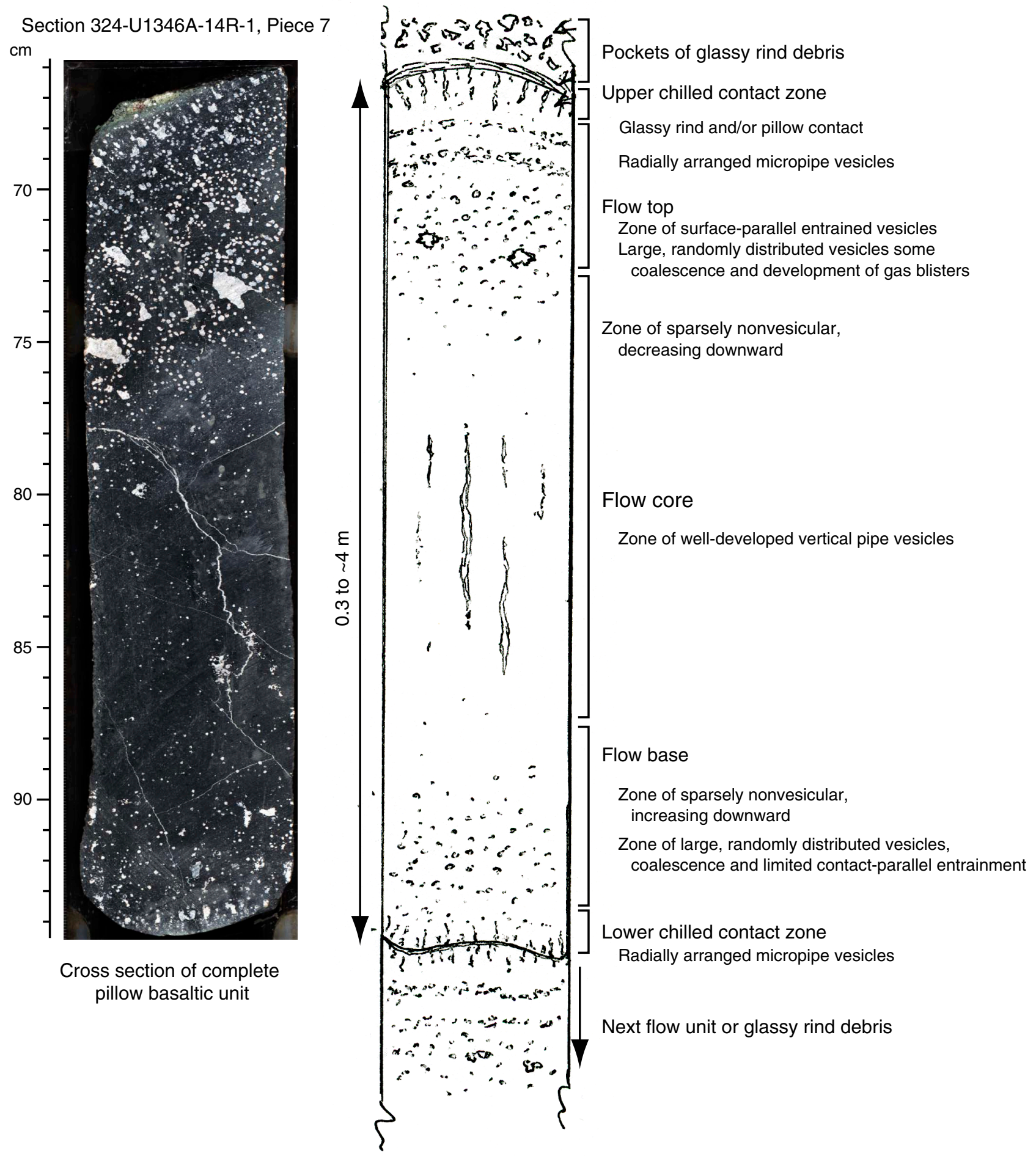


Figure F11. A. Total alkalis vs. silica, with Le Maitre et al.'s (1989) classification of volcanic rock types. Dashed line = Hawaiian tholeiitic and alkalic lava data division (Macdonald and Katsura, 1964; Macdonald, 1968). All data are normalized to $100 \mathrm{wt} \%$ totals. Black arrow $=$ compositional change caused by seawater alteration. B. $\mathrm{TiO}_{2}$ vs. Zr. ODP Leg 191 Site 1179 and Leg 198 Site 1213 data from Mahoney et al. (2005). OJP = Ontong Java Plateau (data of Tejada et al., 1996, 2002; Fitton and Godard, 2004), EPR = East Pacific Rise (data of Sinton et al., 1991; Bach et al., 1994; Mahoney et al., 1994), ESC = Easter Seamount Chain (data of Ray et al., submitted). Nazca Ridge and Easter Seamount Chain together form the hotspot trail of the Easter-Salas hotspot.

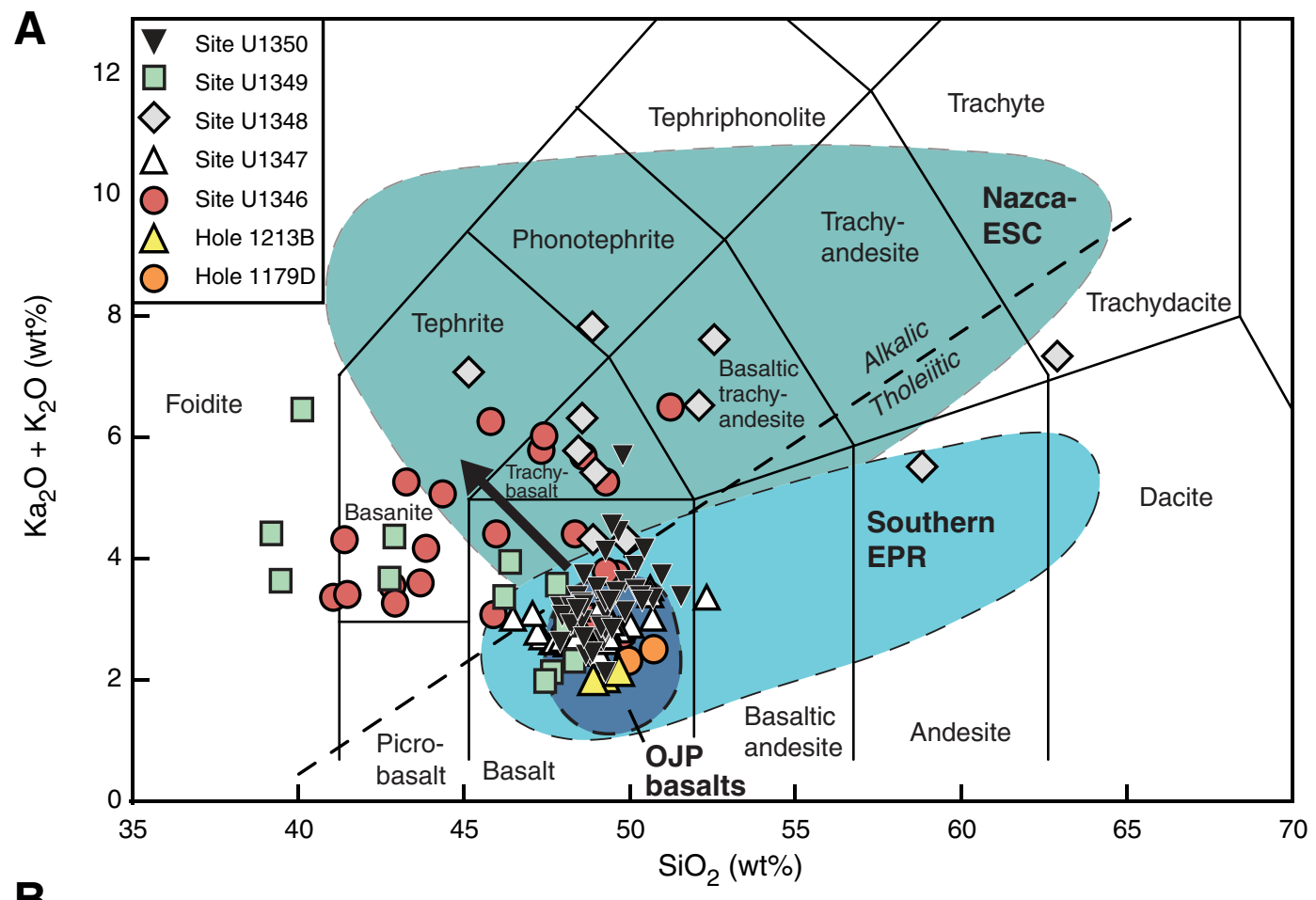

B

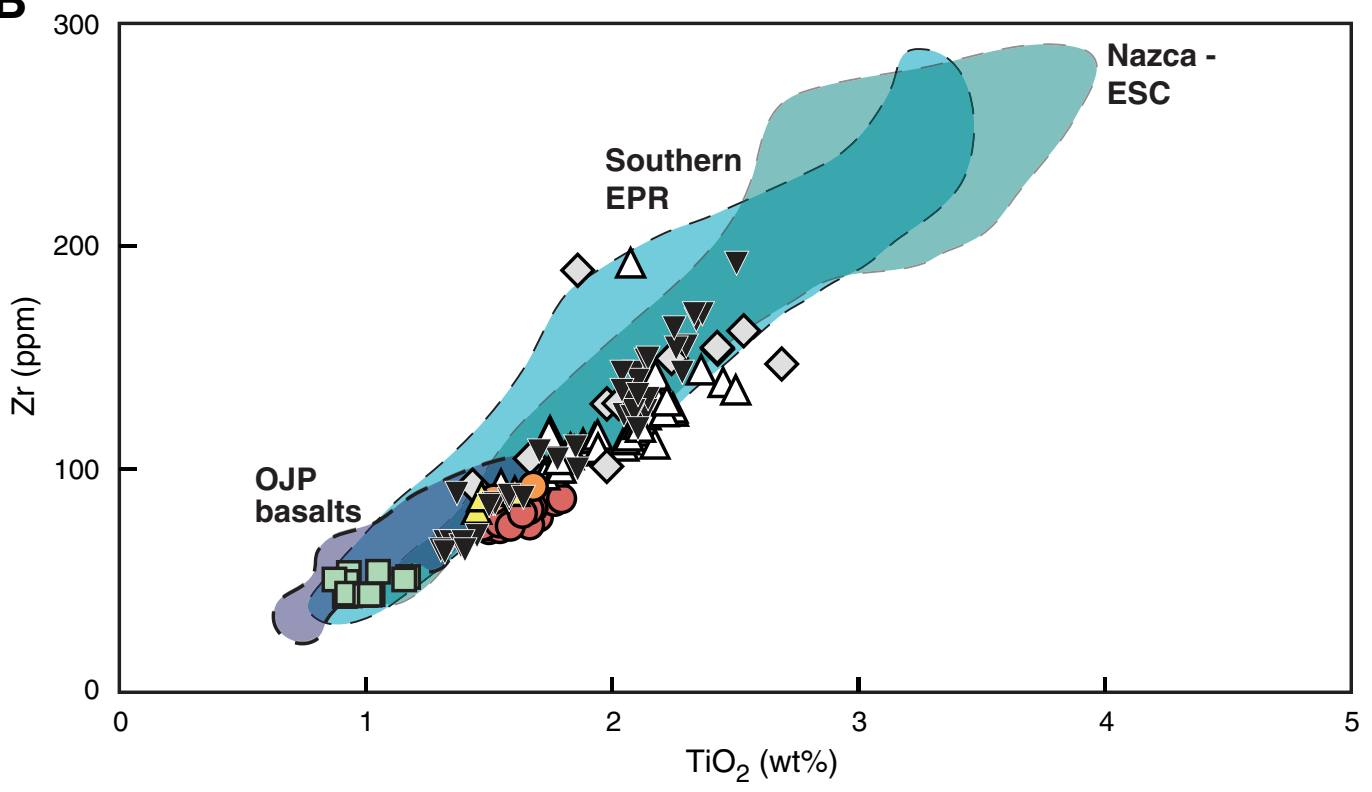


Figure F12. Bathymetry of Tamu Massif and location of Sites U1347 and U1348. Contours and colors indicate bathymetric depths predicted by satellite altimetry (Smith and Sandwell, 1997). Contours shown at $200 \mathrm{~m}$ intervals; dark contours shown for kilometer multiples. Red line $=$ track of Cruise TN037 site survey (Klaus and Sager, 2002), open circles $=$ prior drill sites, blue circle $=$ location of Site 1213.

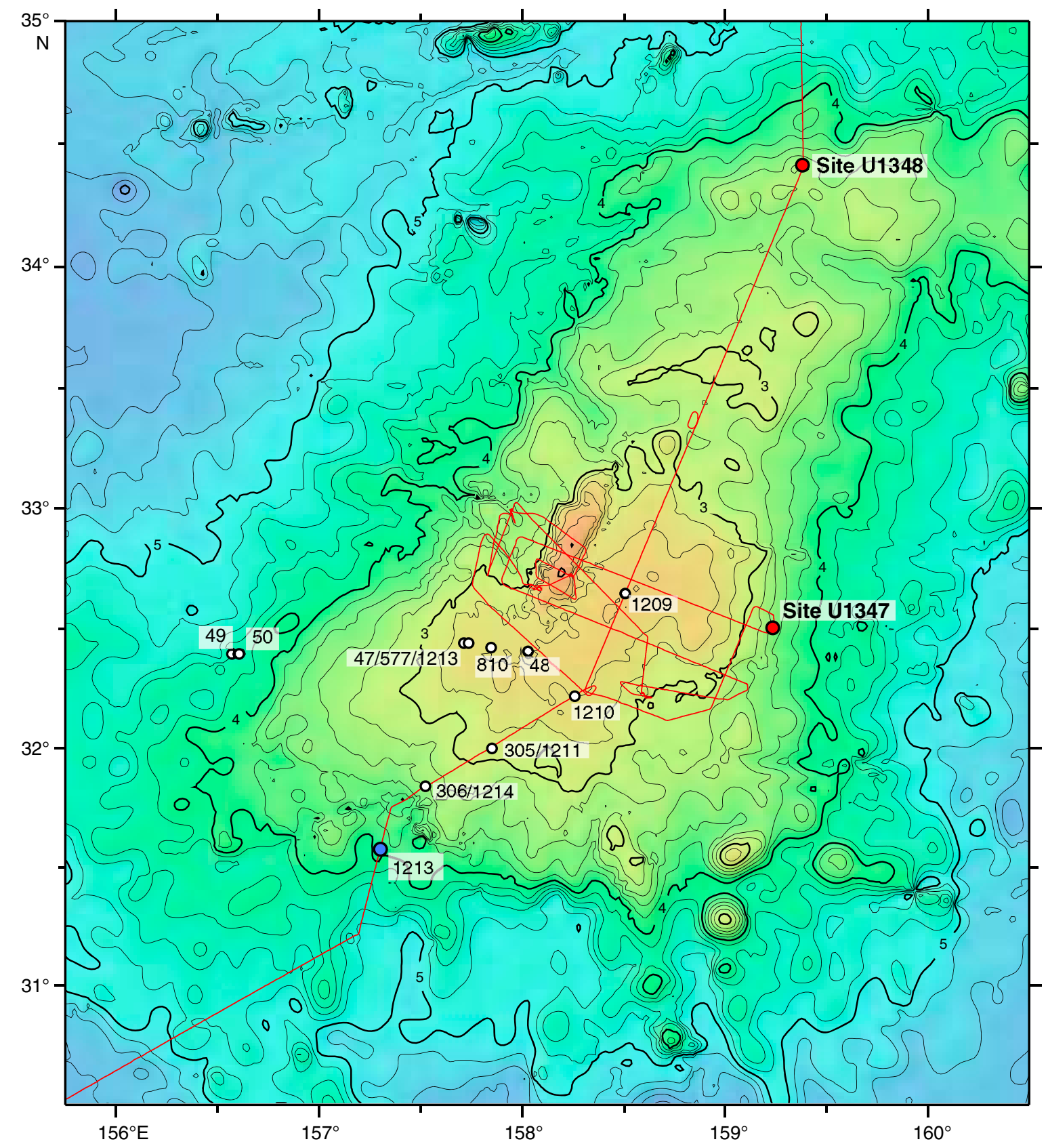


Figure F13. Seismic section and interpretation, Site U1347. See Klaus and Sager (2002). Dashed yellow lines = coherent reflections within igneous basement. UTC $=$ Universal Time Coordinated, $\mathrm{c} / \mathrm{c}=$ course change.

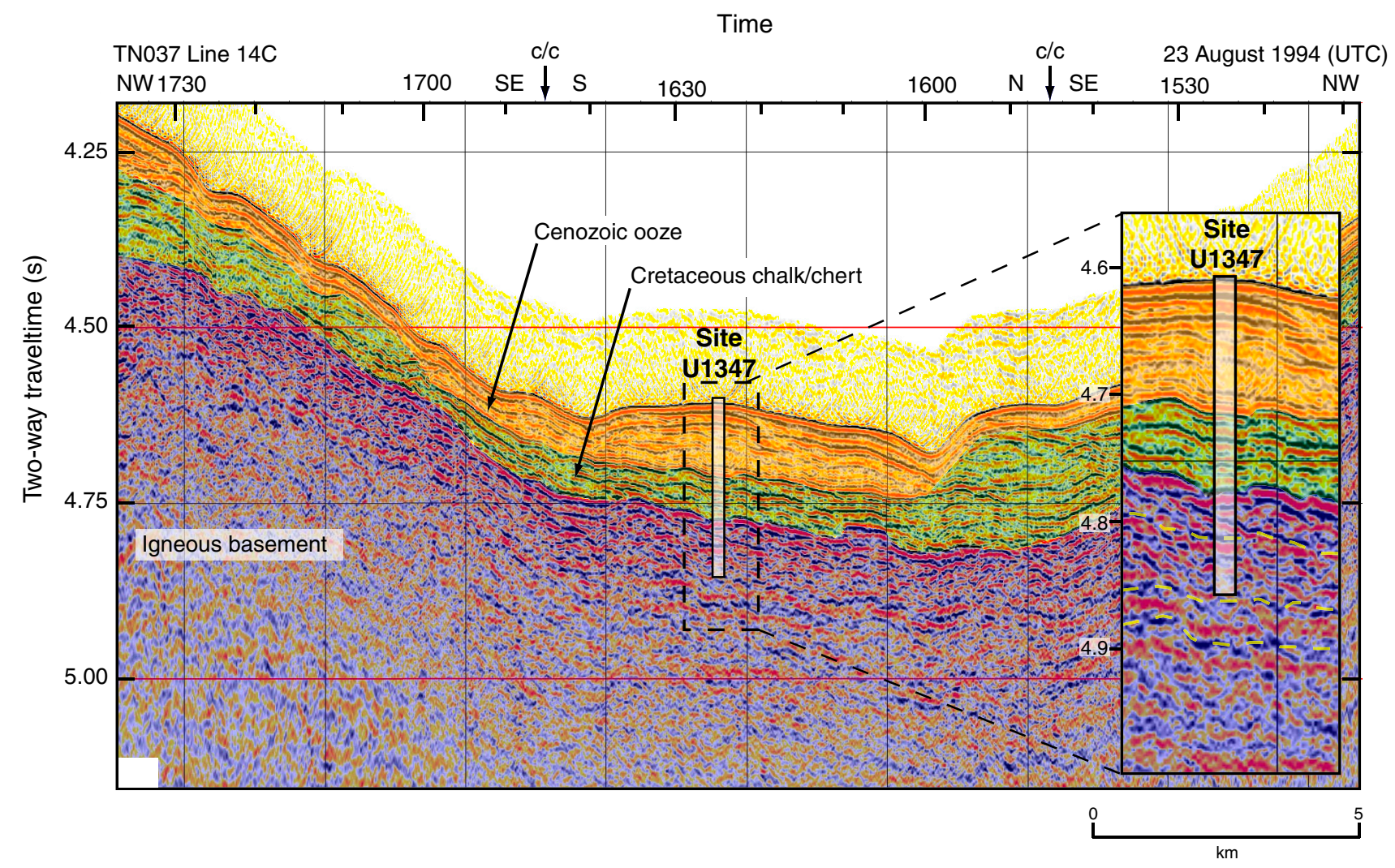


Figure F14. Core section images annotated with volcanological features for a massive submarine basalt flow (Unit V) from Sections 324-U1347A-13R-7 to 15R-1. The lithologic column on the left shows the upper and lower bounds of the sections (red dashed lines). These core sections exhibit primary magmatic features including folded glassy crusts and vesicular zones. Interflow sediment occurs between the massive flows in Section 324-U1347A-15R-1 and appears to be $\sim 5 \mathrm{~m}$ thick in downhole logging measurements.

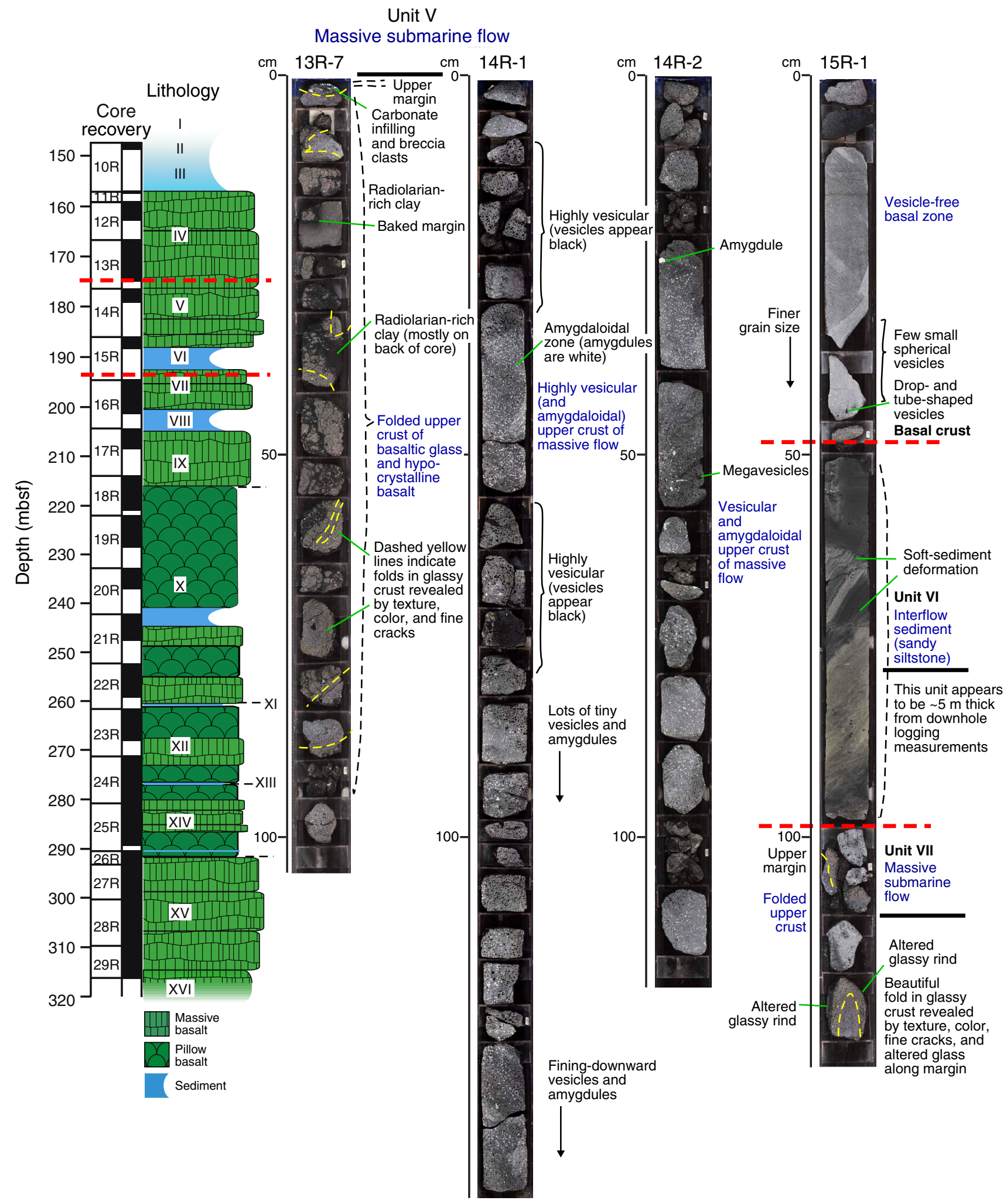


Figure F15. Core images annotated with volcanological features for a section of the lower pillow basalts (Unit XIV) and upper part of a massive basalt flow (Unit XV) from Sections 324-U1347A-25R-3 to 26R-2 (between red dashed lines in column at left). Top and bottom of pillow lobes are indicated with red text and glassy chilled margins are indicated with dashed green lines.

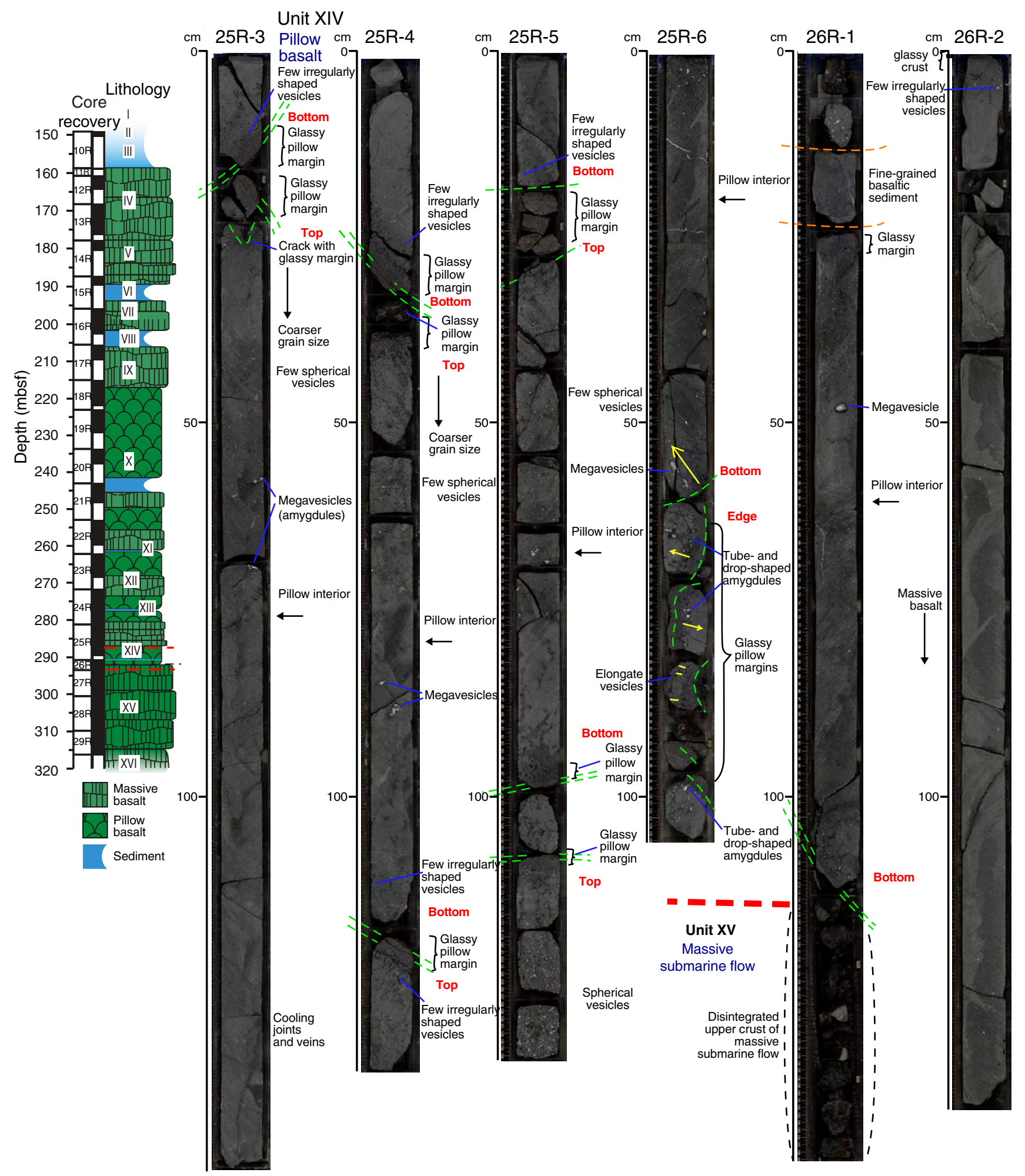


Figure F16. Seismic section and interpretation, Site U1348. See Klaus and Sager (2002). UTC = Universal Time Coordinated.

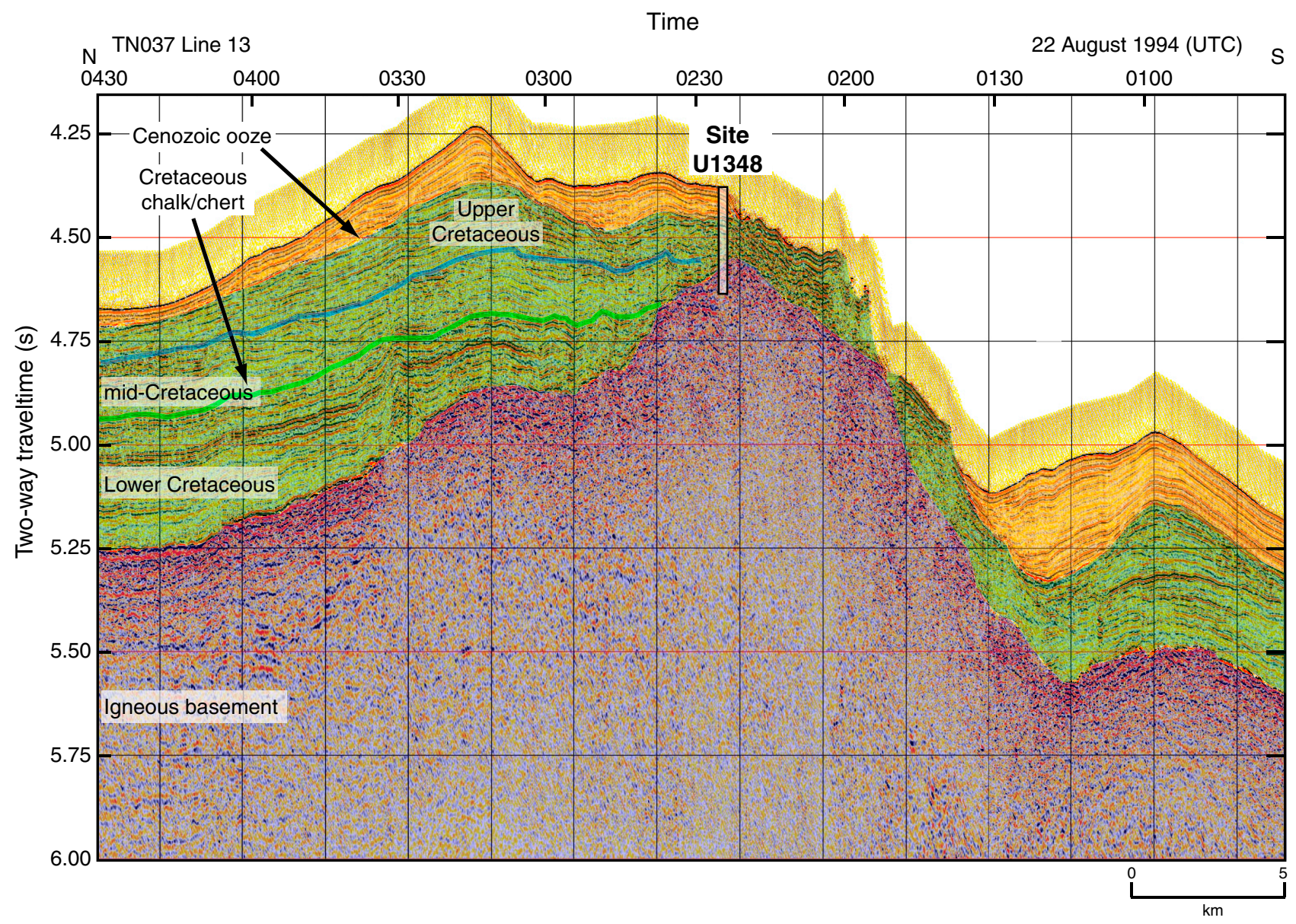


Figure F17. (A) Core section image, (B) thin section scan, and photomicrographs (plane-polarized transmitted light) of sparsely vesicular vitric tuff in Section 324-U1348A-18R-1, top of Unit III, with (C) glass shards and bubble wall fragments, (D) subrounded vesicular basalt clasts, and (E) fine hyaloclastite matrix. Thin section scan location of B is indicated by the red box in A. Width of field of view of photomicrographs is $\sim 15 \mathrm{~mm}$ $(1.25 \times)$ in panels $\mathrm{C}, \mathrm{D}$, and $\mathrm{E}$. Arrows = orientation in core.
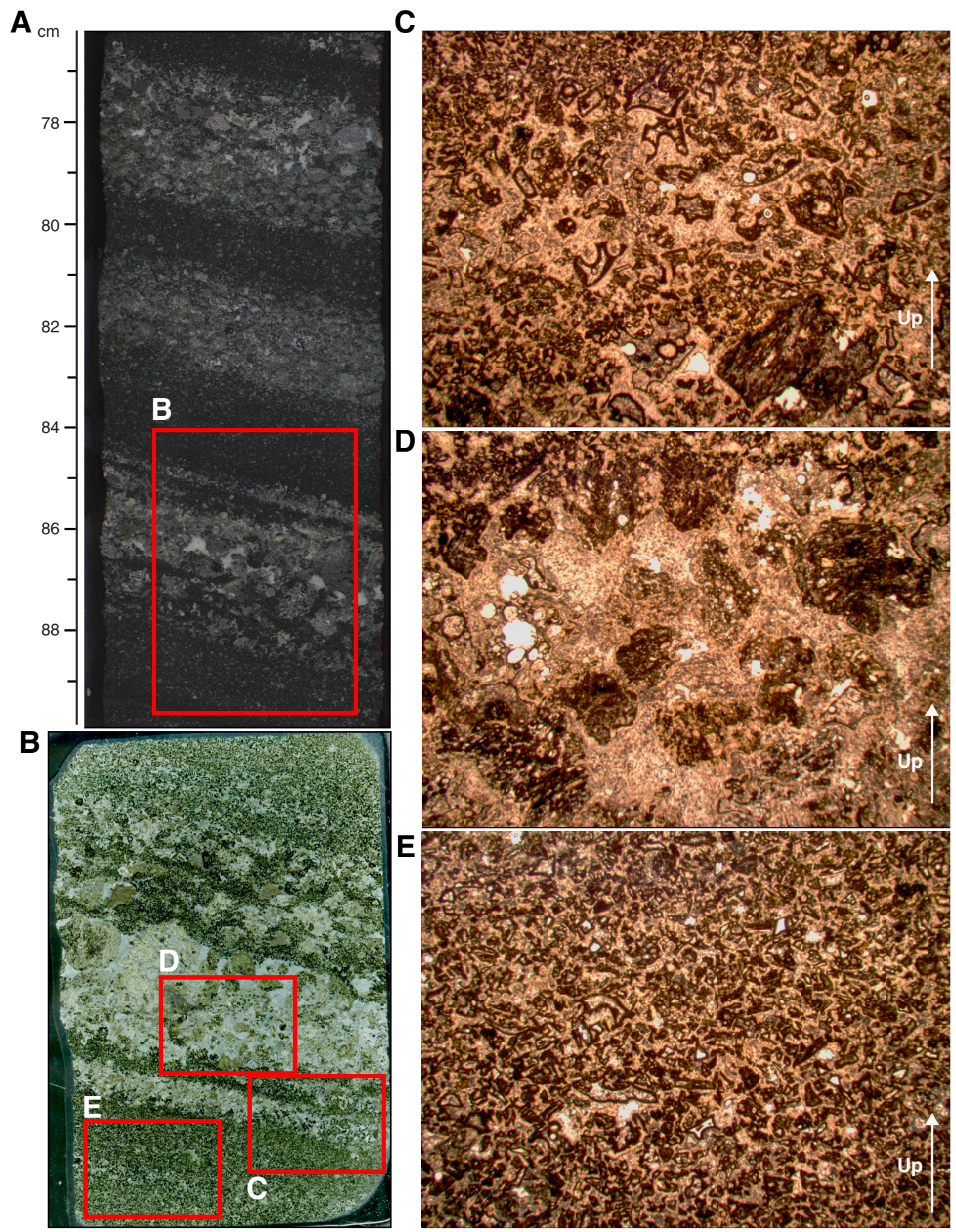
Figure F18. Bathymetry of Ori Massif and location of Sites U1349 and U1350. Contours and colors indicate bathymetric depths predicted by satellite altimetry (Smith and Sandwell, 1997). Contours shown at $200 \mathrm{~m}$ intervals; dark contours shown for kilometer multiples. Red line $=$ track of Cruise TN037 site survey (Klaus and Sager, 2002), open circle = location of ODP Leg 198 Site 1208.

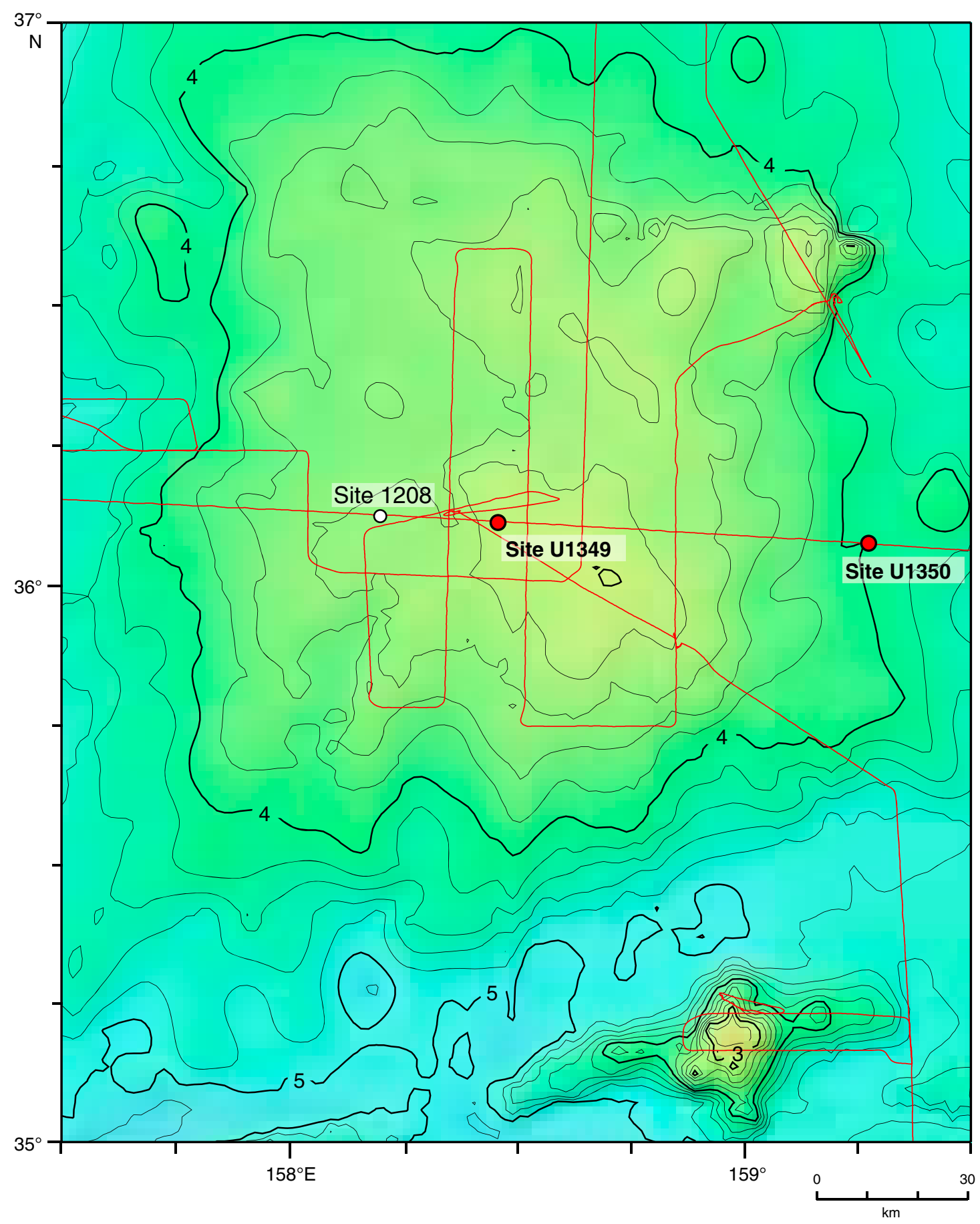


Figure F19. Seismic section and interpretation, Site U1349. See Klaus and Sager (2002).

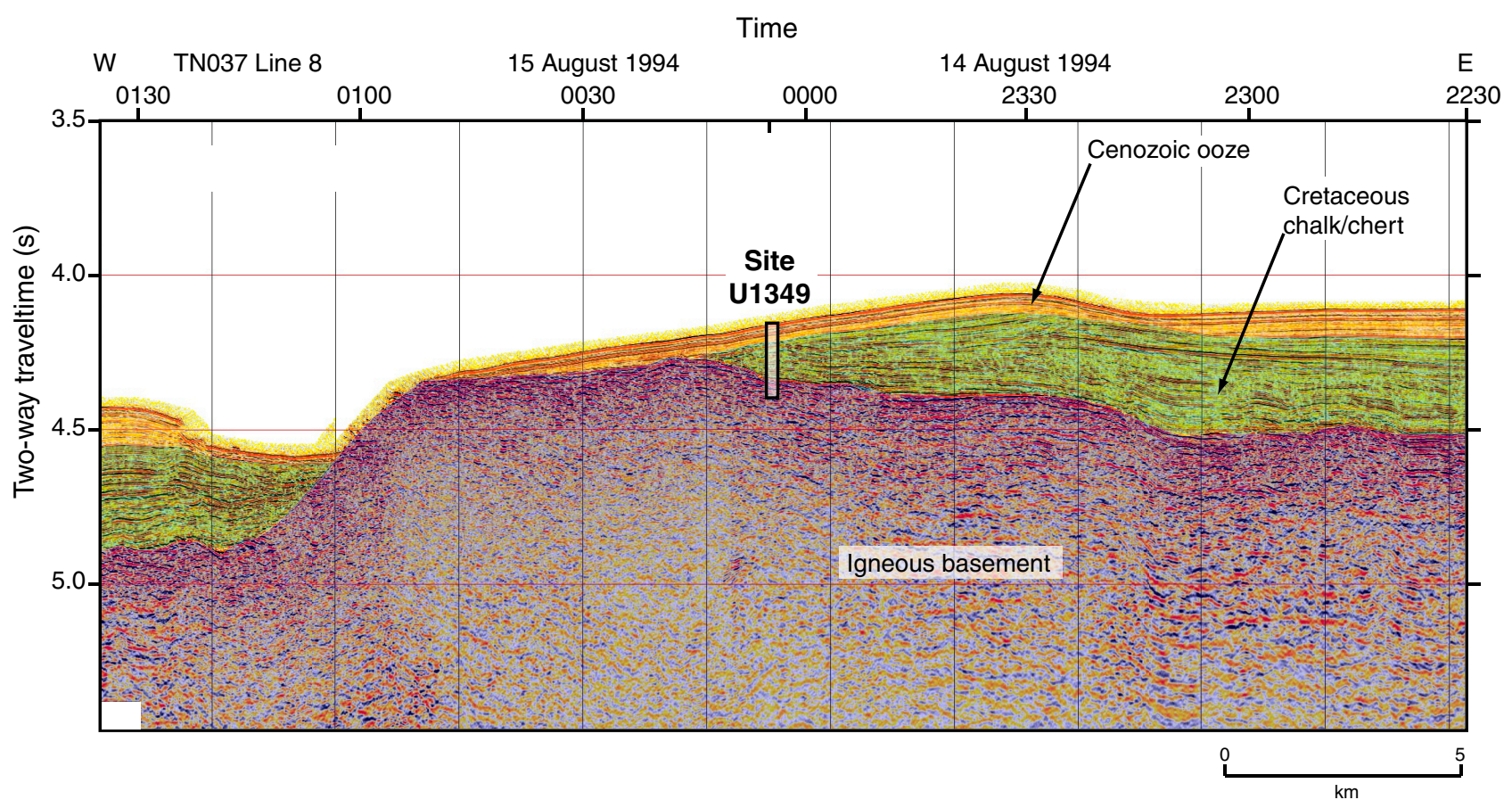


Figure F20. Core section images of Sections (A) 324-U1349-11R-3, (B) 11R-5, (C) 11R-4, (D) thin section scan, and (E-G) photomicrographs (plane-polarized transmitted light) of lava mixing features in Core 324-U1349A$11 \mathrm{R}$, top of Unit IV. Thin section scan location of $\mathrm{D}$ is indicated by the red box in B. Red box in D indicates photomicrograph location. $\mathrm{G}$ is a close-up view of the area indicated by the red box in E. Field of view for D is $36 \mathrm{~cm} \times 54 \mathrm{~cm}$. Width of field of view of $\mathrm{F}$ and $\mathrm{G}$ is $\sim 6 \mathrm{~mm}(2.5 \times)$ and $\mathrm{E}$ is $15 \mathrm{~mm}(1.25 \times)$.

A
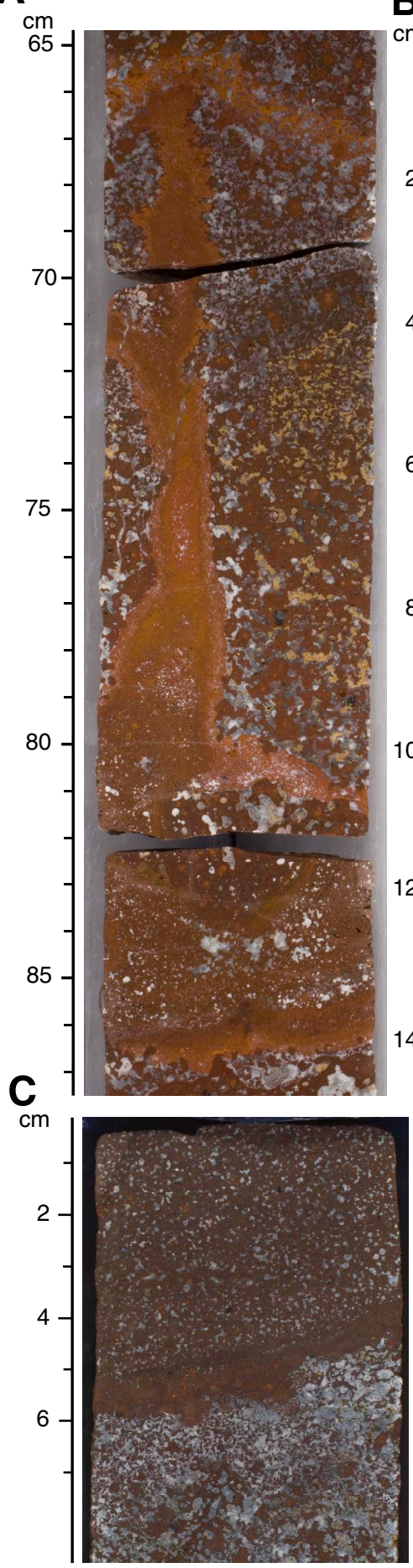

B

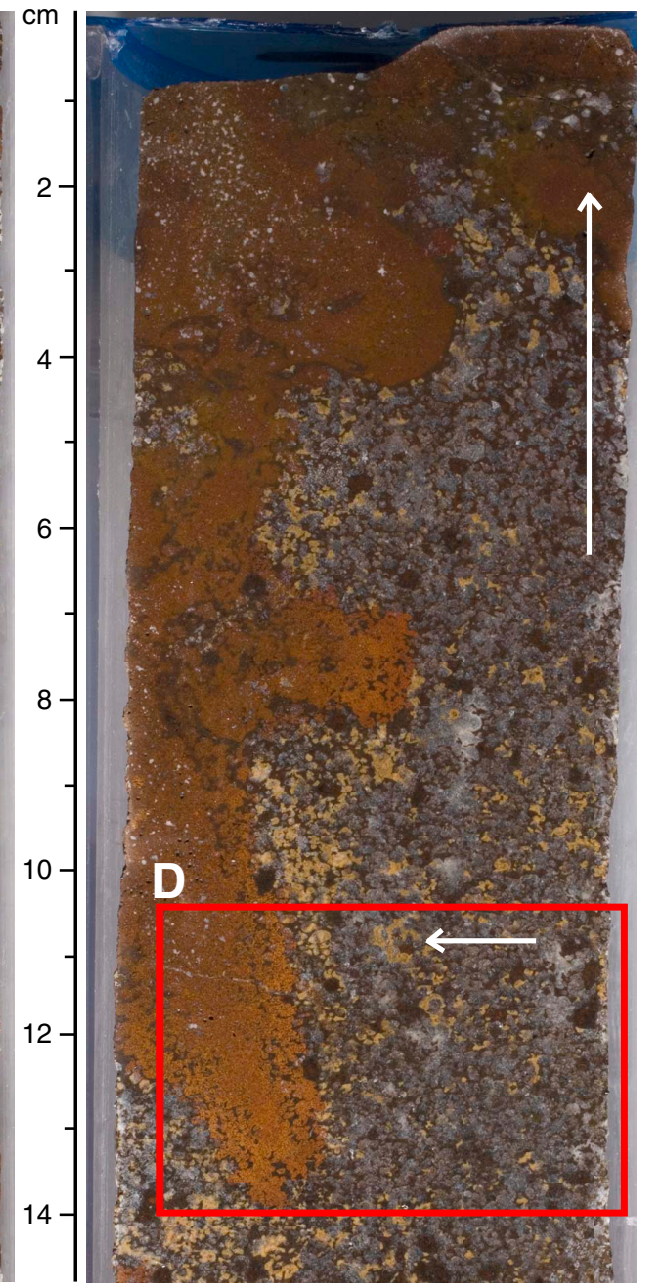

$\mathbf{E}$

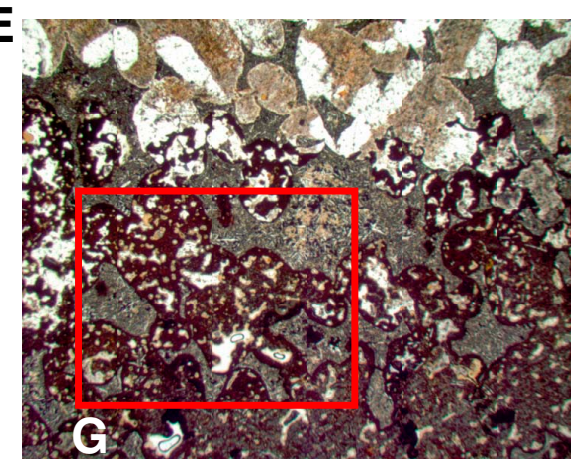

D
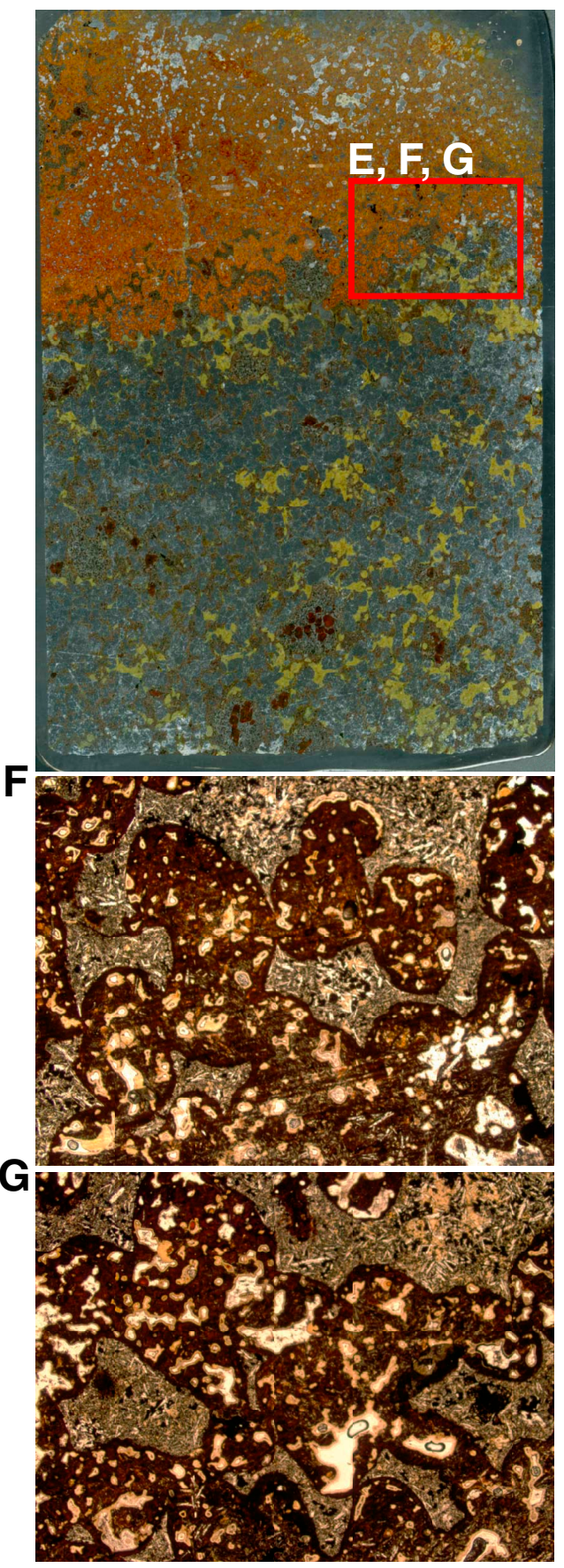
Figure F21. Seismic section and interpretation, Site U1350. See Klaus and Sager (2002).

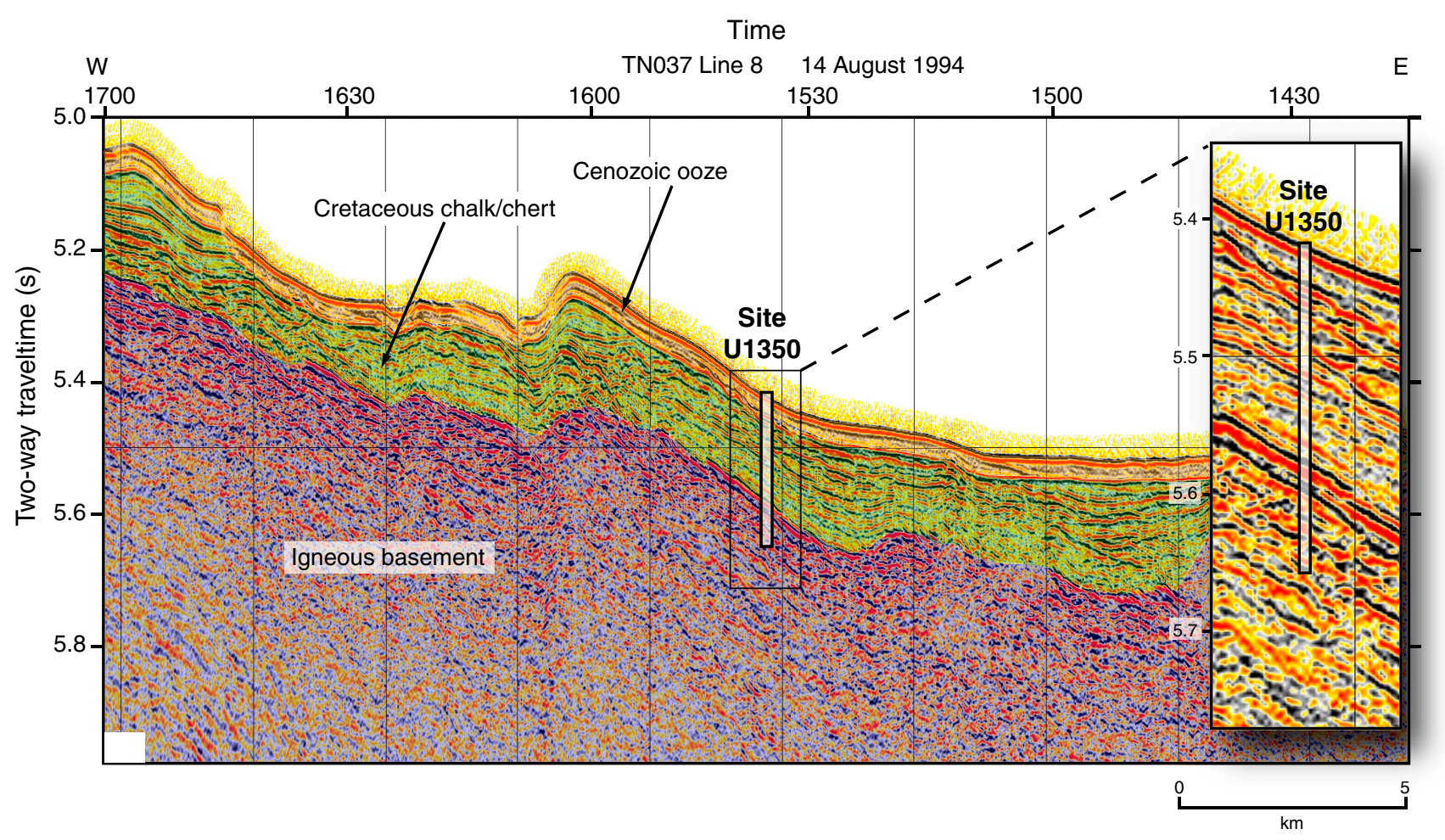


Figure F22. Core section images annotated with volcanological features for pillow basalts from Unit IV (Sections 324-U1350-26R-1 through 26R-8). Yellow dashed lines = pillow margins or interpillow crusts. These core sections exhibit interior pillow cracks, concentric vesicles in pillow margins, and sediment incorporated into pillow interiors.

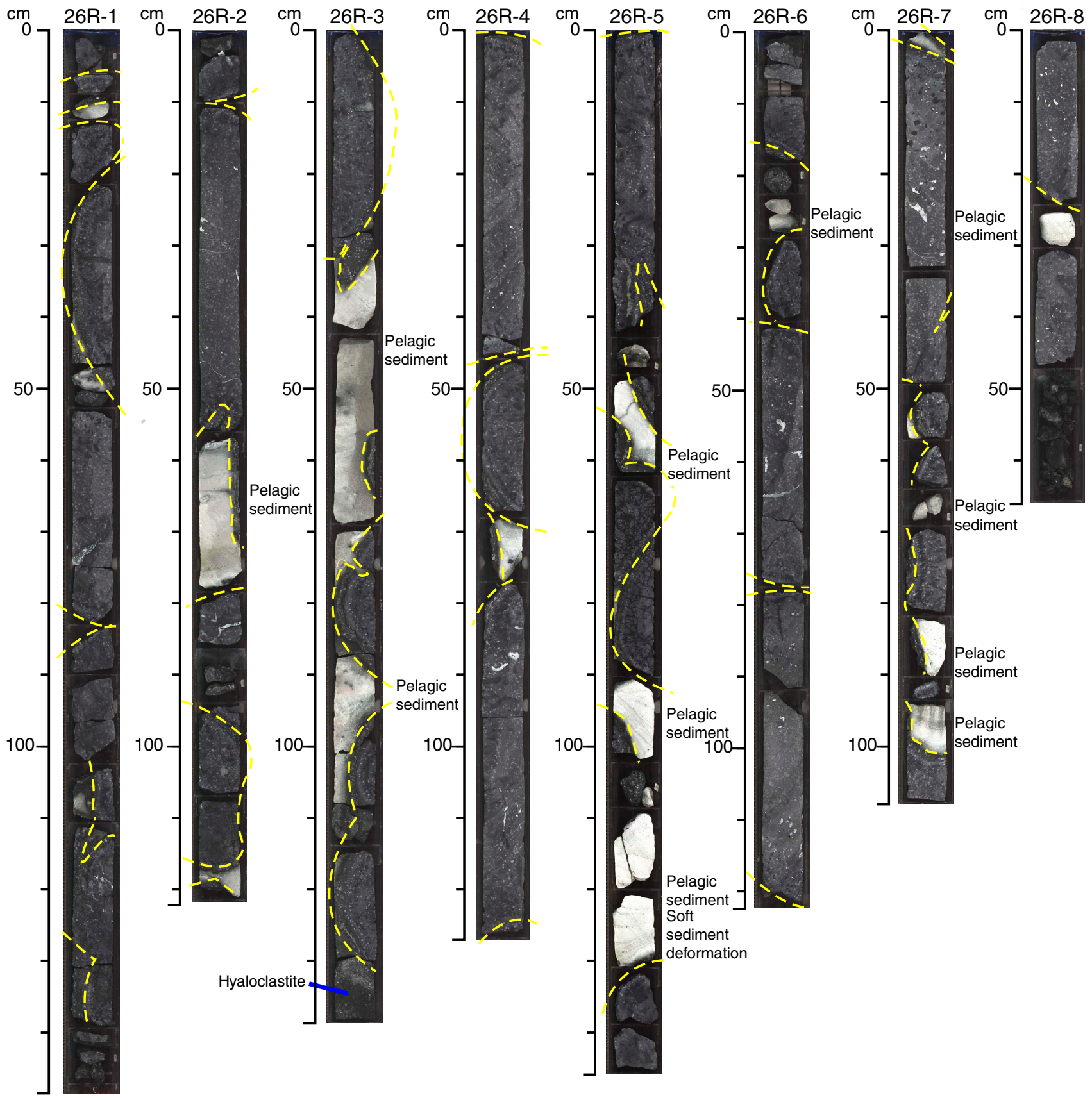


Figure F23. Examples of massive flows, Hole U1350A. A. Lithologic column. Red dashed lines $=$ upper and lower bounds of sections. B. Core images of Sections 324-U1350A-9R-6, 10R-1, 10R-2, and 11R-2. C-E. Photomicrographs of areas indicated by yellow boxes in B. C, D. Thin Section 274 (Sample 324-U1350A-10R-2, 33$35 \mathrm{~cm}$ ). Height of view of C is $12 \mathrm{~mm}$; height of view of D is $6 \mathrm{~mm}$. E. Thin Section 277 (Sample 324-U1350A11R-2, 80-83 cm). Height of view is $6 \mathrm{~mm}$. Plane-polarized transmitted light.

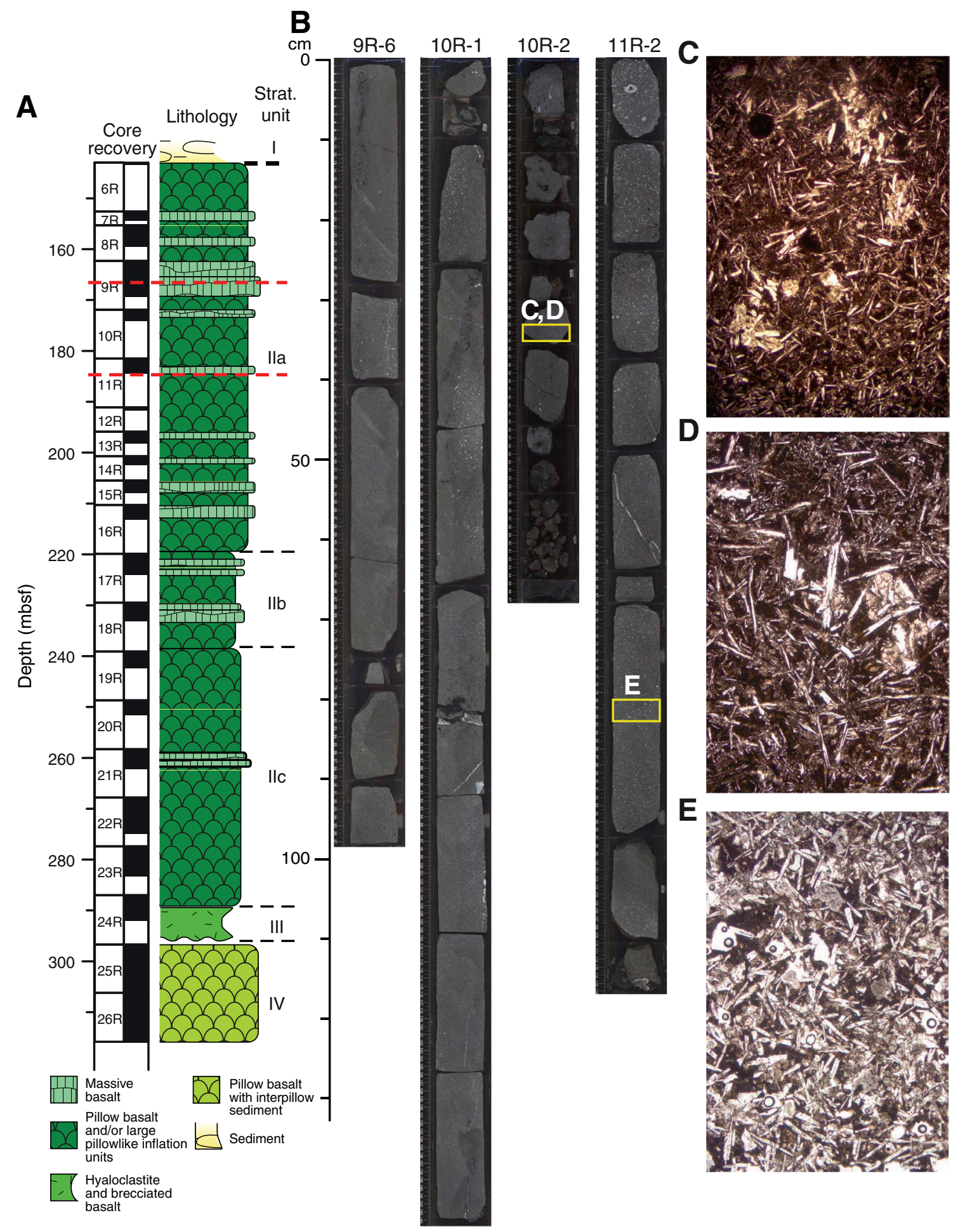


Figure F24. Examples of pillow lavas, Hole U1350A. A. Lithologic column. B. Images of Sections 324-U1350A22R-2 through 22R-5 (location shown as red dashed lines in A). Yellow boxes on core images show locations of thin sections. C-E. Thin section scan (C) and thin section photomicrographs (D, E) of aphyric pillow basalt from Subunit IIc showing small spherical vesicles in the upper parts of pillows, characteristic jointing patterns, tube- and drop-shape vesicles inside chilled margins, and thin subhorizontal glassy rinds (plane-polarized transmitted light); (C) Thin Section 307; Sample 324-U1350A-22R-5, 81-87 cm; (D) close-up of area in yellow box in C (length of view = $12 \mathrm{~mm}$ ); (E) Thin Section 306; Sample 324-U1350A-22R-3, 117-119 cm (length of view $=6 \mathrm{~mm})$.

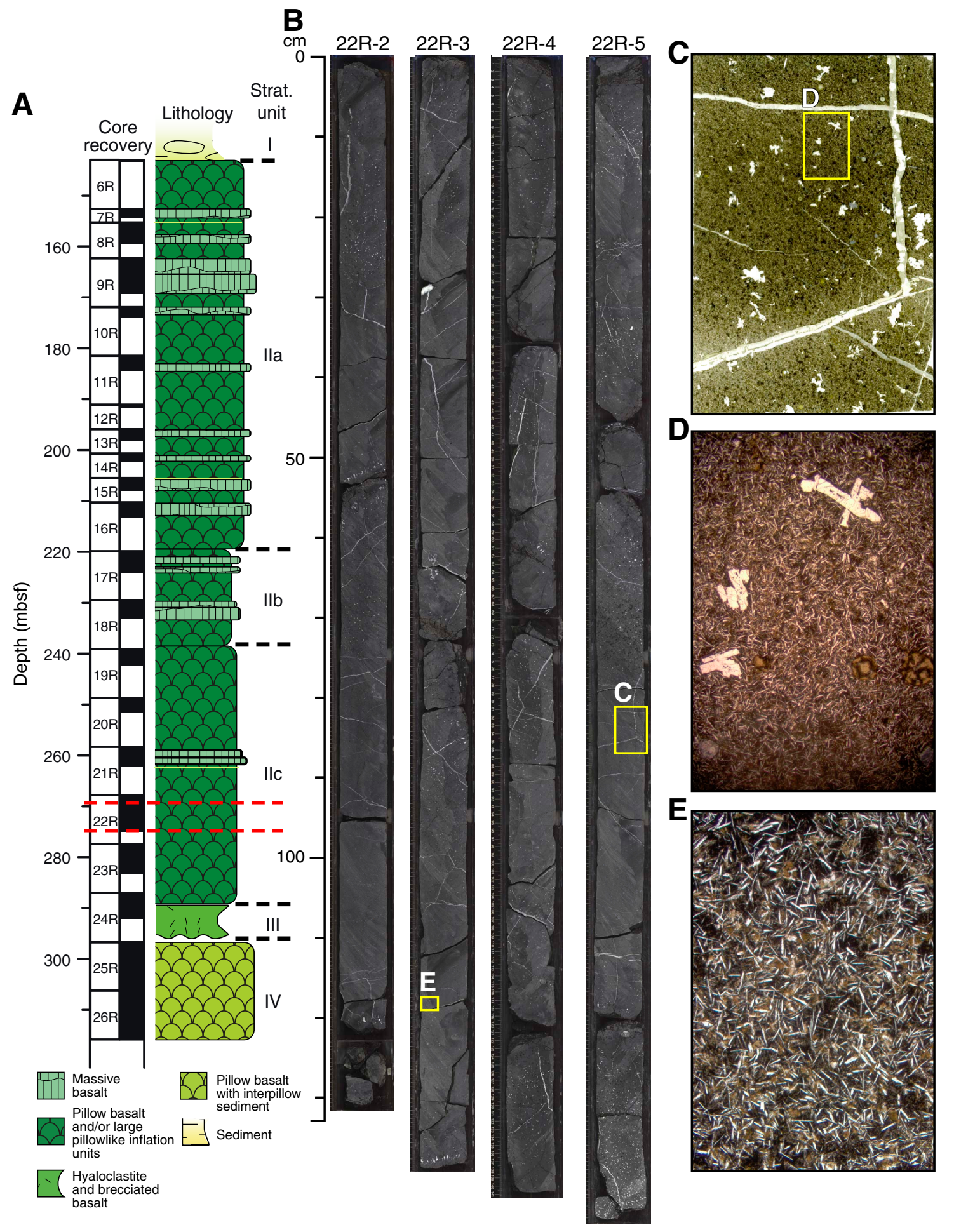


Figure F25. Examples of pillow breccia/hyaloclastite, Hole U1350A. A. Lithologic column. B. Image of Section 324-U1350A-24R-3 showing pillow breccia/hyaloclastite from Unit III (location shown as red dashed lines in A), which exhibits pillow fragments and several globular clasts with chilled margins in a matrix of hyaloclastite. Yellow boxes on core image indicate the locations thin sections. C. Sample 324-U1350A-24R-3, 105-120 cm. D. Sample 324-U1350A-24R-3, 90-105 cm. E. Sample 324-U1350A-24R-3, 49-67 cm.

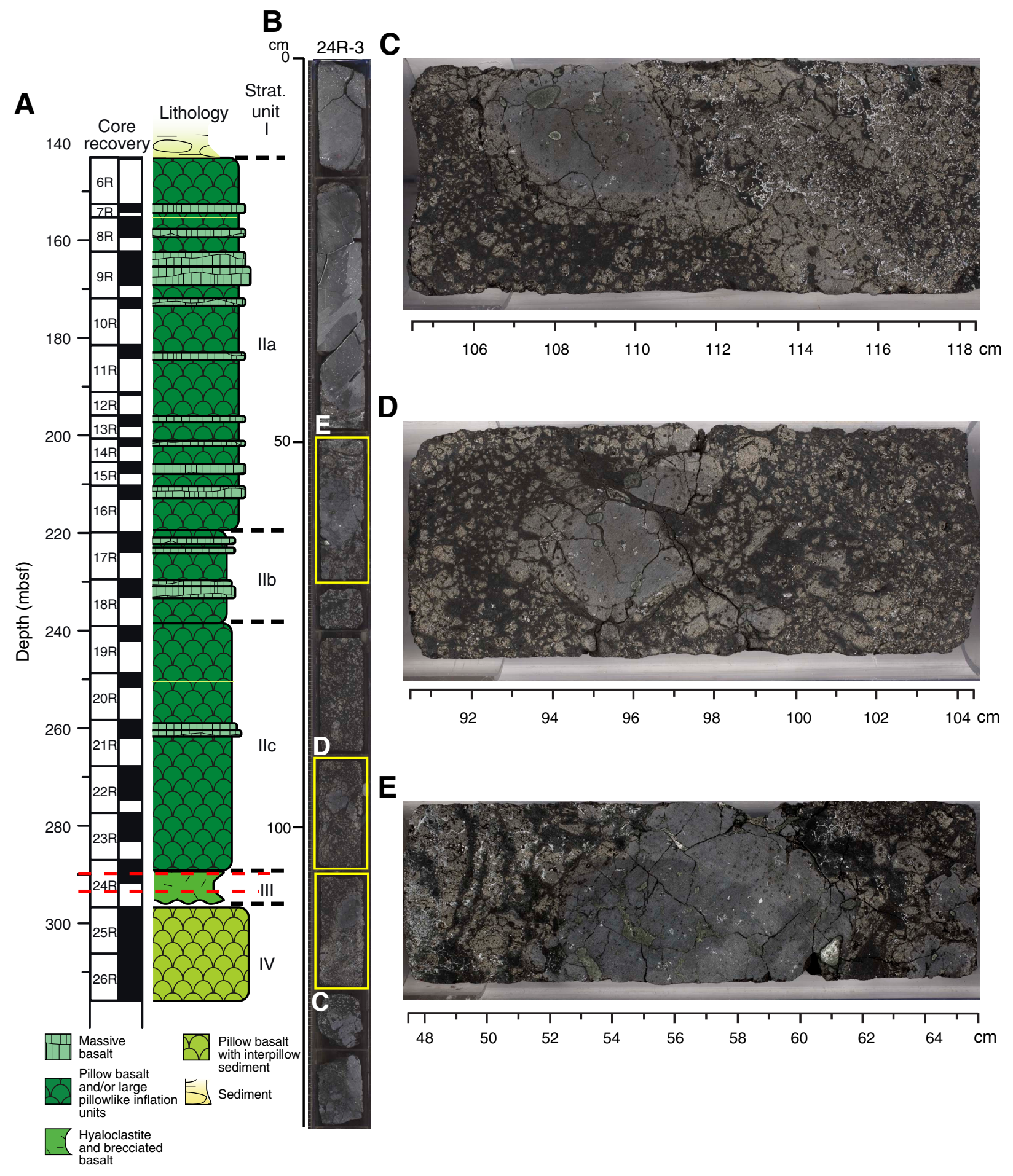


Figure F26. Subsidence curves, Expedition 324. A. Site U1346 (Shirshov Massif summit). B. Site U1349 (Ori Massif summit). C. Site U1350 (Ori Massif flank). D. Site U1347 (Tamu Massif flank). Colored curves = extrapolated site depth at the time of eruptions, calculated by backtracking from the present depth (corrected for sediment loading; Crough, 1983). PS = Parsons and Sclater (1977) model, SS = Stein and Stein (1994) model. Paleodepth estimates from backtracking are compared with paleodepth indicators from Expedition 324 cores. Black curves $=$ normal mid-ocean ridges, red arrow = difference between normal ridge and observed paleodepth, taken as the amount of uplift caused by volcano construction. Magnetic lineation ages are from Nakanishi et al. (1999) and Gradstein et al. (2004).
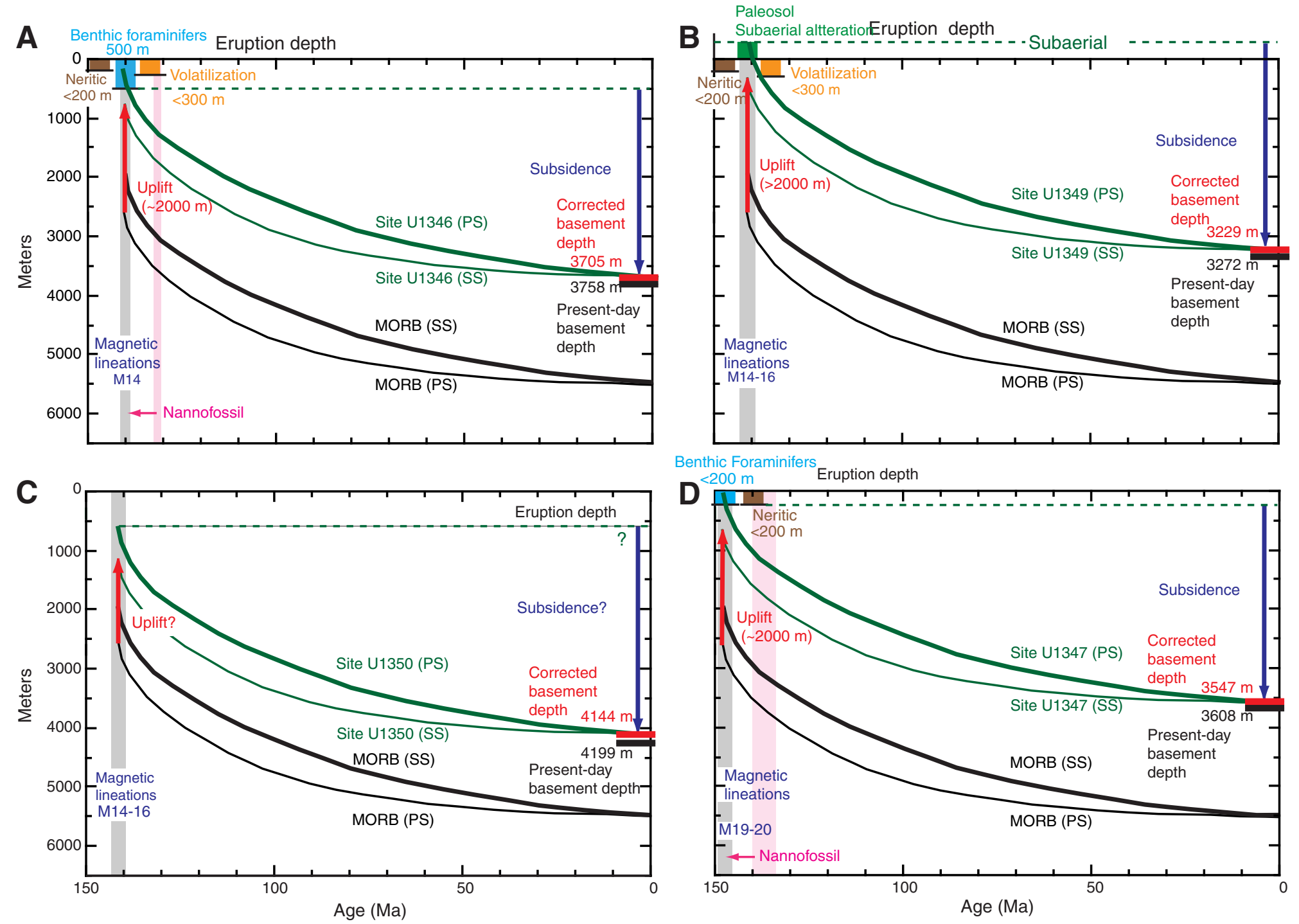
Figure F27. Paleomagnetic inclinations measured from discrete basalt samples plotted versus depth, Sites U1346, U1347, U1349, and U1350. AF = alternating-field demagnetization, TH = thermal demagnetization.
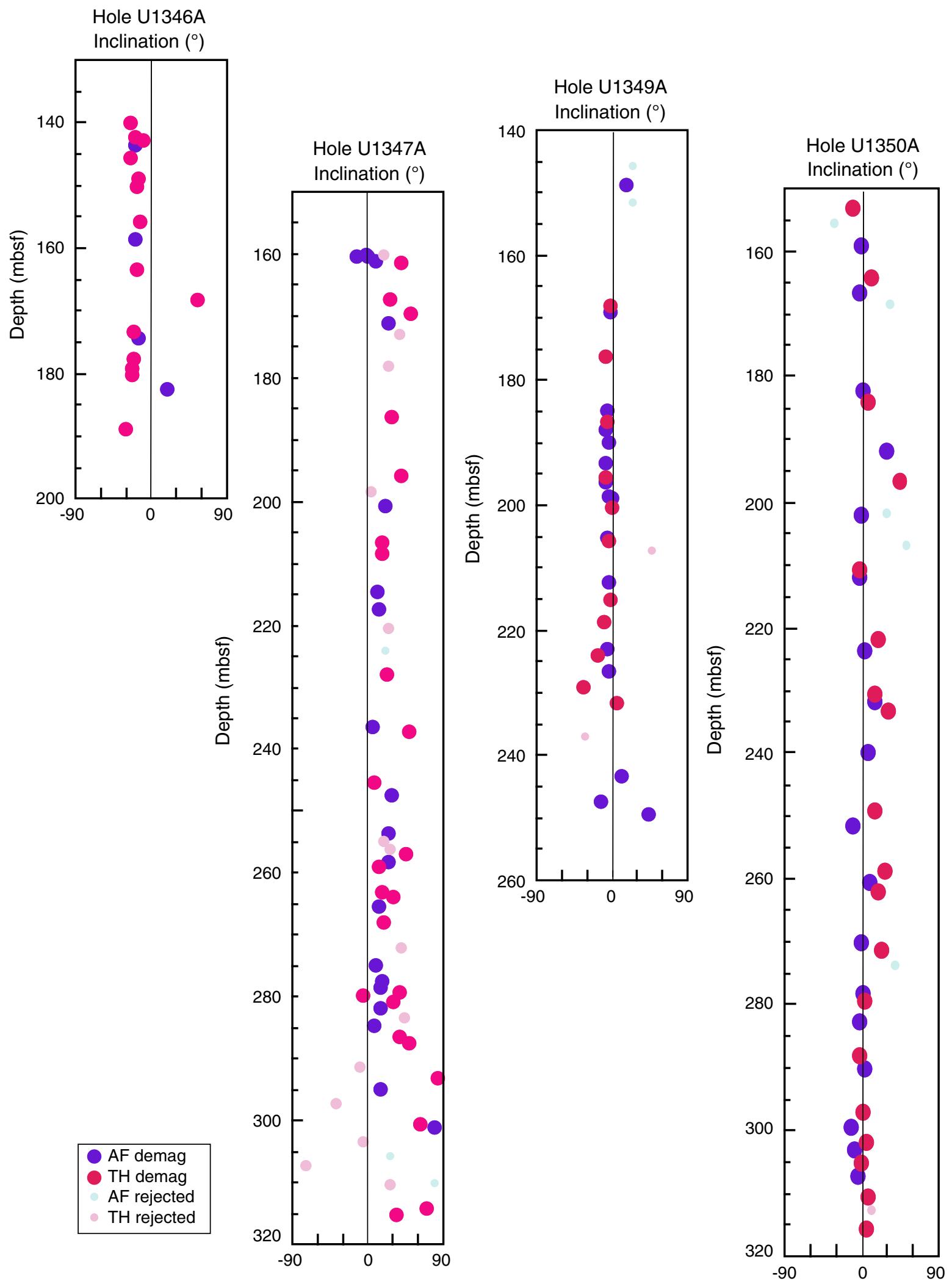
Figure F28. Summary of total NGR counts measured from core sections, Expedition 324. All plots shown at same scale for comparison. Dashed line $=$ contact between sediments and igneous basement.
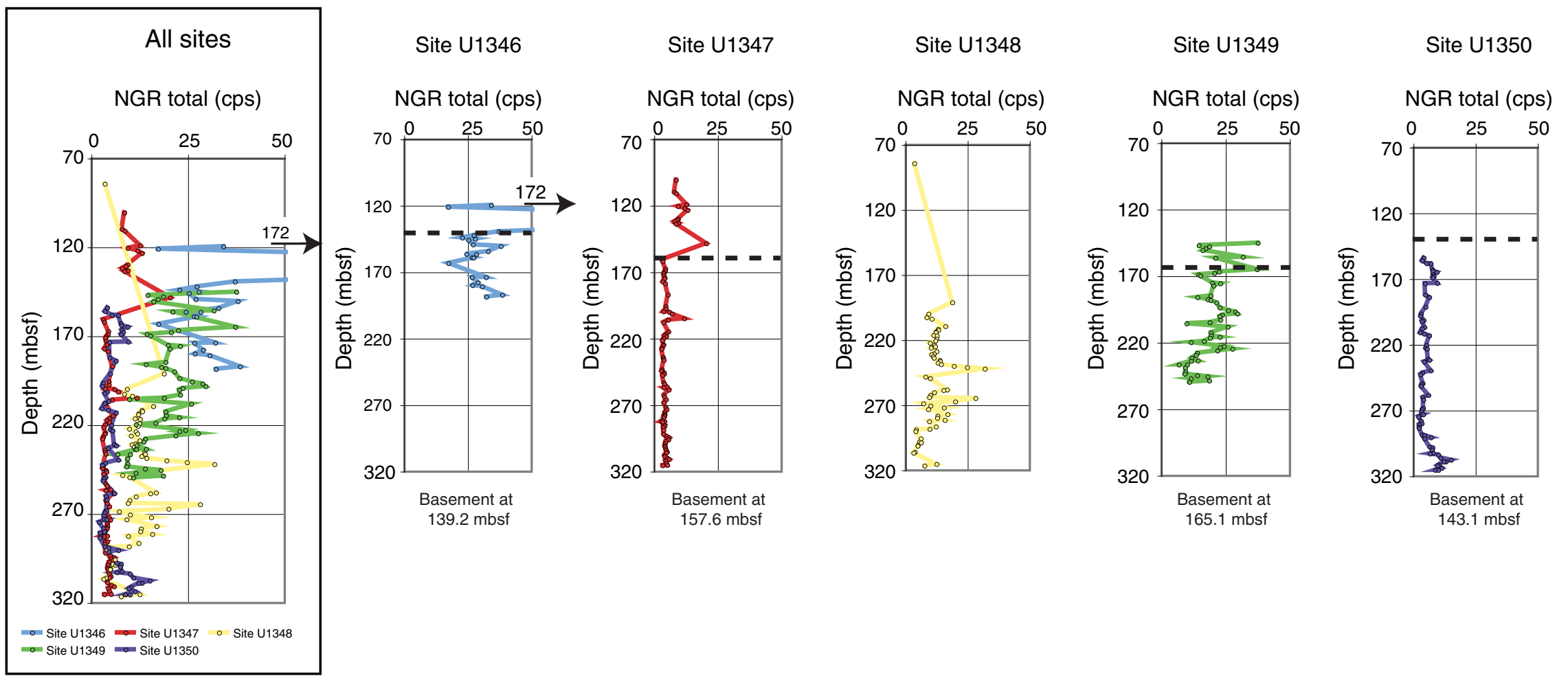
Figure F29. Summary of magnetic susceptibility measured from core sections, Expedition 324. All plots shown at same scale for comparison. As a result, low susceptibility units are not visible. Dashed line = contact between sediments and igneous basement.
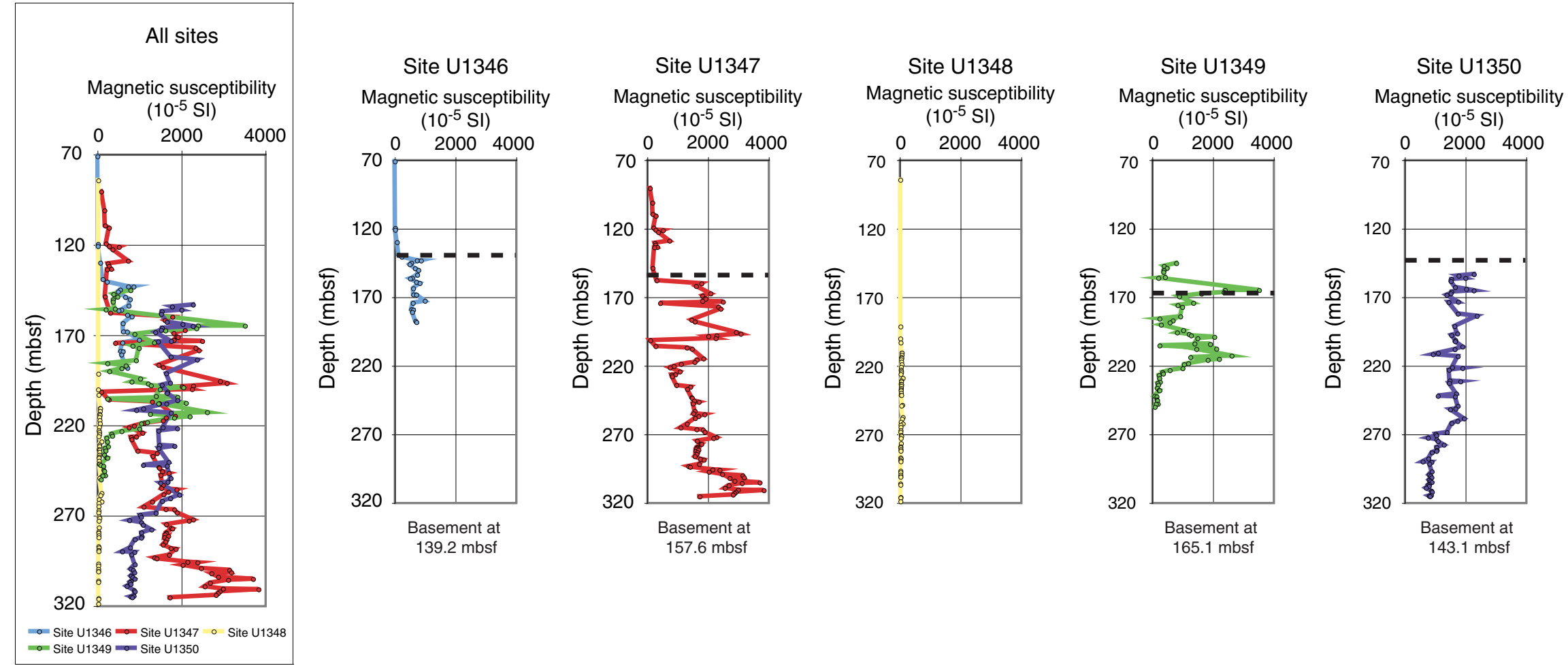
Figure F30. Summary of GRA bulk density measured from core sections, Expedition 324. All plots shown at same scale for comparison. As a result, low GRA units are difficult to see. Dashed line = contact between sediments and igneous basement.
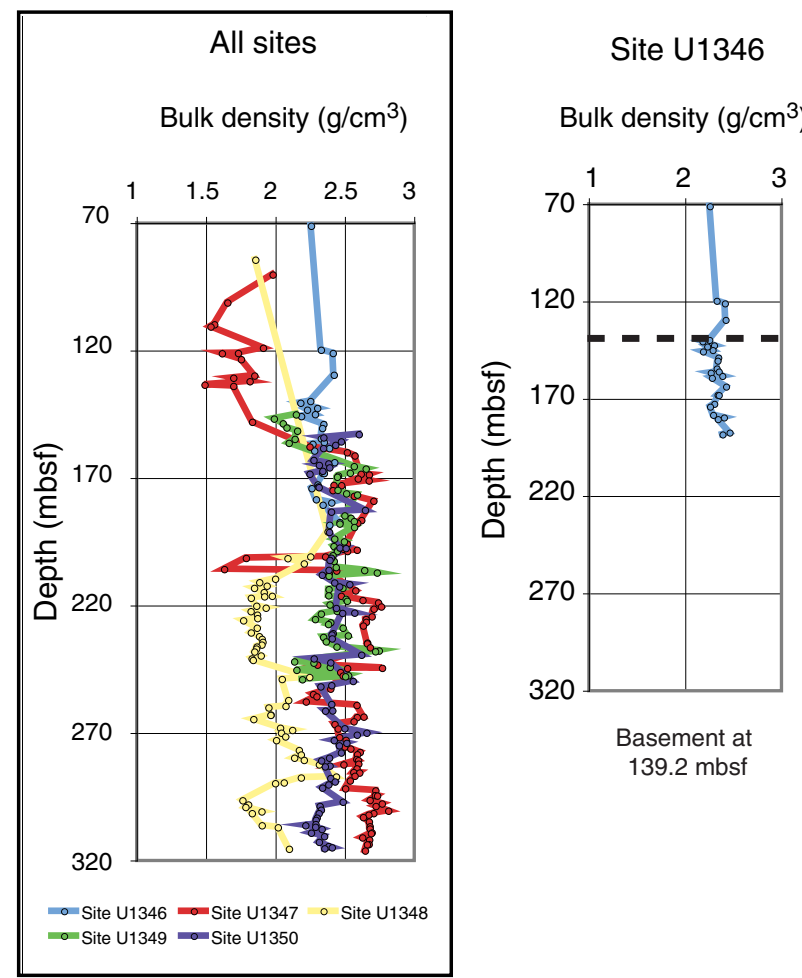

Site U1347

Bulk density $\left(\mathrm{g} / \mathrm{cm}^{3}\right)$

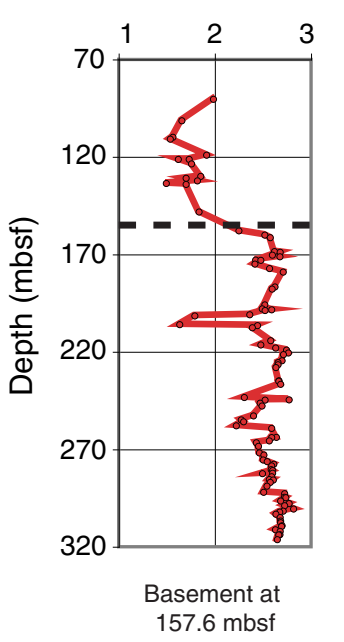

Site U1349

Bulk density $\left(\mathrm{g} / \mathrm{cm}^{3}\right)$

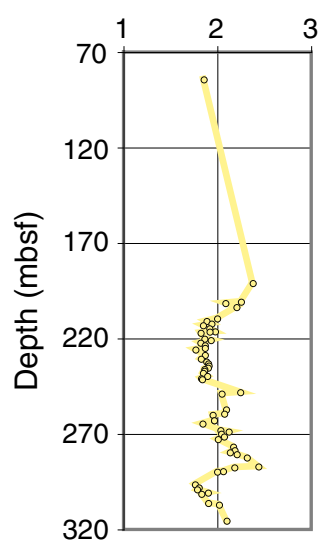

320

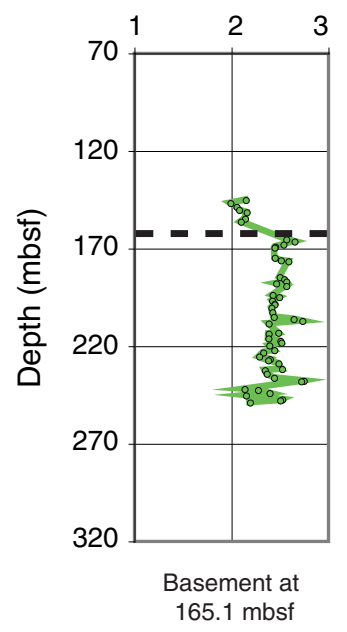

Site U1350

Bulk density $\left(\mathrm{g} / \mathrm{cm}^{3}\right)$

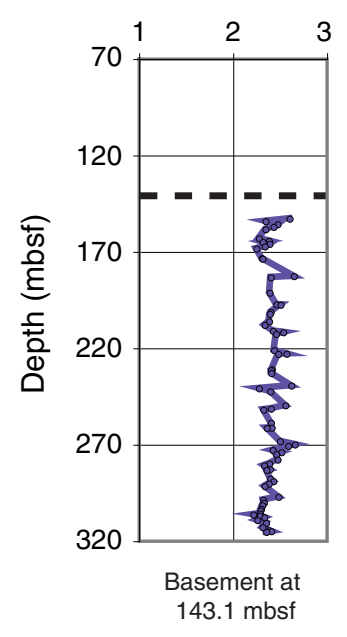


Figure F31. Potassium content results from downhole logging measurements in the upper basaltic basement sections of different localities.

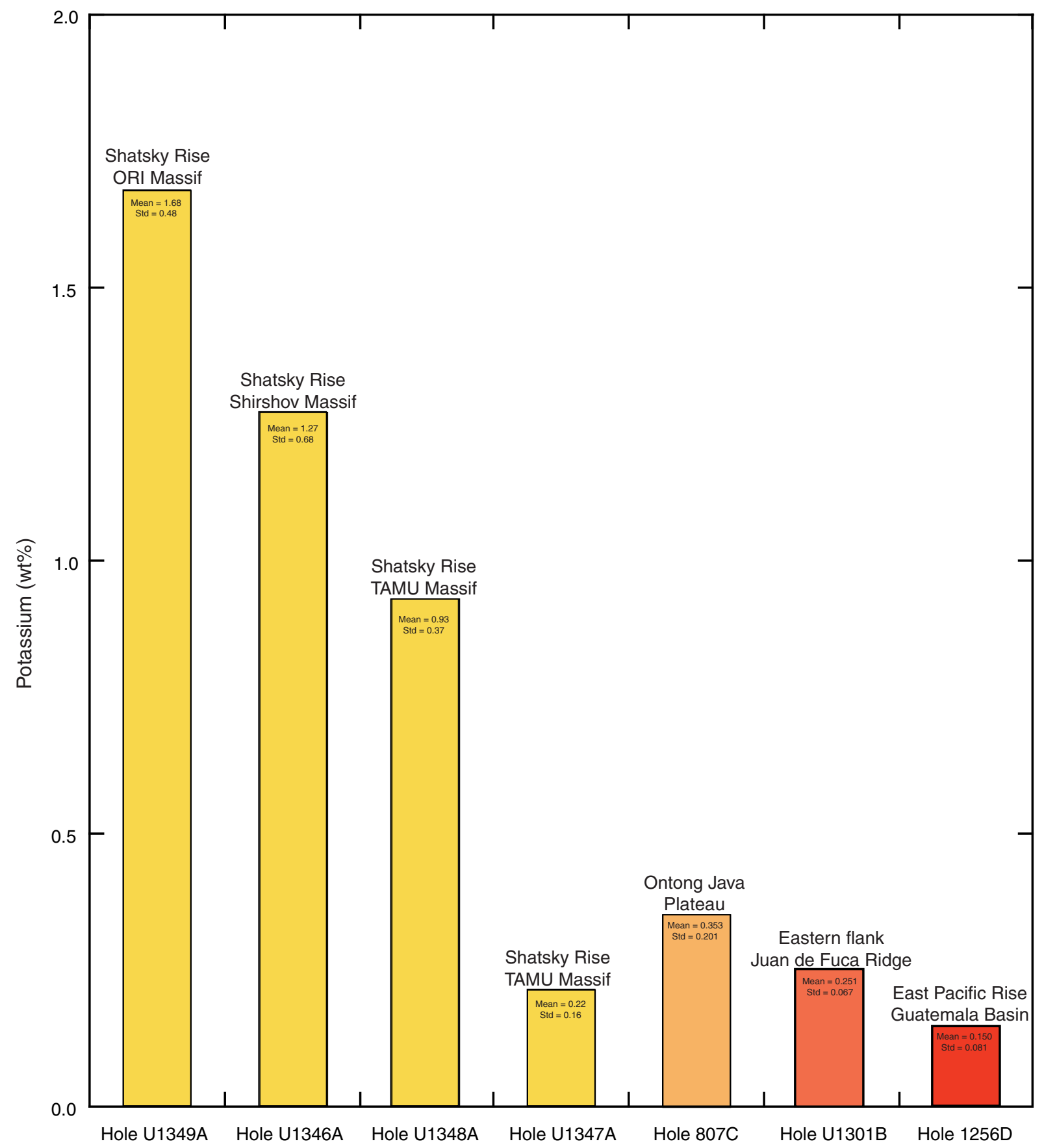


Table T1. Operations and hole statistics, Expedition 324.

\begin{tabular}{|c|c|c|c|c|c|c|c|c|c|c|c|c|c|}
\hline Hole & Latitude & Longitude & $\begin{array}{l}\text { Water } \\
\text { depth } \\
(\mathrm{m})\end{array}$ & $\begin{array}{c}\text { Total } \\
\text { depth } \\
\text { (m DSF) }\end{array}$ & $\begin{array}{c}\text { Time } \\
\text { in hole } \\
\text { (h) }\end{array}$ & $\begin{array}{l}\text { Cores } \\
(N)\end{array}$ & $\begin{array}{c}\text { Onset } \\
\text { of coring } \\
\text { ( } m \text { DSF) }\end{array}$ & $\begin{array}{l}\text { Cored } \\
(\mathrm{m})\end{array}$ & $\begin{array}{l}\text { Recovered } \\
\text { (m) }\end{array}$ & $\begin{array}{c}\text { Average } \\
\text { recovery } \\
\text { (\%) }\end{array}$ & $\begin{array}{l}\text { Igneous } \\
\text { basement } \\
\text { depth } \\
\text { (mbsf) }\end{array}$ & $\begin{array}{l}\text { Igneous } \\
\text { basement } \\
\text { cored } \\
(\mathrm{m})\end{array}$ & $\begin{array}{c}\text { Average } \\
\text { basement } \\
\text { recovery } \\
(\%)\end{array}$ \\
\hline U1346A & $38^{\circ} 00.401^{\prime} \mathrm{N}$ & $162^{\circ} 38.710^{\prime} \mathrm{E}$ & 3619 & 191.80 & 128.5 & 16 & 100.50 & 91.3 & 25.52 & 28.00 & 139.20 & 52.6 & 38.70 \\
\hline U1347A & $32^{\circ} 30.475^{\prime} \mathrm{N}$ & $159^{\circ} 14.078^{\prime} \mathrm{E}$ & 3450 & 317.50 & 250.5 & 29 & 71.00 & 246.5 & 116.10 & 47.10 & 157.60 & 159.9 & 64.20 \\
\hline U1348A & $34^{\circ} 24.940^{\prime} \mathrm{N}$ & $159^{\circ} 22.907^{\prime} \mathrm{E}$ & 3264 & 324.10 & 113.5 & 26 & 84.20 & 239.9 & 80.91 & 33.70 & & 0 & \\
\hline U1349A & $36^{\circ} 06.945^{\prime} \mathrm{N}$ & $158^{\circ} 27.527^{\prime} \mathrm{E}$ & 3127 & 250.40 & 126.8 & 16 & 116.00 & 134.4 & 65.87 & 49.00 & 165.10 & 85.3 & 67.40 \\
\hline U1350A & $36^{\circ} 04.491^{\prime} \mathrm{N}$ & $159^{\circ} 17.065^{\prime} \mathrm{E}$ & 4056 & 315.80 & 179.5 & 26 & 104.60 & 211.2 & 75.19 & 35.60 & 143.10 & 172.7 & 43.19 \\
\hline
\end{tabular}

Table T2. Definition of the downhole stratigraphic units, Expedition 324. (See table note.)

\begin{tabular}{|c|c|c|c|c|c|c|c|c|c|c|c|c|c|}
\hline \multicolumn{3}{|c|}{ Hole U1346A } & \multicolumn{3}{|c|}{ Hole U1347A } & \multicolumn{2}{|c|}{ Hole U1348A } & \multicolumn{3}{|c|}{ Hole U1349A } & \multicolumn{3}{|c|}{ Hole U1350A } \\
\hline Unit & $\begin{array}{l}\text { Depth interval } \\
\text { (mbsf) }\end{array}$ & $\begin{array}{l}\text { Lithologic } \\
\text { units }\end{array}$ & Unit & $\begin{array}{l}\text { Depth interval } \\
\text { (mbsf) }\end{array}$ & $\begin{array}{l}\text { Lithologic } \\
\text { units }\end{array}$ & Unit & $\begin{array}{l}\text { Depth interval } \\
\text { (mbsf) }\end{array}$ & Unit & $\begin{array}{l}\text { Depth interval } \\
\text { (mbsf) }\end{array}$ & $\begin{array}{l}\text { Lithologic } \\
\text { units }\end{array}$ & Unit & $\begin{array}{l}\text { Depth interval } \\
\text { (mbsf) }\end{array}$ & $\begin{array}{l}\text { Lithologic } \\
\text { units }\end{array}$ \\
\hline 1 & $100.5-110.1$ & $1-2$ & I & $71.0-80.6$ & 1 & I & $84.2-161.1$ & 1 & $116.0-135.3$ & 1 & I & $104.6-143.1$ & 1 \\
\hline II & 119.5-121.0 & $3-7$ & II & $80.6-99.8$ & 2 & II & $161.1-199.5$ & II & 135.3-144.9 & 2 & Ila & $143.1-212.8$ & $2-27$ \\
\hline III & $121.0-121.9$ & $8-10$ & III & $99.8-157.6$ & 3 & IIlla & $199.5-203.5$ & IIla & 144.9-156.1 & 3 & Illb & $212.8-240.2$ & $28-38$ \\
\hline IV & $122-139.2$ & $11-18$ & IV & $157.6-174.2$ & 4 & Illb & $203.5-209.0$ & Illb & $156.1-165.1$ & 3 & IIc & $240.2-290.4$ & $39-90$ \\
\hline \multirow[t]{12}{*}{ v } & 139.2-191.8 & $19-58$ & $\mathrm{~V}$ & 174.2-186.7 & 5 & IIIc & $209.0-242.0$ & IVa & $165.1-173.7$ & $4-12$ & III & $290.4-296.8$ & 91 \\
\hline & & & $\mathrm{VI}$ & 186.7-187.2 & 6 & IV & $242.0-262.8$ & $\mathrm{IVb}$ & 173.7-173.8 & 13 & IV & $296.8-315.8$ & $92-183$ \\
\hline & & & VII & $187.2-200.8$ & $7-9$ & $\mathrm{~V}$ & $262.8-287.0$ & IVc & $173.8-221.7$ & $14-31$ & & & \\
\hline & & & VIII & $200.8-205.8$ & 10 & $\mathrm{VI}$ & $287.0-324.1$ & $\mathrm{v}$ & $221.7-250.4$ & 32 & & & \\
\hline & & & IX & $205.8-217.5$ & 11 & & & & & & & & \\
\hline & & & $\mathrm{x}$ & $217.5-258.0$ & $12-42$ & & & & & & & & \\
\hline & & & $\mathrm{XI}$ & $258.0-258.6$ & $43-45$ & & & & & & & & \\
\hline & & & XII & $258.6-265.9$ & $46-52$ & & & & & & & & \\
\hline & & & XIII & $265.9-274.8$ & 53 & & & & & & & & \\
\hline & & & XIV & $274.8-292.2$ & $54-80$ & & & & & & & & \\
\hline & & & $x V$ & 292.2-314.6 & 81 & & & & & & & & \\
\hline & & & $\mathrm{XVI}$ & $314.6-317.5$ & 82 & & & & & & & & \\
\hline
\end{tabular}

Note: The top of Unit I for all holes is defined as onset of coring. 